$$
\text { UNIVERSIDADE DE SÃO PAULO }
$$

FACULDADE DE FILOSOFIA, LETRAS E CIÊNCIAS HUMANAS DEPARTAMENTO DE LINGUÍSTICA

PROGRAMA DE PÓS-GRADUAÇÃO EM SEMIÓTICA E LINGUÍSTICA GERAL

\title{
O Futuro do Subjuntivo em Orações Relativas no Português Brasileiro
}

Versão corrigida

São Paulo 


\section{LOMBADA}

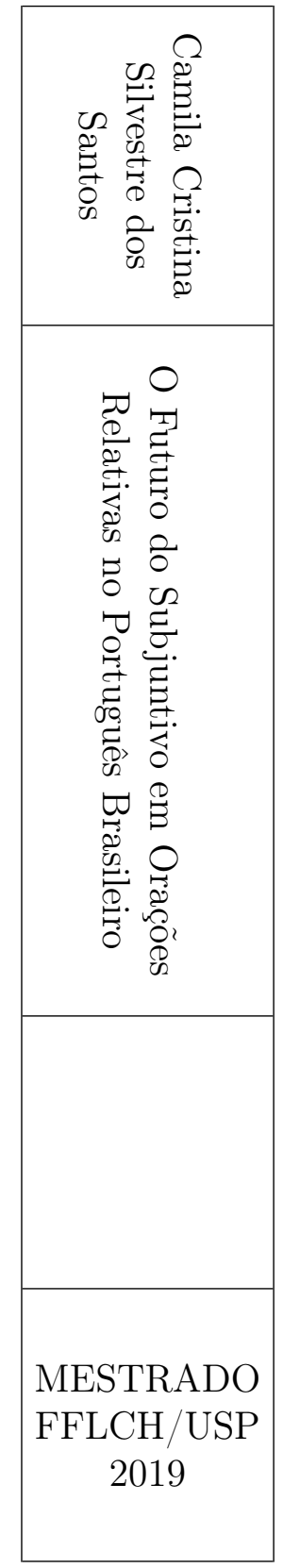




\title{
O Futuro do Subjuntivo em Orações Relativas no Português Brasileiro
}

\author{
Versão corrigida
}

Dissertação de mestrado apresentada ao Programa de Pós-graduação em Semiótica e Linguística Geral da Faculdade de Filosofia, Letras e Ciências Humanas da Universidade de São Paulo, como parte dos requisitos para obtenção do título de Mestre em Letras.

Orientador: Prof. Dr. Marcelo Barra Ferreira

São Paulo 
Autorizo a reprodução total ou parcial deste trabalho, por qualquer meio convencional ou eletrônico, para fins de estudo ou pesquisa, desde que citada a fonte.

Catalogação na publicação

Serviço de Biblioteca e Documentação

Faculdade de Filosofia, Letras e Ciências Humanas

SANTOS, Camila Cristina Silvestre dos

Sf

o futuro do subjuntivo em oraçōes relativas no português brasileiro / Camila Cristina Silvestre dos SANTOS ; orientador Marcelo Barra FERREIRA. - Săo Paulo, 2019.

$99 \mathrm{f}$.

Dissertação (Mestrado) - Faculdade de Filosofia, Letras e Ciếncias Humanas da Universidade de São Paulo. Departamento de Linguística. Área de concentração: Semiótica e Linguística Geral.

1. Modo. 2. Tempo. 3. Aspecto. 4. Subjuntivo. 5. Futuro. I. FERREIRA, Marcelo Barra, orient. II. Título. 
ENTREGA DO EXEMPLAR CORRIGIDO DA DISSERTAÇÃO/TESE Termo de Ciência e Concordância do (a) orientador (ạ).

Nome do (a) aluno (a): Camila Cristina Silvestre dos Santos

Data da defesa: 27/06/2019

Nome do Prof. (a) orientador (a): Prof. Dr. Marcelo Barra Ferreira

Nos termos da legislação vigente, declaro ESTAR CIENTE do conteúdo deste EXEMPLAR CORRIGIDO elaborado em atenção às sugestões dos membros da comissão Julgadora na sessão de defesa do trabalho, manifestando-me plenamente favorável ao seu encaminhamento e publicação no Portal Digital de Teses da USP.

São Paulo, 23/08/2019

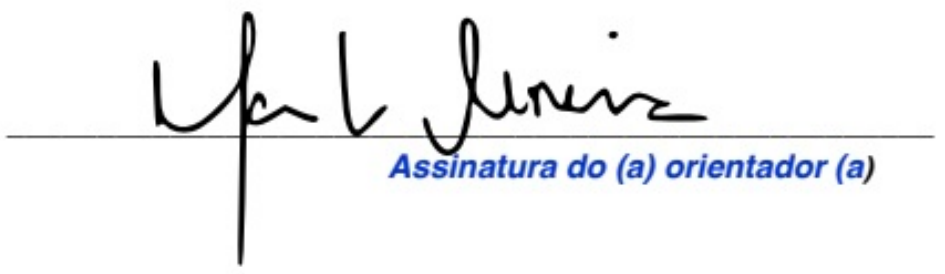


SANTOS, C. C. S. O Futuro do Subjuntivo em Orações Relativas no Português

Brasileiro. Dissertação apresentada à faculdade de Filosofia, Letras e Ciências Humanas da Universidade de São Paulo para obtenção do título de mestre em Letras.

Aprovada em: / /2019

\section{Banca examinadora}

Profa. Dra. Luciana Sanchez Mendes Julgamento:

Profa. Dra. Ana Paula Quadros Gomes Julgamento:

Profa. Dra. Ana Lúcia de Paula Muller Julgamento:

Profa. Dra. Fernanda Rosa Silva (suplente) Julgamento:

Assinatura:

Prof. Dr. Michel Platiny Assis Navarro (su- Instituição: IFSP plente)

Julgamento:

Prof. Dr. Marcos Lopes (suplente) Julgamento: Assinatura:

Instituição: UFF

Assinatura:

Instituição: UFRJ

Assinatura:

Instituição: USP

Assinatura:

Instituição: UFF

Instituição: USP

Assinatura: 


\section{AGRADECIMENTOS}

Ao meu orientador, Marcelo Ferreira, por guiar esta pesquisa desde o início com inspiração e (muita) paciência. Por estar sempre disponível e, em especial, por fazer desta uma experiência saudável, respeitosa e enriquecedora. Foram cerca de dois anos em que saí das nossas reuniões com a constante certeza de saber pouco ou quase nada e, curiosamente, com vontade de aprender sempre mais. Obrigada por ser o orientador com o qual todo estudante deveria ter a oportunidade de trabalhar.

Aos professores das matérias que fiz durante a pós-graduação, professora Elaine Grolla, professor Jairo Nunes, professora Janayna Carvalho, professor Marcelo Ferreira, por partilharem tempo e conhecimento preciosos com seus alunos.

Aos professores Luciana Sanchez Mendes e Marcos Lopes por participarem da minha banca de qualificação com apontamentos tão importantes para o prosseguimento das minhas investigações.

À professora Ana Laura Marques, da Universidade de Santiago do Chile, pelo convite para falar sobre meu trabalho aos seus alunos.

À professora Marta Donazzan, da Universidade de Nantes, pela recepção em sua universidade e pela oportunidade de apresentar esta pesquisa a um público tão interessado.

À Capes pelo financiamento desta pesquisa.

Aos colegas de pós, Tarcísio, Juliana, Raíssa e Marcela. À Jéssica, pelas aulas de LaTex, pelos jantares inusitados, pelo auxílio com prazos e burocracias, por passear com o Joaquino quando eu não pude (agradeço ao Ivan também!). À Ana Carolina, pelo incentivo que faltava para começar tudo isso.

Ao João e à Maria, que demitiram alguns funcionários, contrataram outros, compraram muitos peixes, escolheram candidatos, votaram e abriram portas.

Em dois anos de tantas mudanças e incertezas, quero agradecer também pelo pouco que foi constante.

Aos colegas e alunos do Instituto Aprenda2.

Ao Scott e à Laetitia, cujas dúvidas sempre guiaram as minhas, cuja curiosidade sempre instigou a minha própria.

Às amizades de quinze anos, de mais ou menos meia década ou de seis meses que, de alguma forma, contribuíram para que essas linhas fossem escritas. À Carol, que está sempre lá. À Bia, por tudo o que a vida acaba dando um jeito de nos permitir compartilhar. Ao Gerson, por acreditar mais do que eu, todas as vezes. À Thaísa, Thamiris, Carina e Fabi, por serem as irmãs que a vida me deu.

À família que é e à família que sabe ser. A quem apoia e quem acredita. À Laurinha e à Carol. Ao meu avô Emilio, que lia comigo. À minha avó Therezinha, em especial e acima de tudo. 
Agradeço também às pessoas que estavam e se foram, às que vieram e foram embora pouco tempo depois. Tudo foi ensinamento. A quem nunca nem pensou em partir, minha gratidão sincera e o meu amor. Seguimos aprendendo juntos. 
Da trovoada de depois de amanhã?

Tenho a certeza, mas a certeza é mentira.

Ter certeza é não estar vendo.

Depois de amanhã não há.

O que há é isto:

Um céu azul, um pouco baço, umas nuvens brancas no horizonte,

Com um retoque de sujo embaixo como se viesse negro depois,

Isto é o que hoje é,

E, como hoje por enquanto é tudo, isto é tudo. 


\section{RESUMO}

\section{SANTOS, C. C. S. O Futuro do Subjuntivo em Orações Relativas no Português}

Brasileiro. Dissertação (mestrado). Faculdade de Filosofia, Letras e Ciências Humanas. Universidade de São Paulo, 2019.

Este trabalho investiga o futuro subjuntivo em orações relativas restritivas no português brasileiro considerando noções de modo, tempo e aspecto. Partindo de Quer (1998, 2008), assumimos que o modo subjuntivo em orações relativas indica sempre uma leitura não-referencial/atributiva do antecedente e observamos que o futuro do subjuntivo nesse ambiente só é selecionado quando há alguma referência de futuro na matriz, como um verbo no futuro do presente ou um predicado intensional como querer. Para questões temporais, tomamos por base a teoria referencial de tempo de Partee (1993) e o conceito de tempo de tópico de Klein $(1994,2009)$ e propomos que o futuro do subjuntivo deve ser considerado um tempo referencial não-passado a) relacionado a um tempo de tópico evidente no contexto; b) concomitante ou posterior ao momento de fala; c) também concomitante ou anterior ao tempo da matriz, nunca posterior a ele. Abordamos as classes de aspecto lexical propostas por Vendler (1957) para investigar os contrastes entre presente e futuro do subjuntivo em orações relativas, duas formas subjuntivas que autores como Comrie e Holmback (1984) e Marques (2010) consideram competidoras entre si no sistema verbal do português. Concluímos que o contraste entre eles pode parecer pouco relevante a princípio, em especial em casos de predicados estativos, mas que ele se torna mais claro à medida em que se evidencia o tempo de tópico relacionado ao futuro do subjuntivo. Por último, com fins descritivos, voltamos nossa atenção a noções de aspecto gramatical, partindo da relação entre o tempo de situação e o tempo de tópico também proposta por Klein $(1994,2009)$ para definir o futuro do subjuntivo como um tempo referencial não-passado em que, em oposição aos tempos pretéritos do português, não há marcação morfológica de aspecto perfectivo ou imperfectivo.

Palavras chave: modo;tempo;aspecto;subjuntivo;futuro. 


\begin{abstract}
SANTOS, C. C. S. O Futuro do Subjuntivo em Orações Relativas no Português

Brasileiro. Dissertação (mestrado). Faculdade de Filosofia, Letras e Ciências Humanas. Universidade de São Paulo, 2019.

This work investigates the future subjunctive in relative restrictive clauses in Brazilian Portuguese considering notions of mood, tense and aspect. From Quer (1998, 2008) we assume that subjunctive mood in relative clauses indicates a non-referential / attributive reading of the antecedent. We also observe that the future subjunctive in this environment is only selected when there is some future reference in the matrix clause, as a verb in the simple future or an intensional predicate as to want. In discussing temporal features, we take Partee's (1993) referential theory of tense and the concept of topic time by Klein $(1994,2009)$ to propose that the future subjunctive should be considered a non-past referential tense a)related to a topic time highlighted in the context; b)concomitant or subsequent to the speech moment; c)also concomitant or prior to the time of the matrix clause. We approach the aspectual classes proposed by Vendler (1957) to investigate the contrasts between present and future subjunctive in relative clauses, two subjunctive forms that authors like Comrie and Holmback (1984) and Marques (2010) consider to be competitors in the Portuguese verbal system. We conclude that the contrast between them may seen little relevant at first, specially with stative predicates, but it becomes clearer if the topic time related to the future subjunctive is evidenced. At last, for descriptive purposes, we turn our attention to grammatical aspectual notions, considering the relation between the time of the situation and the topic time also proposed by Klein (1994, 2009), to define the future subjunctive as a non-past referential tense in which, in opposition to the past tenses in portuguese, there is no morphological marker of perfective or imperfective aspect.
\end{abstract}

Keywords: mood;tense;aspect;subjunctive;future. 


\section{Lista de figuras}

1.1 A bipartição do conceito de domínio. Adaptado de Vesterinen (2017) . . 8 


\section{Conteúdo}

$\begin{array}{ll}\text { Introdução } & 1\end{array}$

1 O futuro do subjuntivo em estudos anteriores $\quad 4$

1.1 Introdução . . . . . . . . . . . . . . . . . . . . . . . . 4

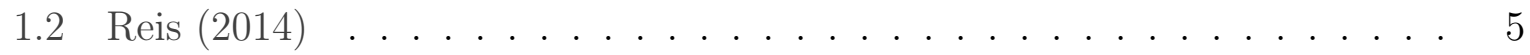

1.3 Vesterinen $(2017) \ldots \ldots \ldots \ldots \ldots \ldots$

1.4 Marques $(2010) \ldots \ldots \ldots \ldots \ldots \ldots$

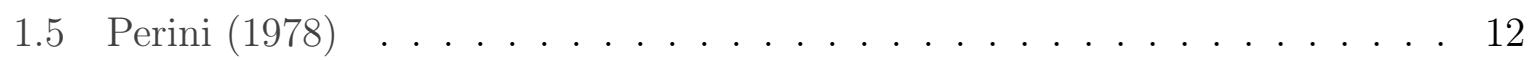

1.6 Comrie e Holmback (1984) . . . . . . . . . . . . . . . . . . . . 12

1.6.1 Caracterização temporal . . . . . . . . . . . . . . . 13

1.6.2 A definitude do futuro do subjuntivo . . . . . . . . . . . . . 16

1.7 Conclusão . . . . . . . . . . . . . . . . . . . . . . . 21

2 Modo 22

2.1 Introdução . . . . . . . . . . . . . . . . . . . . . . . . 22

2.2 A distribuição sintática do modo subjuntivo . . . . . . . . . . . . . . . 22

2.2.1 O modo subjuntivo em orações subjetivas . . . . . . . . . . . . . . 24

2.2.2 O modo subjuntivo em orações completivas . . . . . . . . . . . . . . . . . . . . . . . 25

2.2.3 O modo subjuntivo em orações adverbiais . . . . . . . . . . . . 26

2.2.4 O modo subjuntivo em orações relativas . . . . . . . . . . . . . . 27

2.3 Referencial teórico . . . . . . . . . . . . . . . . . . . . . 28

2.3.1 Portner (2018): um panorama . . . . . . . . . . . 28

2.3.2 Quer (1998, 2008): modelos de avaliação e tipos de subjuntivo . . . 31

2.4 O modo em orações relativas . . . . . . . . . . . . . . . . . 36

2.4.1 As características da oração relativa com subjuntivo . . . . . . . . . 36

2.4.2 O contraste entre indicativo e subjuntivo em orações relativas .. 38

2.5 O futuro do subjuntivo em orações relativas . . . . . . . . . . . . . . . 41

2.6 Conclusão . . . . . . . . . . . . . . . . . . . . . . . . 45

$\begin{array}{lll}3 & \text { Tempo } & 47\end{array}$

3.1 Introdução . . . . . . . . . . . . . . . . . . . . . . . . . 47 
3.2 A distribuição dos tempos do modo subjuntivo . . . . . . . . . . . . . . . . 48

3.3 Referencial teórico . . . . . . . . . . . . . . . . . . . 51

3.3.1 Klein (1994, 2009): tempo de fala (TU) e tempo de tópico (TT) . . 51

3.3.2 Partee (1973): As analogias entre pronomes e tempos verbais . . . . 53

3.4 O futuro do subjuntivo como um tempo referencial . . . . . . . . . . . . . 54

3.4.1 A relação entre o futuro do subjuntivo e o momento de fala . . . . . 55

3.4.2 A relação entre o futuro do subjuntivo e o tempo da matriz . . . . . 57

3.4.3 A restrição do futuro do subjuntivo . . . . . . . . . . . . . . . . 61

3.5 Conclusão . . . . . . . . . . . . . . . . . . . . . . 62

4 Aspecto $\quad 64$

4.1 Introdução . . . . . . . . . . . . . . . . . . . . . . . . 64

4.2 Referencial teórico . . . . . . . . . . . . . . . . . . 65

4.2.1 Aspecto gramatical: tempo da situação (Tsit) e tempo de tópico (TT) 65

4.2 .2 Aspecto lexical (Aktionsart) . . . . . . . . . . . . . 67

4.3 O futuro do subjuntivo e a leitura aspectual do predicado . . . . . . . . . . 69

4.3.1 O futuro do subjuntivo com predicados estativos . . . . . . . . . . 70

4.3.2 O futuro do subjuntivo com predicados não-estativos . . . . . . . . 72

4.3.3 O futuro do subjuntivo e o aspecto gramatical . . . . . . . . . . . 73

4.4 Conclusão . . . . . . . . . . . . . . . . . . . . . . 75

$\begin{array}{lll}5 & \text { Considerações finais e questões em aberto } & 77\end{array}$

$\begin{array}{ll}\text { Referências bibliográficas } & 79\end{array}$ 


\section{Introdução}

O modo subjuntivo tem recebido bastante atenção na literatura, em geral no que concerne sua distinção com o indicativo ${ }^{1}$. São pouco frequentes, no entanto, os estudos que abordam o subjuntivo em relação a questões temporais e aspectuais ${ }^{2}$, categorias que se mostram importantes para a análise de formas verbais. Neste trabalho, tendo em vista o objetivo de apresentar uma caracterização o mais abrangente possível acerca do futuro do subjuntivo em orações relativas, levaremos em consideração não apenas contrastes de modo, mas também de tempo e aspecto.

Modo típico de orações subordinadas, o padrão distribucional do modo subjuntivo é facilmente identificável, visto que quase sempre envolve a) seleção lexical por um predicado específico na oração matriz em contexto de orações completivas, como esperar em (1) ou b) uma conjunção na subordinada em contexto de orações adverbiais, como se em (2).

(1) João espera que Maria chegue cedo.

(2) Se Maria chegar cedo, João ficará feliz.

São três os tempos simples do modo subjuntivo em português brasileiro: passado, presente e futuro. Sua distribuição, no entanto, não é uniforme. Em orações completivas e adverbiais como as acima mencionadas, observamos o uso sem restrições do tempo passado do subjuntivo, como em (3a) e (4a). Nessas orações pode haver alternância de tempo (entre passado e presente em 3a e 3b e entre passado e futuro em $4 a$ e 4b) sob determinados ajustes (nas sentenças abaixo, por exemplo, a alteração também do tempo da matriz), os quais modificam de forma clara o significado da sentença:

\footnotetext{
${ }^{1}$ Para estudos sobre o subjuntivo em geral, ver Hooper (1975), Palmer (1986), Klein (1975, 1990), Quer (1998, 2008, 2009), Stowell (1993), Portner (1997). Para estudos sobre o subjuntivo em catalão, ver Quer (1998, 2008); em grego, ver Farkas (1992) e Giannakidou (1997), em francês, ver Yvon (1947), Grevisse (1969), Sato (1974), Moignet (1981) e Farkas (1992); em espanhol, ver Solano-Araya (1982), Bell (1990), Bybee e Terrell (1990) e Villalta (2008); em italiano, ver Saltarelli (1974), Portner (1993) e Giorgi e Pianesi (1997), em português europeu, ver Marques (1995, 2010).

${ }^{2}$ Algumas dessas pesquisas sobre o português brasileiro foram conduzidas por Perini (1978), Comrie e Holmback (1984), Reis (2014) e Vesterinen (2017). Os resultados serão detalhados e discutidos ao longo deste trabalho.
} 
(3) a. João queria que Maria chegasse cedo.

b. João quer que Maria chegue cedo.

(4) a. Quanto tivesse tempo, João estudaria.

b. Quando tiver tempo, João vai estudar.

A alternância temporal entre presente (5a e 6a) e futuro do subjuntivo (5b e 6b) nesses contextos não é possível, levando sempre à agramaticalidade:

(5) a. João quer que Maria compre um carro.

b. * João quer que Maria comprar um carro.

(6) a. * Quando tenha dinheiro, João vai comprar um carro.

b. Quando tiver tempo, João vai comprar um carro.

Outro ambiente em que se verifica a ocorrência do modo subjuntivo são as orações relativas restritivas, as quais configuram um caso à parte por duas razões que justificam sua escolha como nosso objeto de pesquisa. Em primeiro lugar, nesse contexto não há seleção lexical de modo. Além disso, pode haver não apenas alternância entre indicativo (7a) e subjuntivo (7b), como também entre presente (7b) e futuro (7c) do subjuntivo, diferentemente do que vimos com as orações completivas e adverbiais.

(7) a. João quer casar com uma mulher que tem muito dinheiro.

b. João quer casar com uma mulher que tenha muito dinheiro.

c. João quer casar com uma mulher que tiver muito dinheiro.

O uso ainda bastante produtivo do futuro no modo subjuntivo é algo que distingue o português das outras línguas românicas ${ }^{3}$. Entretanto, são poucos os trabalhos que se dedicam a ir além da descrição de padrões distribucionais para propor algum tipo de generalização a seu respeito, lacuna que buscamos ajudar a preencher com esta pesquisa. Os estudos específicos mais relevantes serão discutidos a seguir e a crítica as suas propostas irá delinear o caminho a ser trilhado em nossa análise do futuro do subjuntivo em relação às categorias verbais de tempo, aspecto e modo. Dentro da teoria referencial do tempo proposta por Partee (1973) e trabalhos subsequentes ${ }^{4}$, a proposta a ser detalhada nesta dissertação é a de que o futuro do subjuntivo é um tempo referencial não-passado,

\footnotetext{
${ }^{3}$ Conforme apontam Comrie e Holmback (1984) e Vesterinen (2017), o futuro do subjuntivo pode ocorrer também em espanhol, apesar de opcional e arcaico, restringindo-se nesse caso a determinados contextos, como textos jurídicos.

${ }^{4}$ Heim (1994), Von Stechow (1995), Abusch (1997), Kratzer (1998) e, em especial, Ferreira (2018)
} 
codificando concomitância ou posteridade em relação ao momento de fala, sem marcação morfológica de aspecto perfectivo ou imperfectivo.

Este trabalho se organiza da seguinte forma: no capítulo 1 veremos como o futuro do subjuntivo é tratado em gramáticas de referência e em estudos específicos, os quais muitas vezes se apoiam em sua distinção quanto ao presente do subjuntivo. O capítulo 2 é dedicado à exposição teórica relacionada ao modo em geral, analisando em particular a oposição entre indicativo e subjuntivo em orações relativas. O capítulo 3 destina-se à discussão de questões temporais que concernem o futuro do subjuntivo, apresentando a proposta de considerá-lo um tempo referencial não-passado. Por fim, o capítulo 4 discute noções de aspecto referentes ao futuro do subjuntivo, as quais nos parecem relevantes para a compreensão das questões apresentadas, sobretudo de seu contraste com o presente do subjuntivo. 


\section{Capítulo 1}

\section{O futuro do subjuntivo em estudos anteriores}

\subsection{Introdução}

Apesar de sua importância dentro do quadro geral de formas verbais do português, o futuro do subjuntivo não é objeto tão frequente de pesquisas, as quais, além disso, costumam apresentar determinados enfoques em detrimento de outros. Podemos encontrar descrições e análises do futuro do subjuntivo em trabalhos que tratam de subordinação em geral, aí citado apenas como exemplo ou parte da descrição do objeto ${ }^{1}$, bem como trabalhos mais específicos, esses voltados para a regularização de formas irregulares por falantes nativos (a exemplo de fizer/fazer; puser/pôr; vir/ver) ${ }^{2}$. Outros, ainda que se proponham a uma descrição bastante ampla, destacam em suas análises as orações adverbiais de tempo e condição, sob a justificativa de maior incidência de uso ${ }^{3}$.

Em gramáticas de referência, o futuro do subjuntivo costuma ser apresentado no quadro amplo de conjugação de tempos e modos. Mesmo assim, os exemplos específicos com futuro do subjuntivo são pouco frequentes. Em descrições de ambientes em que ele poderia ser usado, predominam exemplos de sentenças com verbos no indicativo ou no presente/passado do subjuntivo ${ }^{4}$.

Se os exemplos com futuro do subjuntivo são pouco utilizados, sua descrição específica é ainda menos recorrente. Há algumas tentativas, no entanto. Cegalla (2005) descreve os contextos de uso do futuro do subjuntivo (orações adverbiais condicionais, temporais e outras), fazendo menção ainda a sua forma composta, a qual, segundo ele, enuncia um fato futuro relacionado a outro fato também futuro, ou um fato passado, porém hipotético. De modo análogo, Mesquita (1999) explica que o futuro do subjuntivo exprime um fato

\footnotetext{
${ }^{1}$ Gryner (1990); Santos M. L. (2006); Santos R. M. A. (2005), Hirata-Vale (2008)

${ }^{2}$ Macedo (1980)

${ }^{3}$ Reis (2014), Perini (1978)

${ }^{4}$ Bechara (2009)
} 
que pode acontecer ou não, hipotético e eventual, sempre relacionado a outro fato. Ele também menciona a forma composta do futuro do subjuntivo, a qual indicaria um fato futuro com relação a outro fato também futuro.

Cunha e Cintra (2008) dedicam mais espaço ao futuro do subjuntivo, inclusive citando seu uso para além de orações subordinadas temporais, condicionais e relativas. Os autores descrevem que a forma simples marca uma eventualidade no futuro, enquanto a forma composta indica um fato futuro terminado em relação a outro fato também no futuro. Eles também pontuam que a oração principal da qual a subordinada depende deve ter um verbo no presente ou no futuro do indicativo. De forma geral, vemos que as gramáticas tradicionais tentam estabelecer uma descrição para o futuro do subjuntivo buscando sempre relacionar a situação que ele descreve a alguma outra, sem, no entanto, se ater à natureza dessa relação.

Perini (2017), por sua vez, em abordagem bastante diferente das demais, descreve o futuro do subjuntivo como uma forma complementar ao indicativo em orações adverbiais, não havendo razão para tratá-lo como uma forma subjuntiva nesses casos. Para ele, o futuro do subjuntivo deve ser analisado como uma forma subjuntiva de fato apenas em contextos de orações relativas, ambiente em que se comportaria de maneira análoga ao presente do subjuntivo. Essa proposta tem origem em um estudo anterior (Perini, 1978), mais bem detalhado na seção subsequente, na qual descreveremos brevemente esse e outros estudos específicos sobre o futuro do subjuntivo. Apesar de apresentarem-se sob enfoques e quadros teóricos diversos, é importante considerarmos os aportes destes estudos, apresentados aqui em ordem crescente de relevância para os nossos objetivos.

\subsection{Reis (2014)}

Baseando-se em dados extraídos de amostras de fala de setenta e dois informantes de Santa Catarina, Paraná e Rio Grande do Sul, a análise funcionalista ${ }^{5}$ de Reis descreve a distribuição do futuro do subjuntivo distinguindo seus usos voltados à expressão da modalidade daqueles cuja função se relaciona à expressão do tempo. Tomando como pressuposto que os valores de modalidade e temporalidade estão sempre presentes concomitantemente, mas com força ou graus distintos de expressão, Reis (2014) descreve que os padrões funcionais de uso do futuro do subjuntivo distribuem-se entre 'mais tempo (futuro) e menos modalidade' e 'menos tempo e mais modalidade':

Nos extremos do continuum, as principais forças atuantes são: (i) para o domínio mais temporal: a presença de fatores que reforçam a projeção futura e a ideia de predição no enunciado, como conector temporal,

\footnotetext{
${ }^{5}$ Ver Givón (1995; 2009); Bybee (1985); Bybee et al. (1994) e Fleischman (1982).
} 
tempo verbal futuro na oração principal, além de expressão da modalidade epistêmica de probabilidade e maior certeza do falante; (ii) para o domínio mais modal: a expressão da modalidade orientada ao agente, orientada ao falante e, sobretudo, da modalidade epistêmica de baixa certeza, assim como certos tipos de construções relativas, além da presença de dados em que o item verbal é de modalidade inerente ou modal.

(Reis, 2014)

No eixo da temporalidade, os valores temporais associados ao futuro do subjuntivo se distribuiriam entre tempo indeterminado (com maior força modal) (8), presente relativo (9), presente (10) e futuro $(11)^{6}$.

(8) Até eu me operar pra ficar bom se Deus quiser, vou ficar bom, se Deus quiser.

(9) E existem enfermeiras, enfermeiros e médicos e cada um tem o seu caráter. Às vezes eles estão nervosos demais com os problemas deles, seja lá o que for, e eles jogam pra os coitados dos doentes que aparecem lá moribundos.

(10) Se Deus for negro, se eles aceitam, por que que não vão aceitar os outros negros. São pessoas iguais umas às outras, são todas iguais.

(11) E agora onde é que nós vamos trabalhar? Só se ele aceitar nós de novo.

Segundo a autora, o presente relativo em (9) se diferencia do presente em (10) por ter expressão temporal fraca ou nula, de forma que sua referência temporal é o tempo do verbo da matriz. Quando comparados, os dados mostraram que o presente relativo é mais recorrente nas orações relativas do que nas adverbiais. No que se refere às relativas em si, os resultados apresentados indicam que o valor temporal é indeterminado em $53 \%$ dos casos analisados, mas pode ser também de presente relativo (27\%), presente (15\%) e futuro (10\%). Os exemplos apontados ao longo do trabalho de Reis (2014) para ilustrar os dados referentes à temporalidade não compreendem as orações relativas, talvez porque a autora tenha preferido priorizar exemplos de orações condicionais e temporais, uma vez que as relativas correspondem a apenas $13 \%$ da amostra total.

No eixo da modalidade, o futuro do subjuntivo ocorreria principalmente em enunciados marcados pela expressão da modalidade epistêmica, com destaque para presença dos traços modais de possibilidade (12) e probabilidade (13) nesses contextos.

\footnotetext{
${ }^{6}$ Os exemplos desta subseção são adaptados de Reis (2014)
} 
(12) Tirou o aumento de todo mundo, só vai dar aumento pro fim do de junho, se der, né? Se der.

(13) No caso quando ele tiver dezoito anos, quando ele entrar no quartel ele não entra daí como recruta, como soldado.

Acerca das orações relativas, a análise da autora descreve a função do futuro do subjuntivo como tipicamente modal, utilizado para marcar o modo irrealis. Esse modo indicaria a não assertividade do enunciado, o que a autora associa a diferentes atitudes do falante, como dúvida e incerteza (14), desejo (15) e sugestão (16).

(14) Então ele trazia vinte pães, trazia um potezinho de mel, um vidrinho, que seja lá o que for. Mas mel puro.

(15) Seja o que Deus quiser.

(16) Os temperinhos, quem quiser, assim, imediato que faz, já pode botar folhinha de salsa.

Ainda que a pesquisa de Reis (2014) forneça uma descrição funcional e distribucional bastante ampla acerca do futuro do subjuntivo, nada é falado sobre a distinção entre presente e futuro do subjuntivo em orações relativas e mesmo entre os futuro do subjuntivo e do indicativo, de forma que essa análise isolada do futuro nos instiga a avançar na investigação da problemática que propomos aqui.

\subsection{Vesterinen (2017)}

Sob o viés da gramática cognitiva ${ }^{7}$, Vesterinen (2017) se propõe a uma análise unificada para a semântica do subjuntivo em português. Para tanto, o autor baseia-se no conceito de domínio, o qual pode ser bipartido em dois: o domínio epistêmico e o domínio de controle específico.

O domínio epistêmico, evocado por predicados como acreditar (17a) e duvidar (17b) ${ }^{8}$, reflete, como o nome sugere, uma atitude epistêmica do conceptualizador em relação a um evento, correspondendo a sua concepção de realidade.

\footnotetext{
${ }^{7}$ Ver Langacker (1987, 1991, 1993, 2008, 2009) e Vesterinen (2010, 2012, 2013, 2014a, 2014b).

${ }^{8}$ Os exemplos desta subseção são adaptados de Vesterinen (2017)
} 


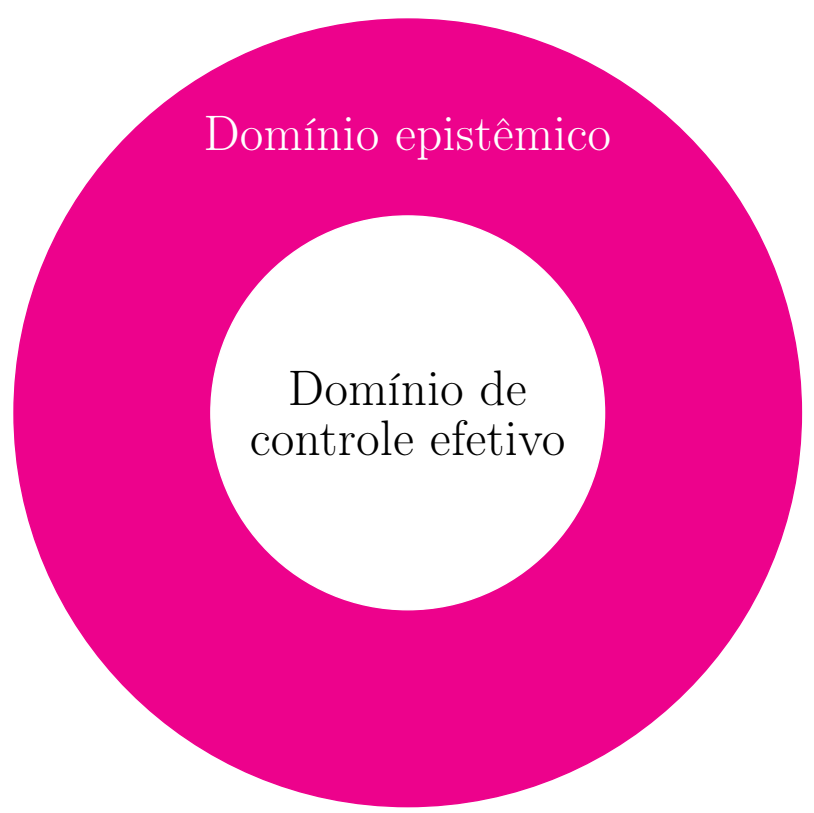

Figura 1.1: A bipartição do conceito de domínio. Adaptado de Vesterinen (2017)

(17) a. Acredito que Joana está brava com você.

b. Duvido que Pablo quer falar com você.

O domínio de controle efetivo, por sua vez, é aquele relacionado às intenções do conceptualizador em influenciar o que acontece ${ }^{9}$. Pode, por exemplo, designar a atitude emocional do conceptualizador em relação a um evento, expressar o desejo de que um evento se realize ou a tentativa de influenciar a sua realização. Nesses casos, o domínio de controle efetivo está relacionado, respectivamente, a expressões linguísticas como ser uma pena que (18a), querer que (18b) e à condição que (18c).

(18) a. É uma pena que não trabalhes mais.

b. Quero que me escutes.

c. À condição de que te portes bem, podes sair.

De acordo com Vesterinen (2017), o tipo de predicado (ou expressão linguística) determina o domínio relevante para a sentença, quer seja o epistêmico (no caso dos exemplos 17a e 17b), quer seja o de controle efetivo (como nos exemplos 18a, 18b e 18c). O autor assume que a escolha de modo, por sua vez, está relacionada à localização do evento descrito. O evento pode estar a) dentro do escopo do domínio relevante em caso de indicativo ou b) fora do escopo do domínio em questão em caso de sentenças com subjuntivo. Nas sentenças em (17), com indicativo, o domínio relevante é o domínio epistêmico do conceptualizador, dentro do qual está o evento descrito. Já nas sentenças em (18),

\footnotetext{
${ }^{9}$ Langacker, 2009
} 
com subjuntivo, o domínio relevante é o domínio de controle efetivo do conceptualizador. Nesses casos, no entanto, o participante ativo do evento descrito não é o próprio conceptualizador. Dessa forma, o evento é localizado fora do domínio relevante evocado. Em resumo, o subjuntivo evoca um determinado domínio, mas localiza o evento fora dele.

Para Vesterinen (2017), o conceito de domínio tem o potencial de uma explicação unificada para o modo subjuntivo em português, inclusive em orações relativas. Para esse tipo de oração, o domínio relevante é o domínio epistêmico do conceptualizador. Segundo o autor, oração relativas com subjuntivo descrevem sempre referentes desconhecidos, por isso localizados fora desse domínio. A alternância entre presente e futuro do subjuntivo, nesses casos, seria responsável apenas por contribuir com a localização temporal do evento em relação ao momento de fala, de maneira que a diferença entre essas duas formas seria relacionada ao tempo morfologicamente marcado.

Vesterinen (2017) descreve que em (19), por exemplo, o presente do subjuntivo não exclui a possibilidade de que já exista determinada política no momento presente, apenas indica que o falante não a conhece, ou seja, que se trata de um referente desconhecido. Em (20), o futuro do subjuntivo, por sua vez, designa um referente desconhecido com projeção futura (o logotipo da escola), uma vez que a escola ainda será selecionada.

(19) A solução só pode ser uma política que tenha em conta os factores de ordem natural, social e económica do território.

(20) Uma ligação grátis à Internet será o prémio para a escola que tiver o logótipo mais bonito.

Como veremos no transcorrer deste trabalho, no entanto, presente e futuro do subjuntivo podem apresentar a mesma referência temporal, algo não abordado pelo estudo de Vesterinen (2017), de forma que acreditamos que as diferenças e semelhanças entre esses dois tempos do subjuntivo podem ser melhor exploradas para uma descrição mais detalhada.

\subsection{Marques (2010)}

Marques (2010) apresenta três propostas que buscam descrever o significado da relação entre o modo subjuntivo e seus tempos simples (pretérito, presente e futuro). A primeira delas considera os tempos do subjuntivo como tempos anafóricos, dependentes do tempo da oração matriz (21), hipótese confrontada, segundo o autor, pelos fatos de a) o subjuntivo poder ocorrer em orações independentes (22) e b) nem sempre haver concordância de tempos entre a matriz e a encaixada $(23)^{10}$ :

\footnotetext{
${ }^{10}$ Os exemplos desta subseção são adaptados de Marques (2010)
} 
(21) O que eu mais quero é que ele acabe/*acabasse o curso.

(22) Talvez ele esteja/estivesse doente.

(23) Ele pediu que telefone.

A segunda hipótese apresentada por Marques (2010) descreve os tempos do subjuntivo como localizadores temporais, considerando que, conforme sugerem suas designações, a diferença entre as diversas formas estaria relacionada ao ponto de perspectiva temporal a elas associada: o pretérito imperfeito teria perspectiva temporal passada, o futuro teria perspectiva temporal futura, o presente teria como ponto de perspectiva temporal o tempo de enunciação. Contra essa proposta, o autor destaca que impõem-se casos como os que seguem, em que as formas se alternam sem que haja diferença evidente de interpretação temporal. Em (24), por exemplo, (24a) pode ter perspectiva temporal presente tanto quanto (24b).

(24) a. Com essa segurança, duvido que alguém consiga assaltar o edifício.

b. Com essa segurança, duvido que alguém conseguisse assaltar o edifício.

Os exemplos de (25) a (27), por sua vez, comparam presente e futuro do subjuntivo e mostram que ambos podem apresentar informação temporal idêntica, tendo o tempo de enunciação como perspectiva temporal. Em (25) e (26) a relação é de sobreposição com o tempo de enunciação, enquanto em (27) temos relação de posterioridade.

(25) a. Se souberes a resposta, é melhor dizeres já.

b. Caso saibas a resposta, é melhor dizeres já.

(26) a. Eles querem fotografar os navios que estiverem afundados no porto.

b. Eles querem fotografar um navio que esteja afundado no porto.

(27) a. Entrevista as pessoas que encontrares no caminho.

b. Entrevista uma pessoa que encontres pelo caminho.

Assim, contrariamente a Vesterinen (2017), Marques (2010) afirma que as diferenças entre presente e futuro do subjuntivo não são de natureza (exclusivamente) temporal. Para explicar essas diferenças, o autor propõe, a partir da semântica de mundos possíveis ${ }^{11}$, que as diversas formas de tempo do modo subjuntivo (passado, presente e futuro) devem

\footnotetext{
${ }^{11}$ Kratzer (1991), Portner (2009)
} 
ser consideradas operadores modais. Elas apontam para situações possíveis de serem consideradas e indicam que o estado das coisas descrito não se verifica em todas essas situações possíveis para a interpretação da sentença. Segundo o autor, presente e futuro do subjuntivo ambos impõem que as situações possíveis a se considerar sejam parte do context set e incluam o tempo de enunciação, restrições não aplicadas ao passado do subjuntivo. A diferença entre presente e futuro do subjuntivo, por sua vez, residiria no fato de este último fazer referência a situações possíveis apresentadas como parte de outras situações.

Baseando-se nos contextos de distribuição do futuro do subjuntivo, Marques (2010) argumenta, então, que ele só pode ocorre em contextos que envolvem quantificação universal, como orações introduzidas por se (28) e quando (29). Assim, em orações relativas, o futuro do subjuntivo também só seria gramatical em sentenças com um quantificador universal (30), ocorrendo em proposições que denotam partes de situações maiores. Em (29), por exemplo, as situações possíveis em que o enunciador está em casa são parte de situações em que ele deixa a luz acesa. O presente do subjuntivo estaria excluído desses contextos, podendo ocorrer em outros tipos de orações relativas, condicionais e temporais $^{12}$.

(28) Se eu encontrar a Ana, falo-lhe do assunto.

(29) Quando estiver em casa, deixo a luz acesa.

(30) Todos os carros que estiverem estacionados na rua podem ser rebocados.

No entanto, Marques (2010) admite que em orações relativas com quantificador universal o presente pode ser aceitável (31). Além disso, não fica claro o que determinaria a diferença, se ela existe, entre (32a) e (32b), as quais podem ser consideradas equivalentes.

(31) ?Todos os carros que estejam estacionados na rua podem ser rebocados.

(32) a. Se eu encontrar a Ana, falo-lhe do assunto.

b. Caso encontre a Ana, falo-lhe do assunto.

Assim, a distinção entre presente e futuro do subjuntivo proposta por Marques (2010) não nos parece suficiente para explicar seus contrastes, o que incita avanços nesse tema.

\footnotetext{
${ }^{12}$ Os contextos de distribuição dos tempos do subjuntivo serão retomados e melhor descritos no capítulo 2 .
} 


\subsection{Perini (1978)}

Na década de 70, Perini (1978) iniciou um estudo acerca da semântica e da sintaxe do futuro do subjuntivo em português brasileiro, dividindo-o em duas partes. Na primeira, investigou o uso do futuro do subjuntivo em contexto de subordinadas não-relativas, ou seja, adverbiais condicionais e temporais. A segunda parte do estudo, jamais realizada pelo autor, pretendia investigar o futuro do subjuntivo em contexto de subordinadas relativas, já partindo da premissa de que seu resultado na primeira metade do projeto não se aplicaria à segunda.

Em linhas gerais, Perini (1978) argumenta que o futuro do indicativo teria duas realizações morfológicas distintas (por exemplo, farei e fizer) a depender do ambiente. O papel subjuntivo seria o de preencher lacunas deixadas pelo indicativo em situações em que ele não pode ser usado, ou seja, em caso de orações adverbiais de tempo e condição. Nos exemplos abaixo, presente (33a) e passado (33b) do indicativo podem ocorrer, mas o futuro do indicativo (33c) é agramatical. É o futuro do subjuntivo (33d) quem ocupa essa posição ${ }^{13}$ :

(33) a. Quando eu saio, levo o guarda-chuva.

b. Quando eu saia, levava o guarda-chuva.

c. * Quando eu sairei, levarei o guarda-chuva.

d. Quando eu sair, levarei o guarda-chuva.

Em resumo, Perini (1978) considera que em (33d) o futuro do subjuntivo tem o mesmo significado que teria o futuro do indicativo caso ele fosse possível nessa sentença, não havendo, portanto, razão para tratar o futuro em (33d) como um verdadeiro tempo do subjuntivo. A conclusão do autor é de que o futuro do subjuntivo em orações condicionais e temporais seria, portanto, uma variante posicional do futuro do indicativo, agramatical nesses contextos. Assim, para Perini (1978), futuro do subjuntivo e do indicativo em orações não-relativas estariam em distribuição complementar. Como já citado, no entanto, o estudo não se estendeu a orações relativas, contexto em que a distribuição complementar entre indicativo e subjuntivo não se verifica, ensejando estudos mais específicos acerca dessa questão. Um estudo com essas características foi conduzido por Comrie e Holmback (1984). Devido a sua relevância, ele será discutido em detalhes em seção própria a seguir.

\subsection{Comrie e Holmback (1984)}

Comrie e Holmback (1984) refutam a conclusão de Perini (1978) acerca das orações adverbiais e incluem em seu trabalho também as orações relativas. O objetivo dos autores

\footnotetext{
${ }^{13}$ Os exemplos desta subseção são adaptados de Perini (1978)
} 
é o de propor uma análise precisa e unificada para o futuro do subjuntivo em português brasileiro em seus variados contextos de distribuição, buscando também caracterizar a natureza da oposição entre futuro e presente do subjuntivo. A conclusão dos autores é de que a diferença entre presente e futuro do subjuntivo não é relacionada ao tempo morfologicamente marcado no verbo, e sim à maior definitude expressa pelo futuro do subjuntivo. Em suma, os autores defendem que o futuro do subjuntivo indica sempre maior definitude a) da situação, em caso de orações adverbiais ou b) da classe de entidades a que se refere em caso de orações relativas. Essa proposta será detalhada a seguir.

\subsubsection{Caracterização temporal}

Em se tratando da caracterização temporal do futuro do subjuntivo, Comrie e Holmback (1984) destacam o que de maneira mais informal já havia sido explicitado em trabalhos anteriores $^{14}$ : o futuro do subjuntivo localiza uma situação em um ponto anterior ou simultâneo a um ponto de referência que, por sua vez, está localizado no futuro em relação ao momento de fala. Para introduzir o conceito de ponto de referência, os autores partem da terminologia proposta por Reichenbach (1947). Dentro desse quadro, os tempos básicos (ou absolutos) presente, passado e futuro são representados, respectivamente, como em (34), em que S é o momento presente e E é a situação a ser localizada no tempo:

(34) a. Presente E simultâneo a S

b. Passado E antes de S

c. Futuro E depois de S

Também é possível localizar uma situação em relação a um ponto de referência $R$, e, então, relacionar esse ponto de referência ao momento presente, o que Comrie (1985) denomina tempo absoluto-relativo, como em (35): a saída da família na oração principal estabelece um ponto de referência passado ao momento de fala, de forma que a situação de João almoçar pode ser localizada antes desse ponto de referência.

Quando João tinha comido, a família saiu.

O mesmo acontece com o futuro do subjuntivo em (36), com a diferença de que aqui a saída da família estabelece um ponto de referência futuro, a partir do qual a situação de João comer se localiza anteriormente (36a) ou simultaneamente (36b).

(36) a. Quando o José comer, a família vai sair.

b. Enquanto José estiver comendo, a família vai sair.

${ }^{14}$ Sten (1973), Perini (1978) 
Isso posto, Comrie e Holmback (1984) sugerem uma formalização da caracterização temporal do futuro do subjuntivo como a que segue (37), a partir da ideia geral de que a situação descrita pelo futuro do subjuntivo deve se localizar em um ponto anterior à situação descrita na oração principal, sendo essa situação, por sua vez, localizada no futuro em relação ao momento de fala:

(37) Futuro do subjuntivo

E antes de/simultâneo a $\mathrm{R}$ depois de $\mathrm{S}$

Apesar de apresentarem exemplos apenas de orações adverbiais para tratar da caracterização temporal do futuro do subjuntivo, Comrie e Holmback (1984) afirmam que essa proposta se estende a todos os contextos em que ele é utilizado, ou seja, não só a orações adverbiais como também a relativas. A caracterização proposta, de fato, descreve (apesar de não explicar) a restrição flagrante que se aplica ao futuro do subjuntivo: a situação E por ele descrita é sempre anterior ou concomitante a um ponto de referência $R$ no futuro, nunca posterior. Em (38a), isso significa dizer que a mulher com quem João vai se casar precisa já ter muito dinheiro antes ou no momento do casamento. Em comparação, o futuro do indicativo em (38b), por sua vez, não impõe restrições temporais que ordenem as situações dessa forma. A situação acontece no futuro em relação ao momento de fala, mas pode ser anterior, concomitante ou posterior à outra situação no futuro. Assim, em (38b) a mulher com João vai se casar pode ser rica já no momento do casamento, antes dele, ou pode obter muito dinheiro depois.

(38) a. João vai casar com a mulher que tiver muito dinheiro.

b. João vai casar com a mulher que vai ter muito dinheiro.

Assim, a proposta de caracterização do futuro do subjuntivo em (37) acertadamente evidencia a relação de anterioridade observada entre E e R. No entanto, a partir dessa definição, nada pode ser dito em específico acerca de relação entre E, a situação descrita pelo futuro do subjuntivo e S, o momento de fala, visto que essa relação não é direta, mas intermediada por R, o ponto de referência na oração principal. Em outras palavras, a formalização de Comrie e Holmback (1984) deixa claro que E deve acontecer antes ou simultaneamente a $\mathrm{R}$ e que $\mathrm{R}$ é posterior a $\mathrm{S}$, o que condiz com parte do significado do futuro do subjuntivo, mas nada diz acerca da ordenação entre E e S. Da forma como a caracterização em (37) foi proposta, todas as relações entre E e S seriam válidas: E antes de S (37), E simultâneo a S (38) e E depois de S (39). Se assim fosse, a preferência por uma ou interpretação deveria se dar por vias pragmáticas. 


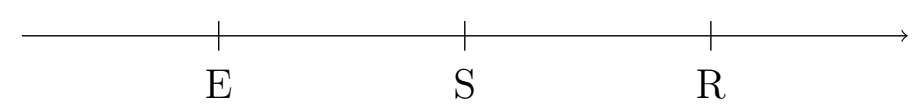

(40)

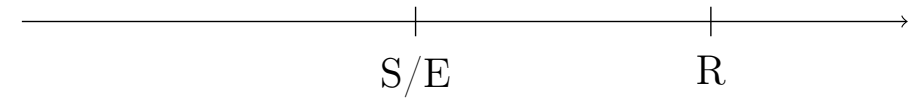

$(41)$

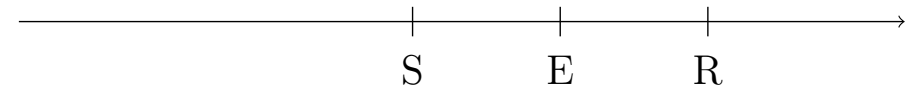

Vemos pelos exemplos, porém, que isso não se verifica. O futuro do subjuntivo descreve, invariavelmente a) uma situação anterior ou concomitante a uma situação que está no futuro em relação ao momento de fala, como já exposto, mas também b) uma situação concomitante ou posterior ao momento de fala como em (41) e (42), mas nunca anterior (40), parte do seu significado que a caracterização proposta por Comrie e Holmback (1984) falha em capturar. Seja em orações adverbiais (42), seja em relativas (43), essa condição é sempre atestada.

(42) Quando João terminar de comer, a família vai sair.

(43) João vai sair com a mulher que tiver muito dinheiro.

Em resumo, o que se apreende dos dados é que a situação descrita pelo futuro do subjuntivo $\left(S_{2}\right)$ é anterior (42) ou concomitante (43) à situação descrita na oração principal $\left(S_{1}\right)$, mas também está sempre ancorada ao momento de fala, seja indicando posteridade (42 e 43) ou concomitância (44) em relação a ele.

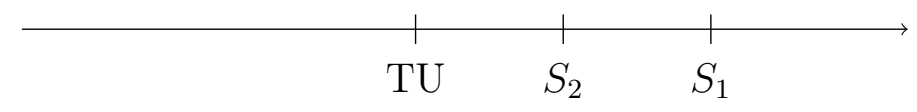


(45)

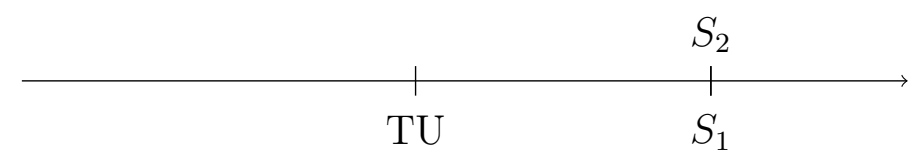

(46)

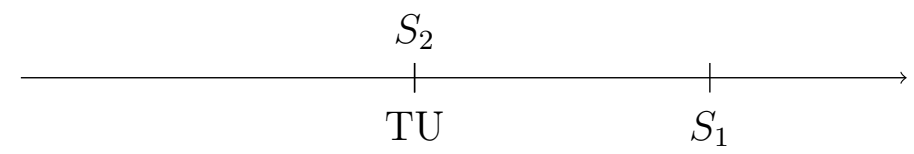

Dessa forma, qualquer generalização que venha a ser proposta a seu respeito deve ter essas relações evidenciadas. Voltaremos a essas questões no capítulo 3.

\subsubsection{A definitude do futuro do subjuntivo}

Conforme já citado, a proposta de Comrie e Holmback (1984) é a de que o futuro do subjuntivo deve ser considerado mais definido do que seu competidor no sistema verbal do português padrão, o presente do subjuntivo. Para defender essa hipótese em contexto de orações adverbiais, os autores recorrem ao contraste entre orações subordinadas introduzidas por antes que, a qual seleciona presente do subjuntivo (47a) e depois que, a qual seleciona futuro do subjuntivo (47b).

(47) a. Antes que João chegue, eu vou sair.

b. Depois que João chegar, eu vou sair.

Os autores argumentam que, em (47a), o presente do subjuntivo localiza a situação descrita na oração subordinada em um momento posterior e não casualmente dependente da situação descrita na oração principal. Em outras palavras, em (47a) o falante não se compromete com o valor de verdade da proposição, ou seja, ele não se compromete com a chegada de João. Em (47b), no entanto, o futuro do subjuntivo localiza a situação descrita em um momento anterior (ou simultâneo) e casualmente dependente da situação descrita na oração principal, havendo, então, o comprometimento do falante com a realização dessa situação. Para os autores, essa dependência caracteriza uma maior definitude do futuro do subjuntivo em comparação com o presente do subjuntivo.

Acreditamos, no entanto, que há evidências para se considerar que essa dependência entre a situação da oração subordinada e a da principal não se deve ao futuro do subjuntivo, mas talvez à conjunção utilizada. Podemos manter a noção de situações casualmente 
dependentes conservando a conjunção, mesmo quando há alternância entre o futuro do subjuntivo (48a) e o infinitivo (48b). A alternância entre o futuro do subjuntivo (48a) e o gerúndio (48c) também conserva a dependência entre as situações.

(48) a. Depois que João chegar, eu vou sair.

b. Depois de João chegar, eu vou sair.

c. Chegando o João, eu vou sair.

Em orações relativas, os autores alegam que a maior definitude do futuro do subjuntivo seria facilmente verificável no $\mathrm{DP} / \mathrm{NP}$ antecedente. Conforme eles argumentam, a interpretação de um NP que ocorre em contextos modais ou opacos pode ser ambígua entre referencial e não-referencial. Quando esse NP é modificado por uma oração relativa, a sua referencialidade é marcada pelo modo da oração subordinada: a oração relativa com indicativo (49a e 50a), em geral, marca a referencialidade do NP antecedente, enquanto o subjuntivo (49b e 50b) marca apenas a não-referencialidade ${ }^{15}$.

(49) a. João quer casar com uma mulher que tem muito dinheiro.

b. João quer casar com uma mulher que tenha muito dinheiro.

(50) a. João quer casar com a mulher que tem muito dinheiro.

b. João quer casar com a mulher que tiver muito dinheiro.

Comrie e Holmback (1984) assumem que casos de descrição indefinida com indicativo como o de (49a) acima, no entanto, podem ser ambíguos para uma leitura referencial ou não-referencial do antecedente, o que parece ir ao encontro da intuição de falantes nativos de português brasileiro. Assim, por sempre indicar a não-referencialidade do antecedente, o subjuntivo seria, ainda que não a única, a maneira mais favorecida de fazê-lo.

A diferença entre presente e futuro do subjuntivo residiria na definição desse antecedente: uma descrição não-referencial e indefinida do DP determinaria o uso do presente do subjuntivo, como em (51), (52) e (53), enquanto uma descrição não-referencial e definida levaria ao uso do futuro do subjuntivo, visto em (54), (55) e (56).

(51) a. José quer casar com uma mulher que tenha muito dinheiro.

b. * José quer casar com uma mulher que tiver muito dinheiro.

\footnotetext{
${ }^{15}$ Todos os exemplos desta subseção a partir deste ponto foram retirados de Comrie e Holmback (1984), conservando o julgamento de gramaticalidade dos autores, salvo quando apontado em contrário.
} 
(52) a. José vai casar com uma mulher que tenha muito dinheiro.

b. * José vai casar com uma mulher que tiver muito dinheiro.

(53) a. José sempre dança com uma mulher que tenha olhos azuis.

b. * José sempre dança com uma mulher que tiver olhos azuis.

(54) a. * José quer casar com a mulher que tenha muito dinheiro.

b. José quer casar com a mulher que tiver muito dinheiro.

(55) a. ? José vai casar com a mulher que tenha muito dinheiro.

b. José vai casar com a mulher que tiver muito dinheiro.

(56) a. * José sempre dança com a mulher que tenha olhos azuis.

b. José sempre dança com a mulher que tiver olhos azuis.

Pelos exemplos propostos pelos autores, o futuro do subjuntivo com descrições indefinidas é sempre agramatical, enquanto o presente do subjuntivo com descrições definidas varia de agramatical a pouco aceitável. A descrição indefinida de (51), (52) e (53) apontaria para um elemento de um grupo ou classe, qualquer que seja, ainda não determinado, ou seja, qualquer mulher com muito dinheiro (51 e 52) ou com olhos azuis (53), enquanto a descrição definida e não-referencial de (54), (55) e (56) indicaria uma leitura genérica do DP, de que não há uma mulher determinada e existente com quem José queira se casar (54), vá se casar (55) ou com quem ele dance (56), mas de que ela existirá ou de que José quer que ela exista.

Acreditamos que a divisão proposta por Comrie e Holmback (1984) até aqui não deve ser considerada de forma tão rígida, pois o presente do subjuntivo pode ser aceitável para uma descrição definida, assim como o futuro pode sê-lo para uma descrição indefinida. Tomando (57) como exemplo ilustrativo das sentenças com determinantes indefinidos, nos parece radical apontar (57b) como agramatical, ainda que (57a) pareça de fato mais aceitável. O mesmo pode ser dito de (58), exemplo com determinantes definidos: (58a) talvez pareça degradado em comparação com (58b), mas não completamente inaceitável.

(57) a. José quer casar com uma mulher que tenha muito dinheiro.

b. José quer casar com uma mulher que tiver muito dinheiro. 
(58) a. José sempre dança com a mulher que tenha olhos azuis.

b. José sempre dança com a mulher que tiver olhos azuis.

A análise de Comrie e Holmback (1984) se estende ainda a orações relativas cujos antecedentes são nomes nus. Segundo afirmam os autores, nomes nus (ou, em outras palavras, com artigo $\varnothing$ ) em português brasileiro são tradicionalmente vistos como um tipo de indefinido com interpretação não-referencial. Se a distribuição do artigo $\varnothing$ em antecedentes de orações relativas seguisse inteiramente o padrão descrito pelos autores para o artigo indefinido, ele deveria ser gramatical apenas com o presente do subjuntivo. No entanto, não é isso o que acontece. Comrie e Holmback (1984) argumentam que o artigo $\varnothing$, apesar de ter usualmente as características de um indefinido, pode anteceder também o futuro do subjuntivo em orações relativas.

Os dados apresentados pelos autores para demonstrar e explicar esse ponto são divididos entre NPs em posição de objeto e NPs em posição de sujeito. De acordo com a perspectiva dos autores para os dados selecionados, o NP com artigo $\varnothing$ em posição de sujeito pode ser antecedente de orações relativas com indicativo (59) e futuro do subjuntivo (61), mas seria agramatical ou pouco aceitável com o presente do subjuntivo (60).

(59) a. Mulher que é rica não tem que ser bonita.

b. Mulheres que são ricas não tem que ser bonitas.

(60) a. ? Mulher que seja rica não tem que ser bonita.

b. ? Mulheres que sejam ricas não tem que ser bonitas.

(61) a. Mulher que for não tem que ser bonita.

b. Mulheres que forem ricas não tem que ser bonitas.

A explicação dos autores para os dados acima é a de que, em exemplos como (61), o NP não-referencial é usualmente interpretado como genérico, referindo-se, no caso em questão, à classe de mulheres em geral, ou seja, à totalidade do conjunto de mulheres. Essa propriedade do NP genérico justificaria a presença do futuro do subjuntivo, associado pelos autores a descrições definidas, fazendo referência a uma entidade potencialmente identificável ou única ou a totalidade de um conjunto.

Em sentenças em que o NP está em posição de objeto, o artigo $\varnothing$ segue o padrão distribucional esperado, ou seja, o padrão do artigo indefinido. Assim, o NP com o artigo Ø é gramatical com o presente do indicativo (62) e o presente do subjuntivo (63) e agramatical com o futuro do subjuntivo (64). Nesse casos, o presente do subjuntivo ocorre porque a interpretação do NP sugere não a totalidade do conjunto de mulheres, mas um subconjunto arbitrário de elementos desse conjunto. 
(62) a. João gosta de mulher que é rica.

b. João gosta de mulheres que são ricas.

(63) a. João gosta de mulher que seja rica.

b. João gosta de mulheres que sejam ricas.

(64) a. * João gosta de mulher que for rica.

b. * João gosta de mulheres que forem ricas.

Analisando os dados mais detidamente, no entanto, a agramaticalidade do futuro do subjuntivo em (64) parece não estar relacionada à localização do NP antecedente em posição de objeto, e sim ao tipo de predicado na oração principal. Sob determinados ajustes, substituindo-se gostar por um predicado intensional como querer em (65), por exemplo, a sentença se torna aceitável.

(65) a. João quer sair com mulher que for rica.

b. João quer sair com mulheres que forem ricas.

A relação entre o predicado da oração principal e o futuro do subjuntivo na encaixada será retomada no capítulo 2. Por ora, observando-se essa alteração no predicado da matriz, verifica-se também que se alternarmos os nomes nus com NPs quantificados (66 e 67), os contrastes entre presente e futuro do subjuntivo parecem pouco ou nada marcados, esteja o NP em posição de sujeito ou de objeto:

(66) a. João quer sair com qualquer/alguma mulher que tenha muito dinheiro.

b. João quer sair com qualquer/alguma mulher que tiver muito dinheiro.

(67) a. Qualquer mulher que seja rica não tem que ser bonita.

b. Qualquer mulher que for rica não tem que ser bonita.

Apesar de o trabalho de Comrie e Holmback (1984) apresentar conclusões interessantes e facilmente atestáveis por meio da interpretação dada pelos autores ao quadro de sentenças analisadas, a conclusão a que chegamos é a de que não há interpretações tão categóricas nesse ambiente, ou, em outras palavras, de que a agramaticalidade das sentenças quando há alternância entre presente e futuro do subjuntivo em orações relativas não é de forma alguma tão evidente como nos casos de orações completivas (68) e adverbiais (69), em que, de fato, essa alternância não pode acontecer: 
(68) a. Espero que você termine os exercícios a tempo.

b. * Espero que você terminar os exercícios a tempo.

(69) a. * Quando você termine, apague a luz.

b. Quando você terminar, apague a luz.

Assim sendo, em caso de orações relativas, apenas a distinção entre os DPs não é suficiente para uma análise precisa dos dados. Se considerarmos que a diferença entre futuro e presente do subjuntivo reside apenas em uma maior definitude - ligada ao DP/NP antecedente - do primeiro em relação ao segundo, estaríamos ignorando outros elementos que se mostram relevantes para uma caracterização mais completa do futuro do subjuntivo, como questões relacionadas a modo, tempo e aspecto, as quais serão discutidas individualmente nos capítulos a seguir.

\subsection{Conclusão}

Nesse capítulo buscamos elencar estudos anteriores que tratam sobre o futuro do subjuntivo. Para Reis (2014), o futuro do subjuntivo em orações relativas tem função modal, com valor temporal predominantemente indeterminado. Vesterinen (2017), por sua vez considera que futuro do subjuntivo nesse contexto tem a função de contribuir com informação de tempo futuro. Perini (1978) desenvolve estudo com base em orações adverbiais e conclui que o futuro do subjuntivo é uma variante posicional do futuro do indicativo, sem, no entanto, estender sua análise a orações relativas. Marques (2010) compara presente e futuro do subjuntivo, defendendo que a diferença entre eles não é de natureza temporal, mas que está relacionada a seus contextos de distribuição: o futuro do subjuntivo, mais restrito, só pode ser usado em sentenças com um quantificador universal, fazendo referência a situações possíveis apresentadas como parte de outras situações. Comrie e Holmback (1984), por fim, também apontam que presente e futuro do subjuntivo não têm diferenças temporais entre eles, propondo que essas diferenças estão relacionadas, na verdade, à definitude do DP antecedente na oração matriz. O futuro do subjuntivo, considerado pelos autores como mais definido que o presente, seria usado em contextos de DP definido, enquanto o presente seria preferencialmente usado em contextos de DP indefinido. Uma análise mais apurada dos dados revelou que a distinção baseada na definitude do antecedente apenas não é suficiente para uma caracterização precisa do futuro do subjuntivo, de maneira que passaremos a discutir mais detalhadamente essa forma verbal em orações relativas considerando mais amplamente sua relação com o que diz respeito às categorias de modo, tempo e aspecto. 


\section{Capítulo 2}

\section{Modo}

\subsection{Introdução}

Tradicionalmente, distinguem-se três tipos de modo no sistema verbal do português, o indicativo, o subjuntivo e o imperativo, sendo o contraste entre os dois primeiros o que se põe em evidência neste capítulo. São várias as hipóteses que tentam explicar de maneira satisfatória e unificada as distinções e contrastes entre os modos indicativo e subjuntivo e, em diferentes graus, em que elas resultam. Apesar de as diferenças entre indicativo e subjuntivo não ser o foco desta pesquisa, é importante ao menos delimitarmos as consequências interpretativas decorrentes da escolha de modo. Tendo isso em vista, organizamos o restante deste capítulo da seguinte maneira. Na seção 2.2, verificaremos os ambientes de distribuição do modo subjuntivo em relação ao tipo de sentença em que ele se apresenta (orações subordinadas subjetivas, completivas, adverbiais e relativas). Na seção 2.3 sumarizamos em parte o recente trabalho de Portner (2018), o qual apresenta um panorama bastante elucidativo sobre as questões de contraste de modo. Ainda na seção 2.3 , detalhamos as propostas de Quer $(1998,2008)$ para a seleção de modo relacionada à modelos de avaliação e para a divisão do subjuntivo entre dois tipos distintos. A seção 2.4 é dedicada à descrição do subjuntivo em orações relativas, tratando ainda da relação ente indicativo e subjuntivo, sem nos atermos a questões temporais e aspectuais. Por fim, a seção 2.5 traz uma breve discussão acerca dos dados do português brasileiro, em especial de orações relativas com presente e futuro do subjuntivo, à luz das teorias explicitadas no capítulo.

\subsection{A distribuição sintática do modo subjuntivo}

Nesta seção apresentamos uma breve descrição dos padrões de distribuição do modo subjuntivo em português brasileiro, a fim de que possamos melhor situar o objeto deste trabalho. O modo indicativo pode ser encontrado em uma maior variedade de contextos, 
seja em orações principais (70a) ou subordinadas (70b), enquanto o subjuntivo, apesar de ocorrer em alguns tipos de orações principais, como (70c), é um modo típico de orações subordinadas subjetivas (70d), completivas (70e), adverbiais (70f) e relativas (70g), contextos nos quais pode ou não ocorrer também o modo indicativo e que serão brevemente explicitados a seguir.

(70) a. João vai comprar uma casa.

b. Maria disse que João vai comprar uma casa.

c. Talvez João compre uma casa.

d. É possível que João compre uma casa.

e. A Maria duvida que o João compre uma casa.

f. Se o João tivesse dinheiro, compraria uma casa.

g. O João quer comprar uma casa que tenha dois quartos.

Há estudos ${ }^{1}$ que apontam indícios de que o português brasileiro apresenta uma tendência à neutralização das formas subjuntivas em determinados contextos, quer pela sua substituição pelo indicativo (71), quer pela sua substituição por um complemento infinitivo (72 e 73$)$.

(71) a. Ele quer que eu faça isso até amanhã.

b. Ele quer que eu faço isso até amanhã.

(72) a. É importante que você faça isso até amanhã.

b. É importante você fazer isso amanhã.

(73) a. Ela pediu que você fizesse isso até amanhã.

b. Ela pediu para você fazer isso até amanhã.

Esses mesmos trabalhos indicam, no entanto, que essas particularidades demonstram apenas tendências quanto à distribuição de modo em português brasileiro, não sendo possível generalizá-las de forma categórica, uma vez que mesmo os falantes nativos apresentam variação quanto ao uso dos modos subjuntivo e indicativo nesses contextos. Além disso, sendo a alternância possível, é difícil determinar diferenças de significados entre os pares de sentenças acima. Em caso de orações relativas, por sua vez, a alternância entre indicativo e subjuntivo é bem estabelecida e resulta em diferenças interpretativas importantes, conforme será discutido mais adiante neste capítulo.

\footnotetext{
${ }^{1}$ Moreira Lima-Salles (2003), Pimpão (2012), Jesus (2014)
} 


\subsubsection{O modo subjuntivo em orações subjetivas}

Em orações subjetivas, o modo subjuntivo ocorre em caso de determinados predicados antecedentes, como ser lamentável, ser uma pena, ser possível, etc), a exemplo das sentenças em (74a) a (74e), mas também com predicados como convir (74f) e bastar (74g). Nesses casos, no entanto, apenas passado e presente do subjuntivo ocorrem; o futuro do subjuntivo em orações desse tipo é sempre agramatical.

(74) a. É lamentável que a Maria esteja doente.

b. É uma pena que a Maria tenha que ir ao hospital.

c. É possível que a Maria fique internada.

d. É importante que a Maria cuide da saúde.

e. É necessário que a Maria tome os remédios.

f. Convém que a Maria procure um médico.

g. Basta que a Maria faça o tratamento sugerido.

Nem todas as orações subjetivas, no entanto, prescindem de subjuntivo. Com expressões como ser claro (75a) e ser evidente (75b), por exemplo, temos a ocorrência do modo indicativo:

(75) a. É claro que a Maria está doente.

b. É evidente que a Maria está doente.

Tendo em vista os interesses deste trabalho, não nos deteremos neste momento em questões acerca da natureza da distinção entre expressões que requerem subjuntivo ou indicativo nesses contextos. Por ora, por motivação estritamente descritiva, nos interessa observar o fato de que os contextos que selecionam subjuntivo não selecionam o indicativo (76) e vice-versa (77), mas que o subjuntivo é licenciado se houver um operador de negação na matriz (78).

(76) a. *É importante que a Maria toma os remédios.

b. É importante que a Maria tome os remédios.

(77) a. É claro que a Maria está doente.

b. *É claro que a Maria esteja doente. 
(78) a. Não é claro que Maria esteja doente.

b. Não é evidente que a Maria esteja doente.

Isto posto, seguiremos com a simples descrição da distribuição sintática desses dois modos, passando agora às orações completivas.

\subsubsection{O modo subjuntivo em orações completivas}

Ainda que não seja este o foco desta pesquisa, entender, categoriza e explicar a distribuição do modo subjuntivo em contexto de orações completivas em geral tem sido objeto de grande variedade de trabalhos que lidam, de uma forma ou de outra, com distinções de modo ${ }^{2}$. Nesse ambiente, o subjuntivo é selecionado por um conjunto específico de predicados, como lamentar, duvidar, temer, querer, esperar, pedir recomendar, abaixo exemplificados. Aqui, em geral, não há alternância de modo; o modo indicativo leva à agramaticalidade:

(79) a. João lamenta que Maria esteja/*está doente.

b. João duvida que Maria esteja/*está doente.

c. João teme que a Maria esteja/*está doente.

d. João quer que Maria melhore/*melhora.

e. João espera que Maria melhore/*melhora.

f. João pediu que Maria fosse $/ *^{*}$ foi $/ *_{\text {ia }}$ ao médico.

g. João recomendou que a Maria fosse $/{ }^{*}$ foi $/ *^{*}$ ia ao médico.

A lista de exemplos acima não é exaustiva. Marques (1995) aponta ainda uma pluralidade de outros predicados que têm o subjuntivo em seu complemento: aborrecer, aconselhar, admirar, agradecer, aguardar, ansiar, apetecer, apreciar, atrapalhar, assustar, autorizar, causar, censurar, chatear, chocar, comover, compreender, consentir, convir, envergonhar, espantar, estranhar, evitar, exigir, gostar, impedir, implicar, incomodar, lastimar, mandar, motivar, negar, ordenar, originar, perceber, perdoar, permitir, preferir, preocupar, pretender, procurar, proibir, recear, requerer, revoltar, rogar, solicitar, sugerir, suplicar, surpreender, temer, tentar, transtornar, urgir.

Além de ser lexicalmente selecionado por determinados predicados, o subjuntivo em orações completivas pode ser também licenciado por um operador de negação, a depender do predicado constante na matriz (em presença de predicados como, por exemplo acreditar, pensar, presumir, supor, suspeitar, entre outros).

\footnotetext{
${ }^{2}$ Conforme referências citadas na introdução.
} 
(80) a. João não acreditava que Maria estivesse doente.

b. João não suspeitava que Maria estivesse doente.

c. João não pensava que Maria estivesse doente.

Em se tratando desses casos, é aceitável dizer que em português brasileiro pode haver também alternância entre indicativo e subjuntivo, mesmo quando não há operador de negação.

(81) a. João acreditava que Maria estava/estivesse doente.

b. João suspeitava que Maria estava/estivesse doente.

c. João pensava que Maria estava/estivesse doente.

Determinar a diferença de significado entre os pares de sentenças acima, se ela existe, foge ao escopo desta breve descrição distribucional. Importa ressaltar que, ainda que a alternância entre indicativo e subjuntivo seja possível aqui, ela é menos evidente e parece menos relevante do que a alternância que podemos observar em contextos de orações subordinadas adverbiais, as quais descreveremos a seguir.

\subsubsection{O modo subjuntivo em orações adverbiais}

As orações adverbiais são introduzidas por conjunções ou locuções conjuntivas, como se, quando, depois que, antes que, assim que, porque, até que, etc. Algumas delas selecionam o subjuntivo, como vemos nos exemplos em (82), casos em que o indicativo é agramatical. Outras, por sua vez, requerem o indicativo e não permitem o subjuntivo, como em (83):

(82) a. João vai trabalhar, mesmo que esteja/*está doente,

b. João vai abrir a porta do carro para que Maria entre/*entra.

(83) a. João correu tanto que se cansou $/{ }^{*}$ cansasse.

b. João estava cansado porque correu $/{ }^{*}$ corresse.

Algumas conjunções, no entanto, admitem tanto subjuntivo quanto indicativo, em especial em orações adverbiais temporais e condicionais. Nesses casos, no entanto, fica evidente que a ocorrência de indicativo ou subjuntivo não é definida apenas por uma ou outra conjunção, envolvendo também o tempo do verbo na oração principal. Vejamos as sentenças em (84) e (85), as quais exemplificam orações adverbiais temporais.

(84) a. O João almoçou quando chegou em casa.

b. * O João almoçou quando chegasse em casa. 
(85) a. * O João almoçaria quando chegou em casa.

b. O João almoçaria quando chegasse em casa.

Apesar de a conjunção quando ser licenciadora tanto de indicativo quanto de subjuntivo, eles não podem simplesmente alternar-se um com o outro nesse contexto. Como se pode verificar pela agramaticalidade de (84b), para que a sentença com subjuntivo seja possível, é necessário também que haja alteração no tempo do verbo da matriz, dos tradicionalmente chamados pretérito perfeito (almoçou) para o futuro do pretérito (almoçaria), como se vê em (85b). O mesmo se dá com orações adverbiais condicionais:

(86) a. Se o João estava em casa, ele atendeu o telefone.

b. * Se o João estivesse em casa, ele atendeu o telefone.

(87) a. * Se o João estava em casa, ele atenderia o telefone.

b. Se o João estivesse em casa, ele atenderia o telefone.

Assim como nos exemplos anteriores, a conjunção se em (86) e (87) não se mostra como condição única para a ocorrência de subjuntivo, a escolha de modo relacionando-se também com o tempo do verbo na matriz.

Até aqui, não exploramos a relação entre os tempos verbais e a distribuição sintática de modo em sentenças em que o subjuntivo ocorre, o que será feito no capítulo 3. Por ora, passaremos ao exame mais detalhado da distribuição do modo subjuntivo em orações subordinadas relativas, cerne deste trabalho.

\subsubsection{O modo subjuntivo em orações relativas}

Como exposto nas seções anteriores, o modo subjuntivo em subordinadas completivas (88) e adverbiais (89) está relacionado à seleção ou licenciamento por determinados predicados ou conjunções, como demonstram os exemplos abaixo retomados:

(88) João lamenta que Maria esteja doente.

(89) João vai trabalhar, mesmo que esteja doente.

Vimos também que, mesmo em casos de orações adverbiais em que há a possibilidade de alternância entre indicativo (90a) e subjuntivo (90b), diferenças relacionadas ao tempo do verbo na oração principal devem ser observadas para que as sentenças com um ou outro sejam gramaticais: 
(90) a. O João almoçou quando chegou em casa.

b. O João almoçaria quando chegasse em casa.

As orações relativas, por sua vez, tem uma característica particular. Nesse caso, indicativo (91a) e subjuntivo (91b) podem de fato se alternar. Além disso, o contraste de significado em sentenças do tipo de (90) é evidente, enquanto em sentenças como em (91) ele não parece tão óbvio. Em (91) não há alteração do tempo do verbo da oração principal como há em (90). A única diferença se dá, de fato, na alternância de modo na encaixada, entre um tempo pretérito do indicativo em (91a) e um tempo pretérito do subjuntivo em (91b).

(91) a. João queria alugar uma casa que tinha dois quartos.

b. João queria alugar uma casa que tivesse dois quartos.

Isso posto, interessa-nos investigar que fatores interferem ou mesmo estabelecem o uso do modo subjuntivo nesse tipo de oração encaixada, assim como identificar em que consistem as diferenças semânticas entre os modos indicativo e subjuntivo nesse contexto, questões que serão exploradas nas seções subsequentes.

Além disso, nosso interesse pelas orações relativas, não se dá apenas pela possibilidade de alternância de modo. Como já aventado na introdução, em português pode haver também variação de tempo na oração relativa - importando aqui a variação entre presente (92a) e futuro (92b) do subjuntivo -, sem a necessidade de qualquer alteração nas características da matriz.

(92) a. João quer sair com mulheres que tenham dinheiro.

b. João quer sair com mulheres que tiverem dinheiro.

De fato, as orações relativas são o único contexto em que presente e futuro do subjuntivo podem se alternar em ambientes idênticos, de forma que nos interessa também explorar as condições que contribuem para essa alternância e a diferença de significado dela decorrente, ao que retornaremos nos capítulos 3 e 4 .

A partir deste momento, uma vez descritos os ambientes de distribuição do modo subjuntivo, daremos prosseguimento à exposição dos trabalhos que se debruçaram sobre a questões de contraste de modo.

\subsection{Referencial teórico}

\subsubsection{Portner (2018): um panorama}

O recente trabalho de Portner (2018) coloca em perspectiva o estado atual dos estudos que lidam com distinções e contrastes entre os modos indicativo e subjuntivo, constituindo, 
portanto, um excelente ponto de partida para a compreensão de teorias relacionadas a esse tema.

Apesar de o subjuntivo ser encontrado em oposição ao indicativo também em contextos de orações adverbiais e relativas, Portner (2018) destaca que boa parte dos estudos sobre a seleção de modo concentra-se nos padrões de distribuição em orações completivas, de forma que é principalmente em torno desses dados que o autor formula sua síntese acerca dos estudos e teorias em voga.

Com base nessas sentenças, o autor apresenta uma divisão entre indicativo e subjuntivo a partir dos predicados que os selecionam. Essa distinção baseia-se, de maneira geral, na distribuição de modo em línguas românicas. Ela não ignora, no entanto, que mesmo nesses casos os padrões não são idênticos, e que indicativo e subjuntivo também podem contrastar em línguas como o grego e o alemão, por exemplo. Assim, salienta-se que a descrição abaixo é uma tentativa de generalização considerando os dados de forma abrangente. Um estudo mais pormenorizado deve levar em consideração, é claro, as particularidades de cada língua. Isso posto, o autor propõe a seguinte classificação.

(93) Predicados que selecionam indicativo:

a) Predicados de crença e conhecimento, como saber e acreditar.

b) Predicados de asserção, como dizer.

c) Predicados de ficção e criação mental, como imaginar e sonhar.

d) Predicados comissivos, como prometer.

e) Predicados de percepção, como ver, perceber e ouvir.

(94) Predicados que selecionam subjuntivo:

a) Contrapartes negativas de predicados de crença e conhecimento, como negar e duvidar.

b) Predicados de preferência, como querer e recear.

c) Predicados diretivos, como pedir e ordenar.

d) Predicados causativos, como fazer com que.

e) Predicados modais, como (ser)possível que e (ser)provável que.

Há, ainda, uma classe de predicados que pode selecionar tanto indicativo quanto subjuntivo, os predicados factivos. Portner (2018) divide-os em duas subcategorias.

(95) a) Predicados factivos neutros, como lembrar, selecionam indicativo. Acreditar e saber fazem parte dessa categoria também, apesar de serem analisados geralmente como predicados de crença/conhecimento.

b) Predicados emotivo-factivos, como (estar)feliz que, (ser)estranho que e lamentar, selecionam subjuntivo. 
Portner (2018) destaca que as principais teorias que tentam explicar o padrão de seleção dos modos indicativo e subjuntivo nesses contextos podem ser divididas em dois tipos, as que se baseiam em comparação e as que se baseiam na verdade da proposição, caracterizando-se da seguinte forma:

a) Teorias baseadas em comparação: conectam-se à ideia de que predicados avaliativos e emotivos selecionam subjuntivo, enquanto predicados intelectuais e cognitivos selecionam indicativo. Baseiam-se na premissa de que predicados com uma semântica comparativa, como os predicados diretivos e de preferência, selecionam subjuntivo, usando uma fonte de ordenação para ranquear a proposição expressa em relação a alternativas. Predicados que não tem uma semântica de comparação, por outro lado, como predicados de crença e conhecimento, de asserção, de ficção e criação mental e factivos neutros, selecionam indicativo. Portner (2018) salienta que determinados casos, no entanto, são mais difíceis de ser explicados por teorias dessa linha, como predicados que envolvem comparação, mas selecionam indicativo (os predicados comissivos e os predicados emotivo-factivos, esses últimos apresentando grande variação translinguística com respeito à seleção de modo) e predicados que não envolvem comparação, mas selecionam subjuntivo (predicados que são as contrapartes negativas de predicados de crença e conhecimento, como negar e duvidar, e predicados como acreditar, que selecionam subjuntivo em italiano). Destacam-se os trabalhos de Giorgi e Pianesi (1997), Villalta (2000, 2006, 2008) e Anand e Hacquard (2013).

b) Teorias baseadas na verdade do complemento: nesse caso, o indicativo é associado a contextos gramaticais que garantem a verdade da sentença em um mundo ou um conjunto de mundos, ao encontro da intuição de que o indicativo é usado para expressar a verdade, enquanto o subjuntivo é usado para outros objetivos. Essa distinção conecta-se à tradicional oposição entre realis e irrealis, o indicativo sendo a forma de marcação do primeiro e o subjuntivo, do segundo. Aqui, face ao desafio de justificar a seleção de indicativo por verbos como sonhar e imaginar, que não descrevem situações tidas como reais, Farkas (1992) sugere que a explicação para essa seleção deve levar em conta as noções de 'âncora extensional' e 'âncora intensional'. A proposta é que o indicativo é selecionado por verbos extensionais e o subjuntivo, por verbos intensionais. Uma proposição extensionalmente ancorada é aquela cujo valor de verdade é avaliado considerando-se o mundo real ou outro mundo possível. Uma proposição intesionalmente ancorada, por sua vez, não permite inferir que a proposição seja tida como verdadeira em um mundo em particular. Apesar de essa proposta adequar-se a predicados de ficção e criação mental, como sonhar e acreditar, há ainda a dificuldade em explicar a seleção de subjuntivo por predicados emotivo-factivos como lamentar, que introduzem uma proposição que pode ser inferida como verdadeira. Nessa linha, destacam-se os trabalhos de Huntley (1984) e Farkas (1992b), Giannakidou (1997, 1999, 2009, 2011, 2016), Giannakidou e Mari (2015), Quer (1998, 2008), Portner (1991) e Schlenker (2003, 2005, 2011). Dentre eles, evidenci- 
amos o trabalho de (Quer 1998, 2008), que se propõe a lidar com distinções de modo não apenas em orações completivas, mas também em outros contextos de distribuição do subjuntivo, como condicionais e relativas, sendo, por isso, particularmente interessante aos nossos propósitos. Tendo isso em vista, as propostas do autor serão melhor detalhadas nas seções a seguir.

\subsubsection{Quer $(1998,2008):$ modelos de avaliação e tipos de subjun- tivo}

O trabalho de Quer $(1998,2008)$ pretende desenvolver uma análise unificada para todos os ambientes de uso do subjuntivo, incluindo, portanto, o contexto de orações relativas, por vezes preterido em detrimento de outros, em especial o de orações completivas. A proposta de Quer $(1998,2008)$ pode ser dividida em dois pontos. Em princípio, o autor analisa a distinção entre os modos indicativo e subjuntivo, defendendo que a morfologia de modo assinala modelos distintos nos quais a sentença deve ser avaliada. Em seguida, para além da distinção entre modos, o autor argumenta a favor da divisão do subjuntivo em dois tipos diferentes marcados pela mesma morfologia: um subjuntivo intensional e outro de polaridade. Esses dois pontos serão detalhados nas seções a seguir.

\section{Modelos de avaliação}

A proposta de Quer $(1998,2008)$ deve ser entendida sob o viés de uma teoria dinâmica do significado, a qual incorpora à semântica certos aspectos de interpretação até então reservados à pragmática ${ }^{3}$. Em linha gerais, o autor assume que os enunciados são interpretados a partir de um background de contextos específicos. Um contexto c é definido como em (96), envolvendo parâmetros que incluem o commom ground $(\operatorname{cg}(c)$, a informação partilhada entre os agentes envolvidos no momento de fala), o context set w(c) (o conjunto de mundos compatível com a informação que já é parte do common ground, aquilo que os agentes ilocucionários acreditam ser verdade no momento da fala), o falante (s), o ouvinte (h), o mundo em que o enunciado é proferido (w0) e uma função que assinala valores a variáveis (f) ${ }^{4}$ :

(96) $\quad \mathrm{c}=<\mathrm{cg}(\mathrm{c}), \mathrm{W}(\mathrm{c}), \mathrm{s}, \mathrm{h}, \mathrm{w}, \mathrm{f} . .>$

A partir dessa definição, a noção de verdade de uma proposição deve ser avaliada relativamente a modelos de acordo com um contexto e a indivíduos. Modelos de indivíduos são definidos por Giannakidou (1998) como em $(97)^{5}$ :

\footnotetext{
${ }^{3}$ Ver Stalnaker (1978), Kamp (1981), Heim (1982, 1992), Kamp e Reyle (1993), Groenendijk e Stokhof, 1991), Chierchia (1995)

${ }^{4}$ Quer (1998) define o contexto seguindo Condoravdi (1994) e Giannakidou (1998)

${ }^{5} \mathrm{O}$ autor salienta que essa concepção de modelo corresponde essencialmente às noções de acessibilidade conhecidas a partir da lógica modal e da semântica de mundos possíveis.
} 
(97) seja $\mathrm{c}=<\mathrm{cg}(\mathrm{c}), \mathrm{W}(\mathrm{c}), \mathrm{s}, \mathrm{h}, \mathrm{w}, \mathrm{f} . . .>$ um contexto

um modelo $\mathrm{M}(\mathrm{x})$ em $\mathrm{M}$ é um conjunto de mundos em um contexto c associado a um indivíduo $\mathrm{x}$, em que $\mathrm{x}$ é a âncora individual.

Essas definições oferecem um caminho para a interpretação de orações completivas em que o subjuntivo é selecionado. Seguindo Farkas (1992) e as noções de âncora modal (o conjunto de mundos introduzido no contexto pelo predicado principal) e de ancoragem individual (uma relação que conecta mundos a indivíduos), Quer (1998) explica que a proposição denotada pelo complemento deve ser verdadeira de acordo com o indivíduo $\mathrm{x}$ sujeito da matriz (seja esse indivíduo o falante ou não). Isso é feito de maneira indireta, ancorando-se os mundos introduzidos pelo predicado a esse indivíduo. Assim, a variação entre indicativo e subjuntivo assinalaria uma mudança no tipo de modelo em que a proposição é avaliada, gerando contrastes interpretativos, de forma que o modo teria um impacto direto na interpretação da proposição.

Para asserções simples, a âncora individual é sempre o falante e o modelo default é o modelo epistêmico do falante, $\mathrm{ME}(\mathrm{s})$, representando a sua visão do mundo, aquilo em que ele/ela acredita. A sentença em $(98)^{6}$, por exemplo, deve ser avaliada em ME(s), modelo que representa o status epistêmico do falante.

\section{[João está feliz]ME(s)}

Predicados de atitude proposicional, por sua vez, introduzem tipos de modelos específicos no contexto. Para a análise desses predicados, Quer (1998, 2008) propõe uma divisão entre predicados intensionais fortes e fracos ${ }^{7}$. Predicados intensionais fracos, como acreditar, pensar, sonhar, imaginar, saber e prometer, entre outros, são aqueles que afetam o contexto à medida em que há comprometimento com a verdade do complemento ${ }^{8}$. Nesses casos, o modelo default também é o modelo epistêmico, seja ele ME(s) ou ME(x). Sentenças como (99), portanto, devem ser avaliadas em ME(Anna), o sujeito da matriz.

(99) Anna acredita [que pinguins voam]ME(Anna)

Com predicados intensionais fracos, mesmo que passemos do modelo epistêmico do falante para o modelo epistêmico de algum indivíduo, não há mudança no tipo de modelo, de forma que não há também alteração de modo e, consequentemente, não se atesta a ocorrência do subjuntivo. De acordo com isso, Quer $(1998,2008)$ toma o indicativo como o modo default, uma vez que esse modo é tipicamente usado tanto em asserções simples, quanto em encaixadas em casos em que não há alteração de modelo.

\footnotetext{
${ }^{6}$ Os exemplos desta subseção são adaptados de Quer (1998, 2008), traduzidos do catalão para o português

${ }^{7}$ Ver McCawley (1981) e Farkas (1992)

${ }^{8}$ Ver Farkas (1999) e Heim (1992)
} 
Predicados intensionais fortes, como querer, preferir e pedir, por sua vez, não afetariam o contexto da mesma forma que predicados intensionais fracos, uma vez que não há comprometimento com a verdade do seu complemento. Esses predicados introduzem o modelo de alternativas buléticas $\operatorname{MBul}(\mathrm{x})$, o qual conceptualiza mundos futuros mais desejáveis do que outros. Em outras palavras, mundos em que o complemento do predicado intensional se realiza são preferíveis àqueles em que isso não acontece.

(100) João prefere [que não lhe deem lição de casa]MBul(João)

Assim, (100) deve ser avaliada no modelo de alternativas buléticas de João, e não mais no modelo epistêmico $\mathrm{ME}(\mathrm{s}) /(\mathrm{x})$. A mudança no tipo de modelo é marcada pela mudança de modo no verbo da encaixada, ocorrendo, agora, o subjuntivo.

Em suma, Quer $(1998,2008)$ aponta que, de modo geral, predicados intensionais fracos selecionam indicativo, enquanto os predicados intensionais fortes selecionam subjuntivo. O autor argumenta que a seleção do modo subjuntivo por determinados predicados está diretamente ligada à mudança de modelo em que a proposição deve ser interpretada, do modelo epistêmico default para um modelo de alternativas buléticas. O papel do subjuntivo, então seria o de sinalizar a presença de um modelo de avaliação diferente do modelo default. Em (101), por exemplo, em que a verdade da proposição deve ser avaliada em um modelo epistêmico, o subjuntivo não é esperado:

(101) Anna acredita [que o João é louco]ME(Anna)

Em (102), no entanto, em que é introduzido um modelo de alternativas buléticas, o subjuntivo é selecionado:

(102) Anna quer [que João volte]MBul(Anna)

Com essas ferramentas, o autor pretende uma análise unificada para a seleção do modo subjuntivo em orações completivas. A concepção de modelos de avaliação aqui descrita também será retomada na seção 4.2, quando nos deteremos na questão das diferenças interpretativas entre indicativo e subjuntivo em orações relativas. Por ora, seguiremos com a descrição do trabalho de Quer $(1998,2008)$, voltando nossa atenção à divisão entre tipos de subjuntivo proposta pelo autor.

\section{Tipos de subjuntivo}

Para além da tentativa de propor uma análise unificada para a seleção de modo, Quer $(1998,2008)^{9}$ assume também a divisão entre um subjuntivo intensional e um subjuntivo de polaridade, cada um deles com propriedades bem definidas, as quais passamos

\footnotetext{
${ }^{9}$ Ver também Stowell (1993).
} 
a explicitar. O subjuntivo intensional é determinado por seleção lexical (em geral, por predicados volitivos, diretivos, causativos e implicativos). São quatro as propriedades que o identificam:

i. o subjuntivo intensional não alterna com o indicativo:

(103) Maria quer que João saia/*sai.

ii. ele não pode estar em orações encaixadas não imediatas à matriz:

(104) Maria quer que João diga que está/*esteja bem.

iii. ele apresenta efeitos de obviação do sujeito, ou seja, não pode haver correferência entre o sujeito da matriz e o da encaixada:

$(105){ }^{*} \mathrm{João}_{i}$ quer que $\operatorname{pro}_{i}$ vença a corrida.

iv. e, por fim, ele impõe restrições quanto à sequência de tempo, uma vez que a estrutura PRESENTE[PASSADO] não é possível:

(106) * João quer [PRESENTE] que Maria estivesse [PASSADO] em casa.

O subjuntivo de polaridade, por sua vez, é aquele licenciado por um operador, como os operadores interrogativos e de negação. É oposto ao subjuntivo intensional em todos os quatro critérios que o identificam:

i. o subjuntivo de polaridade pode ser alternar com o indicativo:

(107) Maria não acredita que João está/esteja doente.

ii. ele também pode ser licenciado em orações subordinadas consecutivas, ou seja, não imediatas à matriz:

(108) João não acredita que pensemos que ele tenha razão.

iii. não apresenta efeitos de obviação de sujeito, ou seja, pode haver correferência entre o sujeito da matriz e o da encaixada:

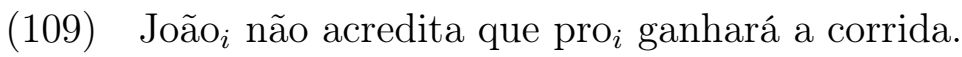


iv. e também não há restrições quanto à estrutura PRESENTE[PASSADO]:

(109) João não acredita[PRESENTE] que Maria estivesse[PASSADO] em casa.

Como veremos a seguir, a proposta de Quer (1998) é a de que o subjuntivo em orações relativas não é lexicalmente selecionado como um subjuntivo intensional, mas licenciado por predicados intensionais fortes ou determinados operadores, como um subjuntivo de polaridade. Dessa forma, Quer (1998) afirma que, em um quadro geral, são as propriedades do subjuntivo de polaridade que emergem em contexto de orações relativas ${ }^{10}$, ainda que a dependência da relativa em relação ao elemento que licencia o subjuntivo seja mediada pelo seu DP antecedente. Assim, o subjuntivo em orações relativas não tem restrições de sequência de tempo (110), não apresenta efeitos de obviação de sujeito (111), pode estar na encaixada não imediatamente subsequente à matriz (112) e pode alternar com o indicativo $(113)^{11}$.

(110) Pedro não edita os textos que ele tenha traduzido.

(111) João ${ }_{i}$ não dá nenhuma aula que ele $_{i / j}$ não tenha preparado com antecedência.

(112) Maria não tem amigos que façam piadas que sejam insensíveis.

(113) Estamos procurando um intérprete que saiba/sabe Oromo.

Além do licenciamento por um predicado intensional forte ou um operador na matriz, há outras condições relacionadas ao uso do subjuntivo em orações relativas. Ainda nos baseando no trabalho de Quer $(1998,2008)$, são essas condições que passaremos a detalhar na seção subsequente.

\footnotetext{
${ }^{10} \mathrm{O}$ autor não ignora, no entanto, que as propriedades do subjuntivo intensional podem ser verificadas em algumas orações relativas, especificamente em caso de orações finais. Nesse contexto, pode haver restrição de tempo PRESENTE[PASSADO] (a), efeitos de obviação de sujeito (b) e a impossibilidade de o subjuntivo estar na encaixada não imediata à matriz (c). Para mais detalhes, ver Quer (1998, 2008), capítulo 3 , seção 2.1 .

a. *Ela está procurando um namorado que lhe comprasse um iate.

b. ${ }^{*}$ pro $_{i}$ Está procurando um namorado que $\operatorname{pro}_{i}$ não traia.

c. *Ela está procurando um namorado que pense que ela seja fiel.

${ }^{11}$ Exemplos adaptados de Quer (1998).
} 


\subsection{O modo em orações relativas}

Nesta seção, descrevemos as propriedades relacionadas ao uso do subjuntivo em orações relativas atentando-nos para o fato de que elas não excluem a ocorrência do indicativo nesse mesmo contexto. Ainda sem nos atermos a questões temporais, discutiremos também as consequências interpretativas decorrentes da variação entre indicativo e subjuntivo nesse ambiente.

\subsubsection{As características da oração relativa com subjuntivo}

Segundo Quer $(1998,2008)$ são quatro as características que devem ser observadas na matriz para que o subjuntivo seja legitimado na relativa. Em primeiro lugar, o subjuntivo só pode ocorrer em orações relativas restritivas (114). Uma relação restritiva contribui com informação relevante sobre o DP/NP antecedente, restringindo-o ou especificando-o. Em orações relativas apositivas (115), o subjuntivo é sempre agramatical (115b) ${ }^{12}$. Nesses casos, somente o indicativo é viável $(115 \mathrm{a})^{13}$.

(114) João queria comprar um carro que tivesse quatro portas.

(115) a. João queria comprar um carro, que tinha quatro portas.

b. * João queria comprar um carro, que tivesse quatro portas.

O segundo ponto importante, já brevemente mencionado, é que, não havendo seleção lexical, o subjuntivo em orações relativas restritivas é licenciado apenas quando há certos ambientes na oração matriz, chamados pelo autor de intensionais: na presença de predicados intensionais fortes (116a), como querer e preferir ${ }^{14}$, tempo futuro (116b), operadores de negação (116c) e orações interrogativas (116d), condicionais (116e) e imperativas (116f). A alternância com o indicativo, ainda que não seja livre ou opcional e potencialmente ocasione diferenças de significado, é possível em todos esses contextos.

(116) a. João quer comprar uma casa que o agrade/agrada.

b. João vai comprar uma casa que o agrade/agrada.

c. João não viu nenhuma casa que o agradasse/agradou.

d. O João viu alguma casa que o agradasse/agradou?

\footnotetext{
${ }^{12}$ No entanto, se a relativa opositiva contar com um elemento que licencie subjuntivo, a sentença parece se tornar aceitável:

a) João queria comprar um carro, que talvez tivesse quatro portas.

${ }^{13}$ Os exemplos de Quer $(1998,2008)$ nesta subseção foram adaptados para dados do português.

${ }^{14}$ Como já definido na seção 3.2.1, em caso de predicados intensionais fortes não há comprometimento com a verdade do seu complemento.
} 
e. Se o João encontrar uma casa que o agrade/agrada, ele vai comprar.

f. Compre uma casa que te agrade/agrada.

Em terceiro lugar, Quer $(1998,2008)$ aponta que o subjuntivo está excluído em caso de matriz episódica (117b), contexto que não exclui o indicativo (117a).

(117) a. Maria comprou um par de sapatos que custou uma fortuna.

b. * Maria comprou um par de sapatos que custasse uma fortuna.

Interessante notar que o subjuntivo é possível se tivermos uma matriz episódica futura (118). Assim, essa condição parece, na verdade, apenas uma restrição das condições apontadas logo acima, as quais indicam as especificidades da matriz para que o subjuntivo seja possível na encaixada.

(118) Maria vai comprar um par de sapatos que custe uma fortuna.

Em quarto lugar, não há restrição quanto ao tipo de DP/NP que antecede a oração relativa com subjuntivo, seja ele um DP definido (119a) ou indefinido (119b), um nome nu (119c) ou um quantificador (119d e 119e). Mais uma vez, vemos que a alternância com o indicativo é lícita em todos os casos.

(119) a. João queria comprar o carro que tivesse/tinha quatro portas.

b. João queria comprar um carro que tivesse/tinha quatro portas.

c. João queria comprar carros que tivessem/tinha quatro portas.

d. João queria comprar qualquer carro que tivesse/tinha quatro portas.

e. João queria comprar algum carro que tivesse/tinha quatro portas.

Os DPs com demonstrativos (120), no entanto, constituem uma exceção:

(120) a. João queria comprar esse carro que tinha quatro portas.

b. * João queria comprar esse carro que tivesse quatro portas.

Essa exceção é justificável porque, conforme será melhor explicitado nas seções subsequentes, orações relativas com subjuntivo indicam sempre uma interpretação atributiva do elemento que a antecede, aquela que não se refere a um único objeto, mas a objetos possivelmente distintos em um conjunto de mundos possíveis. As sentenças de (119a) a (119e), por exemplo, referem-se a um carro ainda não específico, não concreto, apenas descrito como tendo quatro portas. Em (120b), no entanto, a leitura atributiva não está disponível para o DP com demonstrativo, uma vez que esse tipo de DP aponta para um carro existente no contexto de fala, tornando a sentença com subjuntivo agramatical. A 
partir deste momento, para focarmos nos objetivos específicos desta pesquisa, vamos nos restringir a lidar apenas com os contextos de predicados intensionais fortes (121) e de tempo futuro (122) na oração matriz, uma vez que o futuro do subjuntivo em orações relativas prescinde de um predicado orientado para o futuro para ser licenciado, com ou sem a presença de um operador de negação (em outras palavras, a negação apenas não é suficiente para licenciar o futuro do subjuntivo em orações relativas como acontece com as formas de presente e pretérito do subjuntivo).

(121) João quer/não quer comprar uma casa que tenha cinco quartos.

(122) João vai/não vai comprar uma casa que tenha cinco quartos.

Como ficou evidente, os quatro fatores acima apontados constituem condições obrigatórias para que o subjuntivo seja possível em orações relativas, mas não excluem o indicativo de nenhum desses contextos. Sendo esta alternância possível, passaremos agora a discutir quais são suas consequências em termos de significado.

\subsubsection{O contraste entre indicativo e subjuntivo em orações rela- tivas}

A alternância entre indicativo e subjuntivo em orações relativas é flagrante, conforme podemos verificar retomando exemplos da seção anterior.

(123) a. João quer comprar uma casa que tem cinco quartos.

b. João quer comprar uma casa que tenha cinco quartos.

(124) a. João vai comprar uma casa que tem cinco quartos.

b. João vai comprar uma casa que tenha cinco quartos.

O contraste de significado entre os pares de sentença, no entanto, não é tão evidente. Intuitivamente, poderíamos dizer que as sentenças em (123a) e (124a) referem-se a uma casa específica, concreta e já determinada no contexto de fala. As sentenças em (123b) e (124b), por sua vez, fariam referência a uma casa não específica, ainda a ser determinada, apenas idealmente descrita. Há também a impressão de que as sentenças com indicativo poderiam ser ambíguas para as duas leituras. Veremos a seguir como alguns autores tratam essa questão especificamente em relação ao dados do português, assim como também uma proposta mais abrangente, que tenta dar conta dessa potencial ambiguidade. 


\section{A (não)referencialidade do antecedente (Perini, 2017; Marques, 1995; Comrie e Holmback, 1984)}

Para Perini (2017), indicativo e subjuntivo em sentenças como as abaixo retomadas fazem, respectivamente, diferença entre elementos referenciais, tomados como existentes, e elementos não-referenciais, não necessariamente existentes, mas admitidos como possíveis. Assim, em (125a), o falante faz referência a uma casa existente, enquanto em (125b) o falante não se compromete com a existência da casa que João vai comprar, apenas com sua descrição.

(125) a. João vai comprar uma casa que o agrada.

b. João vai comprar uma casa que o agrade.

O autor, no entanto, considera que o indicativo poderia levar às duas leituras do NP, referencial ou não-referencial, e que as sentenças exemplificadas podem ser tomadas como sinônimas nesse sentido, de forma que o papel semântico do subjuntivo nesses contextos tenderia a desaparecer.

De forma análoga, comparando apenas presente do indicativo e do subjuntivo, Marques (1995), postula que o indicativo seria selecionado em orações relativas cujo elemento antecedente tem uma leitura específica, referindo-se a uma entidade concreta, enquanto o subjuntivo seria selecionado em orações relativas cujo elemento antecedente tem uma leitura não específica, a qual não se refere a entidades concretas. Retomando conceitos de Montague (1969), o autor descreve que o subjuntivo em orações relativas só pode ocorrer em contextos de verbos opacos (a exemplo de procurar e querer), aqueles que têm como complemento a intensão de um constituinte e que permitem uma leitura não específica.

Contextos de verbos transparentes, por sua vez (como encontrar e descobrir), tem como complemento a extensão de um constituinte, permitindo apenas uma leitura específica e selecionando sempre o indicativo, como em (126a). Por identificar uma entidade específica e, portanto, concreta e referencial, o subjuntivo não pode ocorrer nesses casos, como vemos em (126b). Verbos opacos, como em (127), possibilitam a leitura não específica, motivo pelo qual a seleção de subjuntivo é possível em (127b). O indicativo em (127a), por sua vez, seria ambíguo para uma leitura específica ou não específica.

(126) a. João encontrou um livro que trata da história do Brasil.

b. * João encontrou um livro que trate da história do Brasil.

(127) a. João procura um livro que trata da história do Brasil.

b. João procura um livro que trate da história do Brasil. 
Comrie e Holmback (1984) tem uma abordagem parecida. Retomando brevemente o que já foi explorado no Capítulo 1, os autores consideram que em uma oração relativa com indicativo (128a), o DP/NP antecedente pode ser ambíguo entre referencial ou nãoreferencial. O subjuntivo (128b), por sua vez, marcaria apenas a não-referencialidade, sendo, portanto, a maneira preferencial de fazê-lo.

(128) a. João vai casar com uma mulher que tem muito dinheiro.

b. João vai casar com uma mulher que tenha muito dinheiro.

Em abordagem mais geral, a análise de dados de outras línguas aponta também que o subjuntivo em orações relativas indicaria uma leitura atributiva/não-específica do DP antecedente, enquanto o indicativo nesse mesmo contexto permitiria tanto essa mesma leitura atributiva como uma leitura referencial/específica, na mesma linha do que é defendido pelos autores acima mencionados em se tratando de dados do português. De encontro a essas abordagens, (Quer, 1998, 2008) avalia que a ambiguidade de leituras atribuída ao indicativo é apenas aparente, e que o contraste entre indicativo e subjuntivo em orações relativas está relacionado a efeitos de escopo e ao modelo em que a proposição deve ser avaliada. Detalharemos em seguida a proposta do autor.

\section{Escopo largo e escopo estreito (Quer, 1998, 2008)}

Retomando o que descrevemos na seção 3.2.1, Quer $(1998,2008)$ defende que a seleção do modo subjuntivo por determinados predicados está diretamente ligada à mudança de modelo em que a proposição deve ser interpretada, do modelo epistêmico default (seja ele o modelo do falante, $\mathrm{ME}(\mathrm{s})$, ou o de outro referente, $\mathrm{ME}(\mathrm{x})$ ) para um modelo de alternativas buléticas, $\operatorname{MBul}(\mathrm{x})$. O papel do subjuntivo, então seria o de sinalizar a presença de um modelo de avaliação diferente do modelo default.

(129) a. Eles querem contratar uma secretária [que fala inglês] ME(s)/ ME(eles)

b. Eles querem contratar uma secretária [que fale inglês] MBul(eles)

O verbo intensional forte querer dá condições para a ocorrência do subjuntivo em (129b). Além disso, ele introduz um modelo bulético cuja âncora individual é o sujeito da oração principal. Assim, o subjuntivo em (129b) indica que a propriedade expressa pela oração relativa (falar inglês) deve ser avaliada em relação a MBul(eles), modelo introduzido pelo verbo querer. O indicativo em (129a), por sua vez, marca o fato de que essa propriedade deve ser avaliada em relação ao modelo epistêmico do falante ME(s) ou ao modelo epistêmico do sujeito referente da oração principal ME(eles), e não em relação ao modelo introduzido pelo verbo.

Segundo o autor, portanto, a ambiguidade de leituras produzida pelo indicativo em contexto de orações relativas que alternam com o subjuntivo é apenas aparente, haja 
vista que os modelos de avaliação não são os mesmos. A variação de modo e consequente mudança de modelo refletem-se em efeitos de escopo, conforme os exemplos abaixo. O uso do indicativo em (130) produz um efeito de escopo largo da condição descritiva na encaixada em relação ao predicado intensional da matriz, enquanto o subjuntivo em (131) ocasiona um efeito de escopo estreito.

(130) a. Maria precisa de um argumento que é convincente.

b. $\left[\exists x\right.$ : argumento ${ }^{\prime}(x)$ ser-convincente $\left.\left.(x) \wedge \operatorname{PRECISAR~(Maria,~} x\right)\right]$

(131) a. Maria precisa de um argumento que seja convincente

b. PRECISAR (Maria, $\left[\exists x: \operatorname{argumento}^{\prime}(x) \wedge \operatorname{ser}\right.$-convincente $\left.\left.{ }^{\prime}(x)\right]\right)$

Na leitura referencial/específica, o DP fora do escopo do verbo em (130) refere-se a um único objeto em um mundo em particular, importando a identificação do referente. Sob o escopo de querer em (131), o DP atributivo/não-específico não se refere rigidamente a um único objeto, mas a possíveis diferentes objetos distintos em um conjunto de mundos possíveis. Neste caso, importa essencialmente a conexão entre a descrição e o referente, ou seja, que o referente cumpra as condições previstas pela descrição na relativa.

\subsection{O futuro do subjuntivo em orações relativas}

Conforme vimos ao longo deste capítulo, Quer $(1998,2008)$ propõe que a escolha de modo marca a mudança de modelo em que uma proposição deve ser avaliada: no caso do indicativo, um modelo epistêmico (132a); para o subjuntivo, um modelo bulético (132b).

(132) a. Eles querem contratar uma secretária [que fala inglês] ME(s)/ ME(eles)

b. Eles querem contratar uma secretária [que fale inglês] MBul(eles)

Em caso de orações relativas, o modo tem, ainda, ligação com efeitos de escopo: o indicativo gera uma leitura de escopo largo/referencial/específica do DP que antecede a encaixada (133), enquanto o subjuntivo tem uma leitura de escopo estreito/nãoreferencial/atributiva desse DP (136).

(133) a. Maria precisa de um argumento que é convincente.

b. $\left[\exists x\right.$ : $\operatorname{argumento}{ }^{\prime}(x)$ ser-convincente $(x) \wedge \operatorname{PRECISAR}($ Maria, $\left.x)\right]$ 
(134) a. Maria precisa de um argumento que seja convincente

b. PRECISAR (Maria, $\left.\left[\exists x: \operatorname{argumento}^{\prime}(x) \wedge \operatorname{ser}^{-\operatorname{convincente}}{ }^{\prime}(x)\right]\right)$

Vimos também determinadas condições que devem ser observadas para que o subjuntivo possa ocorrer em orações relativas: ele é gramatical apenas em orações relativas restritivas, não apresenta restrição quanto ao tipo de $\mathrm{DP} / \mathrm{NP}$ antecedente, com exceção de demonstrativos, e é licenciado apenas em determinados contextos, chamados por Quer (1998, 2008) de ambientes intensionais (quando há predicados intensionais fortes, tempo futuro, operadores de negação e orações interrogativas, condicionais e imperativas). O trabalho de Quer $(1998,2008)$ apresenta sentenças comparativas entre presente do indicativo e do subjuntivo, não tratando de questões temporais, uma vez que se baseia em dados do espanhol e do catalão, línguas que não atestam um uso produtivo do futuro do subjuntivo. Dessa forma, é interessante verificar como a proposta do autor se adequaria à descrição e análise de dados do português, passando em revista os pontos acima elencados. Em primeiro lugar, tratando ainda de questões de modo, mesmo que consideremos que a alternância entre indicativo e subjuntivo na encaixada marca uma mudança de modelo (de um modelo epistêmico com o indicativo, para um modelo bulético com o subjuntivo), não obstante devemos levar em consideração que, de fato, falantes de português brasileiro aceitam que a versão com indicativo pode ter duas interpretações, sejam elas as definidas como referencial (135b) ou atributiva (135c), enquanto o subjuntivo, como o esperado, tem apenas essa última leitura (136b).

(135) a. Maria precisa de um argumento que é convincente.

b. $[\exists x$ : argumento ' $(x)$ ser-convincente $(x) \wedge \operatorname{PRECISAR~(Maria,~} x)]$

c. PRECISAR (Maria, $\left.\left[\exists x: \operatorname{argumento}^{\prime}(x) \wedge \operatorname{ser}^{-\operatorname{convincente}}(x)\right]\right)$

(136) a. Maria precisa de um argumento que seja convincente

b. PRECISAR (Maria, $\left.\left[\exists x: \operatorname{argumento}^{\prime}(x) \wedge \operatorname{ser}^{-\operatorname{convincente}}(x)\right]\right)$

Reconhecendo essa ambiguidade, teríamos que assumir que, nesse caso, a proposição com indicativo também poderia ser avaliada no modelo bulético, geralmente introduzido pelo subjuntivo, de forma que o modo não estaria marcando abertamente as mudanças de modelo.

(137) a. Eles querem contratar uma secretária [que fala inglês].ME(s)/ ME(eles)/ MBul(eles)

b. Eles querem contratar uma secretária [que fale inglês].MBul(eles)

Ainda assim, parece plausível assumir que há uma tendência a se interpretar o indicativo em um modelo epistêmico. Em (138a), por exemplo, a interpretação mais saliente 
para o DP que antecede a relativa é a referencial/específica, ou seja, em que se pode identificar o autor a que o falante se refere. Em (138b), como esperado, temos uma interpretação atributiva do DP, que se refere a qualquer autor que cumpra a condição de ser brasileiro.

(138) a. João quer ler um livro de um autor [que é brasileiro] ME(s)/ ME(João)

b. João quer ler um livro de um autor [que seja brasileiro] MBul(João)

Até esse ponto, assim como Quer (1998, 2008), comparamos sentenças com presente do indicativo e do subjuntivo em contexto de orações relativas, sem considerar a possibilidade de comparação também entre futuro do indicativo e do subjuntivo nesse contexto. Interessante notar, ainda, que os autores citados na seção 4.2.1, ao tratarem de dados do português, também não comparam sentenças com o futuro como (139).

(139) a. João vai demitir os funcionários que chegarem atrasados.

b. João vai demitir os funcionários que chegarão atrasados.

Neste caso, a alegada ambiguidade do indicativo parece não se confirmar. Em outras palavras, pela comparação entre as sentenças acima, a leitura atributiva em (139a), com futuro do subjuntivo, e a leitura referencial em (139b), com futuro do indicativo, aparentam ser as únicas interpretações possíveis para o antecedente. No entanto, sob determinados ajustes, uma oração relativa com futuro do indicativo também pode apresentar um NP antecedente atributivo, como acontece em (140). Nesse caso, a leitura mais saliente é a de que o NP não descreve um aluno específico no contexto, mas qualquer aluno que satisfaça a condição descrita na relativa.

(140) Pedro está procurando um aluno que se formará esse ano.

Estender a discussão acerca dos contrastes entre indicativo e subjuntivo em contexto de orações relativas está além do foco deste trabalho. Por ora, nos basta observar que os dados confirmar que a escolha de uso subjuntivo nesse contexto, seja com presente ou futuro, aponta, invariavelmente, para uma leitura atributiva do DP antecedente. Além disso, como já apontado, para além da alternância de indicativo e subjuntivo, é possível também haver alternância entre tempos de um mesmo modo, como o presente e o futuro do subjuntivo em (141), sem que a diferença entre as duas formas esteja evidente.

(141) a. João quer sair com mulheres que tenham muito dinheiro.

b. João quer sair com mulheres que tiverem muito dinheiro.

Convém neste ponto retomarmos as características que tornam possíveis o subjuntivo em orações relativas conforme descritas na seção 4.1, passando em revisão como elas se 
relacionam especificamente ao uso do futuro do subjuntivo nesses ambientes, uma vez que até então os exemplos apresentavam apenas sentenças com o presente e o passado do subjuntivo. Quanto à primeira condição, nada de especial há que ser falado: o futuro do subjuntivo também é gramatical em orações relativas restritivas e agramatical em orações relativas apositivas.

(142) a. João vai comprar o peixe que estiver mais fresco.

b. * João vai comprar o peixe, que estiver mais fresco.

Em segundo lugar, à exceção de DPs demonstrativos, também não há restrições quanto ao tipo de $\mathrm{DP} / \mathrm{NP}$ antecedente da oração relativa:

(143) a. * João vai comprar esse peixe que estiver fresco.

b. João vai comprar o peixe que estiver mais fresco.

c. João vai comprar um peixe que estiver fresco.

d. João vai comprar peixes que estiverem frescos.

e. João vai comprar qualquer peixe que estiver fresco.

f. João vai comprar algum peixe que estiver fresco.

g. João vai comprar todos os peixes que estiverem frescos.

Em terceiro lugar, vimos que, não havendo seleção lexical de modo como acontece em outros contextos, o subjuntivo na oração relativa é licenciado quando há determinados ambientes na matriz, como na presença de predicados intensionais fortes, tempo futuro, operadores de negação e predicados de leitura habitual. Aqui, os dados mostram que o futuro do subjuntivo tem restrições: ele é licenciado apenas por um tempo futuro na matriz (144a) ou por um predicado intensional que, de alguma forma, desloque a referência temporal para o futuro em relação ao momento de fala (144b). Por comparação, vemos que o presente do indicativo pode ser licenciado nesses e nos outros casos, com operadores de negação (144c) e predicados de leitura habitual (144d), quando não há esse deslocamento do momento de fala para um momento no futuro.

(144) a. João votará em candidatos que façam/fizerem bons discursos

b. João quer votar em candidatos que façam/fizerem bons discursos

c. João não vota em nenhum candidato que faça/*fizer bons discursos.

d. João sempre vota em candidatos que façam/*fizerem bons discursos

Os exemplos mostram que, apesar de o futuro do subjuntivo ser mais restrito do que o presente, ainda assim os dois podem competir entre si em casos em que há uma referência futura na matriz, como nas sentenças abaixo retomadas. 
(145) a. João votará em candidatos que façam bons discursos.

b. João votará em candidatos que fizerem bons discursos.

(146) a. João quer votar em candidatos que façam bons discursos.

b. João quer votar em candidatos que fizerem bons discursos.

A diferença entre os pares de sentença, intuitivamente, parece estar relacionada à situação descrita na encaixada: ainda que tenhamos referência futura com relação ao momento de fala tanto em (145) quanto em (146), as versões com presente do subjuntivo parecem fazer referência a uma característica própria dos candidatos - ou seja, à qualidade de bons oradores -, enquanto as versões com futuro do subjuntivo, por sua vez, parecem fazer referência a um intervalo de tempo mais restrito - por exemplo, ao período de campanha que antecede a votação - ou seja, a campanha eleitoral. A descrição mais detalhada das restrições que envolvem o futuro do subjuntivo e sua comparação com o presente do subjuntivo serão tema dos capítulos subsequentes, em que abordaremos especificamente questões de tempo e aspecto até então ignoradas.

\subsection{Conclusão}

Iniciamos este capítulo descrevendo brevemente os ambientes de distribuição do modo subjuntivo (orações subjetivas, completivas, adverbiais e relativas) e chamando a atenção para o fato de que uma análise unificada do modo subjuntivo em oposição ao indicativo em todos os seus contextos de uso é uma tarefa complexa. Vimos neste capítulo um panorama de trabalhos que abordam essa questão a partir de Portner (2018), com ênfase em orações completivas, descrevendo os principais tipos de predicados que selecionam um modo ou outro. Voltamos nossa atenção em seguida à proposta de Quer (1998, 2008), que se estende também a orações relativas e segundo a qual a) o uso dos modos indicativo ou subjuntivo determina o modelo (epistêmico ou bulético, respectivamente) em que a proposição deve ser avaliada e b) o subjuntivo pode ser dividido em dois tipos, o intensional, lexicalmente selecionado, e o de polaridade, licenciado por operadores. Este último é o que parece melhor se adequar ao quadro geral das orações relativas com subjuntivo, as quais requerem determinados ambientes na matriz, como a presença de predicados intensionais fortes, tempo futuro ou um operador de negação. Nossa análise propõe que o futuro do subjuntivo é ainda um pouco mais restrito nesse ambiente, uma vez que seu uso requer sempre uma referência futura na matriz. Vimos também que nos contextos de subjuntivo em orações relativas não há restrição quanto ao tipo de DP/NP antecedente à encaixada, mas sua interpretação é sempre não-referencial/atributiva, enquanto a alternância com o 
indicativo levaria preferencialmente a uma interpretação referencial/específica desse antecedente. Esses pontos foram discutidos sem nos atermos ainda com profundidade a questões temporais e aspectuais, as quais serão abordadas nos capítulos subsequentes. 


\section{Capítulo 3}

\section{Tempo}

\subsection{Introdução}

Como já exposto, as pesquisas sobre o modo subjuntivo detém-se, normalmente, em sua oposição com o modo indicativo, sem ênfase quanto aos diversos tempos em que o subjuntivo pode se apresentar e ao significado a eles associado ${ }^{1}$. Isso talvez se deva ao fato de os tempos do subjuntivo, em geral, fazerem oposição apenas entre as formas presente e passada. Neste ponto, consideramos que o português pode ser especialmente interessante, uma vez que conta em seu sistema verbal também com uma forma futura do subjuntivo, inexistente ou em desuso em outras línguas românicas ${ }^{2}$.

Conforme descreveremos com mais detalhes ao longo deste capítulo, o futuro do subjuntivo é encontrado em orações subordinadas adverbiais e relativas, ambientes em que também se verifica o uso do presente e do passado do subjuntivo. Algumas restrições podem ser observadas, no entanto. Em orações adverbiais (147a a 147d), presente e futuro do subjuntivo são mutuamente excludentes, de forma que a oração relativa (147e) é o único contexto em que as duas formas podem de fato se alternar. Além disso, o presente é selecionado em orações completivas (147f), caso em que o futuro é sempre agramatical.

(147) a. Se João estiver/*esteja em casa, ele vai atender o telefone.

b. João vai dormir quando chegar/*chegue em casa.

c. Caso João esteja/*estiver em casa, ele vai atender o telefone.

d. Maria vai esperar até que João termine/*terminar os exercícios.

e. João quer casar com uma mulher que tenha/tiver muito dinheiro.

f. João espera que não chova/*hover

\footnotetext{
${ }^{1}$ Para um estudo sobre os tempos do subjuntivo em português europeu, ver Marques (2010), já brevemente descrito no Capítulo 1.

${ }^{2}$ Comrie e Holmback (1974); Marques (2010)
} 
Apesar de poderem se alternar em ambientes de oração relativa como em (147e), vimos que também nesse contexto o futuro do subjuntivo tem uma distribuição mais limitada do que o presente, uma vez que ele só é lícito quando há na matriz um tempo futuro ou um predicado intensional que, de alguma forma, desloque a referência temporal para o futuro em relação ao momento de fala. Vimos também propostas que buscam explicar os contrastes entre presente e futuro do subjuntivo, em especial Marques (2010) e Comrie e Holmback (1984), autores que consideram que a diferença entre essas duas formas de subjuntivo não é de natureza temporal. Distanciando-nos desses autores e partindo de Ferreira (2018), a proposta a ser detalhada neste capítulo é a de que o futuro do subjuntivo deve ser considerado um tempo referencial não-passado, ancorado ao momento de fala. Para tanto, organizamos o capítulo da seguinte forma: na seção 3.2 voltaremos nossa atenção aos tempos simples (passado, presente e futuro) do subjuntivo, descrevendo como o tempo está relacionado a padrões e restrições distribucionais desse modo. Na seção 3.3 apresentaremos o referencial teórico que servirá de base para a nossa análise, detalhando a relação entre momento de fala e momento de tópico de acordo com Klein (1994, 2009) e a analogia entre pronomes e tempos verbais proposta por Partee (1973). Na seção 3.4 apresentamos a proposta de Ferreira (2018), a qual descreve o futuro do subjuntivo como um tempo referencial futuro, procedendo, a partir dela, à análise de dados, a qual deve sustentar a proposta de generalização para o futuro do subjuntivo em orações relativas como um tempo referencial não-passado.

\subsection{A distribuição dos tempos do modo subjuntivo}

Nesta seção veremos como o modo subjuntivo e os seus tempos verbais morfologicamente marcados interagem no que diz respeito à relação entre a informação temporal que veiculam e à distribuição sintática descrita nas seções anteriores.

São seis as formas - ou tempos - do modo subjuntivo em português, três simples e três compostas, designadas tradicionalmente como pretérito imperfeito (148a), presente (148b), futuro (148c), pretérito mais-que-perfeito (148d), pretérito perfeito (148e) e futuro perfeito $(148 \mathrm{f})^{3}$ :

(148) a. Se você terminasse os exercícios, poderia sair.

b. Termine os exercícios para que você possa sair.

c. Quando você terminar os exercícios, poderá sair.

d. Se você tivesse terminado os exercícios, poderia sair.

e. Espero que você tenha terminado os exercícios para poder sair.

\footnotetext{
${ }^{3}$ Nomenclatura conforme sugerida em Marques (2010).
} 
f. Quando você tiver terminado os exercícios, poderá sair.

Conforme descrito no capítulo 2, o subjuntivo é um modo típico de orações subordinadas, em especial as subjetivas, completivas, adverbiais e relativas. Considerando-se as suas três formas simples (pretérito imperfeito, presente e futuro), no entanto, vemos que sua distribuição não é uniforme, ou seja, que não encontramos todas as três formas em todos os contextos de uso.

Em orações subordinadas completivas, por exemplo, o futuro do subjuntivo é sempre agramatical. Como discutido na seção anterior para estes casos, o tempo do verbo da oração encaixada pode (149a e 149b) ou não (150a) ser dependente da oração matriz. Porém, ainda que a oração principal tenha orientação futura, o futuro do subjuntivo não é selecionado na subordinada (150b), quando então podemos ter apenas o presente.

(149) a. O João queria que a Maria chegasse mais cedo.

b. O João quer que a Maria chegue mais cedo.

(150) a. O João pediu que a Maria chegue mais cedo.

b. O João pedirá que a Maria chegue/*chegar mais cedo.

Em orações subordinadas adverbiais, por sua vez, as instâncias de uso do subjuntivo são mais variadas. Retomando exemplos anteriores, podemos verificar que a forma passada do subjuntivo está disponível para todos os contextos em que esse modo é selecionado ou licenciado:

(151) a. Mesmo que estivesse doente, João foi trabalhar.

b. João abriu a porta do carro para que sua namorada entrasse.

c. João reagirá/reagiu como se tivesse tomado um susto.

d. João faria os exercícios conforme o professor pedisse.

e. Quanto mais João corresse, mais cansado ficaria.

f. Se o João estivesse em casa, ele atenderia o telefone.

g. João iria dormir assim que chegasse em casa.

O mesmo não ocorre, porém, com o presente e o futuro. Considerados um como competidor do outro no sistema verbal do português brasileiro, ${ }^{4}$, eles se diferenciam bastante no que concerne a sua distribuição. Salvo certas liberdades estilísticas, os contextos de uso de presente e futuro do subjuntivo em orações adverbiais são bem definidos e excludentes entre si. Encontramos o futuro em orações adverbiais condicionais (152a) introduzidas

\footnotetext{
${ }^{4}$ Comrie e Homlback (1984), Marques (2010)
} 
por se, em temporais (152b) introduzidas por quando, enquanto, assim que, sempre que e depois que, e em conformativas (152c) e proporcionais (152d) em geral.

(152) a. Se João estiver $/{ }^{*}$ esteja em casa, ele vai atender o telefone.

b. João vai dormir assim que chegar $/{ }^{*}$ chegue em casa.

c. João vai fazer os exercícios conforme o professor pedir/*peça.

d. Quanto mais João comer $/{ }^{*}$ coma, mais vai engordar.

O presente é agramatical nesses contextos. Ele é, por sua vez, encontrado em orações subjetivas (153a), em orações adverbiais condicionais (153b) introduzidas por caso, em temporais (153c) introduzidas por antes que e até que, e em concessivas (153d) e finais em geral (153e). Da mesma forma, o futuro é agramatical nesses ambientes.

(153) a. É possível que o João esteja/*estiver em casa.

b. Caso João esteja/*estiver em casa, ele vai atender o telefone.

c. Maria vai esperar até que João termine/*terminar os exercícios.

d. Mesmo que esteja/*estiver doente, João vai trabalhar.

e. João vai abrir a porta para que Maria entre/*entrar.

No que se refere às orações subordinadas relativas, no entanto, a distinção entre a distribuição do presente ou do futuro do subjuntivo não parece tão trivial, uma vez que ela não é determinada por seleção lexical. De fato, como já apontado anteriormente, presente (154a) e futuro (154b) podem se alternar em contextos de matrizes idênticas:

(154) a. João quer casar com uma mulher que tenha muito dinheiro.

b. João quer casar com uma mulher que tiver muito dinheiro.

Vimos no capítulo 1 dois trabalhos que tratam das distinções entre presente e futuro do subjuntivo. Comrie e Holmback (1984), cujo objetivo é o de propor uma análise precisa e unificada para o futuro do subjuntivo em português em seus variados contextos de distribuição, buscam também caracterizar a natureza da oposição entre futuro e presente do subjuntivo. Tendo isso em vista, a proposta dos autores é de que presente e futuro do subjuntivo competem entre si, ambos indicando referência temporal não-passada. Segundo os autores, o futuro do subjuntivo não seria 'mais futuro' do que o presente, apenas mais definido do que ele. Em orações adverbiais, a maior definitude se daria em relação à situação descrita na oração subordinada. Em orações relativas, a definitude estaria relacionada ao elemento antecedente, aquele que a relativa descreve. Marques (2010) também considera que presente e futuro do subjuntivo não tem distinções temporais. A diferença entre eles estaria relacionada a uma maior restrição do futuro do subjuntivo em relação ao 
presente no que diz respeito a seus contextos de distribuição. Ferreira (2018), por sua vez, sugere que o futuro do subjuntivo deve ser considerado um tempo referencial, apontando para um intervalo de tempo futuro, proposta em que basearemos a nossa análise. Antes, no entanto, convém descrever a base teórica que tomaremos em conta neste capítulo.

\subsection{Referencial teórico}

Tomamos por base teórica, por um lado, a teoria de tempo de Klein (1994, 2009), segundo a qual o tempo verbal é codificado nas línguas naturais a partir de três conceitos: o tempo de fala (TU), momento em que o enunciado é expresso; o tempo da situação (Tsit), momento em que a situação ocorre; e o tempo de tópico (TT), momento sobre o qual algo é falado. Neste quadro, o tempo de uma sentença é determinado pela relação de tempo de fala (TU) e tempo de tópico $(\mathrm{TT})^{5}$, conforme será exposto na próxima subseção. Em seguida, apresentamos também uma breve descrição da proposta de Partee (1973) acerca das propriedades compartilhadas por tempos e pronomes em relação a seus usos dêiticos e anafóricos.

\subsubsection{Klein $(1994,2009)$ : tempo de fala (TU) e tempo de tópico (TT)}

Consideramos aqui o tempo não em sua acepção cronológica, mas como uma categorial gramatical. Nesse sentido, ele é visto tradicionalmente como uma categoria dêitica do verbo, indicando uma relação temporal entre uma situação ${ }^{6}$ descrita na sentença e sua localização em relação ao momento de fala. A essa âncora dêitica Klein se refere como TU (ou o tempo de fala). A partir dela, três relações temporais são tipicamente assumidas, determinando os três tempos verbais básicos: passado (155a), quando o tempo da situação antecede TU; presente (155b), quando o tempo da situação é concomitante a TU; e futuro (155c), quando o tempo da situação é posterior a TU.
(155) a. Maria dormiu.
b. Maria dorme.
c. Maria dormirá.

Cada uma das sentenças acima, portanto, posiciona a situação de dormir antes, durante ou após o momento de fala, marcando os tempos passado, presente e futuro. São os tempos absolutos, de acordo com Comrie (1985), localizados a partir de uma âncora dêitica (TU, o momento de fala). Klein $(1994,2009)$ aponta como exemplos triviais deixam

\footnotetext{
${ }^{5}$ No original, time of utterance (TU), topic time (TT) e time of the situation (Tsit).

${ }^{6}$ Usamos o termo situação para abarcar todos os tipos de estados, eventos e processos. Esses conceitos serão retomados no capítulo 4 .
} 
clara a complexidade que a simples definição de tempos verbais a partir da sua relação entre o tempo de uma situação e o tempo de fala parece não capturar. Em uma sentença como (156), por exemplo, nada impede que a situação de Maria estar triste ainda esteja acontecendo em TU, de forma que seria insuficiente classificar o tempo como passado, tendo em conta que o passado localizaria a situação em um momento anterior a TU.

Maria estava triste.

Já em (157), supondo que o gato de Maria esteja de fato morto, ele ainda estaria morto em TU. Assim, se o intervalo de tempo da situação é o momento em que a situação se dá, a classificação de passado acima proposta também não parece apropriada, uma vez que, nesse caso, ele teria que se estender ao presente e ao futuro.

O gato da Maria estava morto.

A saída encontrada por Klein $(1994,2009)$ é, para além de determinar o tempo de fala (TU), momento em que o enunciado é expresso, e o tempo da situação (Tsit), momento em que a situação acontece, assumir também a existência de um tempo de tópico (TT), o momento sobre o qual algo é falado ou perguntado. Quando alguém diz (157), se diz algo sobre um intervalo de tempo no passado, ou seja, sobre o tempo de tópico (TT). TT pode ser análogo ou não ao tempo em que a situação se dá. Em (157), por exemplo, ele não é, uma vez que a situação (o gato estar morto) se projeta ao presente e ao futuro. Nesse caso, TT é apenas um subintervalo de tempo de Tsit.

Dessa forma, Klein $(1994,2009)$ defende que a categoria de tempo verbal não expressa uma relação entre o momento em que uma situação acontece e o momento de fala, e sim, entre TU, o momento de fala, e TT, o intervalo de tempo sobre o qual o falante quer dizer alguma coisa ${ }^{7}$. A descrição dos tempos verbais básicos pode, então, ser atualizada. Temos passado quando TT antecede TU; presente quando TT é concomitante a TU; e futuro quando TT é posterior a TU.

Tomemos outro exemplo de Klein $(1994,2009)$ para melhor ilustrar o conceito de TT e torná-lo mais claro. Consideremos que a resposta para (158a) pode ser (158b):

(158) a. O que você viu quando entrou na sala?

b. Tinha um livro em cima da mesa.

A pergunta em (158a) delimita o tempo do tópico (TT). A pessoa deve responder sobre aquele momento especificamente, nenhum outro, ou seja, em (158a), o momento em que a pessoa entrou na sala. Nesse TT específico e relevante delimitado pela pergunta, havia um livro sobre a mesa. Considerando a propriedade temporária característica dessa

\footnotetext{
${ }^{7}$ Outra relação possível, entre TT e Tsit, será abordada no capítulo 4, quando trataremos de questões aspectuais.
} 
situação, podemos supor um outro TT, como TT', em que o livro ainda não estava sobre a mesa, assim como um TT" em que ele não está mais lá. Mesmo assim, nada se pode dizer da relação entre a situação de o livro estar na mesa e TU, o momento de fala. Não se sabe se o livro ainda está lá. O que é relevante para determinar o tempo passado na sentença é a relação de precedência entre TT, o tempo do tópico (o momento em que a pessoa entrou na sala, ou seja, o momento sobre o qual se fala algo) e TU. Consideremos que a resposta continua como em:

Era um livro em russo.

O TT ainda é o mesmo. No entanto, dadas as propriedades permanentes da situação descrita, já não se supõe a existência de um dado TT' em que o livro ainda não era em russo, tampouco um TT" em que o livro deixará de ser. De toda forma, temos o tempo passado na sentença, uma vez que, nesse sentido, nada mudou em relação a (158): TT precede TU, ou seja, o tempo sobre o qual algo é falado precede o tempo de fala. Em suma, para a localização temporal não importa, de fato, se a situação (evento, estado ou processo) é anterior, concomitante ou posterior a TU. O que conta é a relação entre TU e TT, o intervalo de tempo sobre o qual se diz algo relacionado à situação descrita na sentença. Essas observações serão retomadas na seção 3, quando trataremos da análise temporal do futuro do subjuntivo. Antes, voltemos nossa atenção à proposta de Partee (1973).

\subsubsection{Partee (1973): As analogias entre pronomes e tempos ver- bais}

Em trabalho precursor, Partee (1973) propõe que os tempos têm determinados usos análogos a pronomes, em especial no que se refere ao contraste entre seus usos dêiticos e anafóricos. O paralelo entre o uso dêitico dos pronomes e dos tempos pode ser ilustrado por (160), exemplo adaptado da autora. Em (160a), o falante faz referência a um indivíduo específico cuja identidade é determinada pelo contexto. Em (160b), o falante faz referência a um intervalo de tempo (definido no passado em que o forno não foi desligado) cuja identificação específica, assim como em (160b), é dada pelo contexto.

(160) a. Ele não deveria estar aqui.

b. Eu não desliguei o forno.

Já em uma sentença como (161a), o pronome é usado anaforicamente, referindo-se a um objeto anteriormente mencionado. O paralelo entre o uso anafórico dos tempos e dos pronomes pode ser visto em (161b), em que o tempo é especificado em uma sentença e a sentença seguinte se refere a esse mesmo tempo. 
(161) a. Maria pegou o carro emprestado ontem e João vai pegá-lo hoje.

b. Maria deu uma festa ontem e o João ficou bêbado.

Os exemplos aqui citados envolvem sempre o tempo passado, denotando um intervalo de tempo anterior à enunciação, cuja especificação é determinada anaforicamente por outros meios, como o contexto de fala. Estenderemos essa análise também ao tempo futuro do subjuntivo, argumentando que, assim como o passado, que denota um intervalo de tempo anterior ao tempo de fala, ele é também um tempo referencial, mas denotando um intervalo de tempo concomitante ou posterior ao momento da enunciação. Essa proposta tem como base o trabalho de Ferreira (2018), o qual será detalhado a seguir.

\subsection{O futuro do subjuntivo como um tempo referencial}

De acordo com Ferreira (2018), no sistema verbal dos tempos do indicativo em português padrão, passado e presente são tempos referenciais que denotam intervalos de tempo ancorados ao tempo de fala. O futuro, por sua vez, é usualmente considerado um operador, cujo papel temporal é indicar posterioridade em relação a um intervalo. Em inglês, por exemplo, considera-se a existência de um operador woll ${ }^{8}$, tendo will como forma presente e would como forma pretérita. Em português, esse operador futuro também pode unir-se tanto ao presente, compondo o futuro do presente, quanto ao passado, compondo o futuro do pretérito. Assim, o futuro se ancora em um tempo de referência que pode ser presente ou pretérito, resultando nas formas de futuro do presente (162a) e futuro do pretérito do indicativo (162b).

(162) a. Maria fará um bolo.

b. Maria faria um bolo.

A parte isso, Ferreira (2018) propõe que o sistema verbal do português conta também com um tempo referencial futuro, correspondendo ao futuro do subjuntivo. Esse tempo futuro denotaria um intervalo de tempo posterior ao tempo de fala e anterior ao tempo da matriz, como em $(163)^{9}$.

(163) João se reunirá com o candidato que for indicado pelo partido.

A partir da proposta de Ferreira (2018), passaremos a considerar o futuro do subjuntivo não como um tempo referencial futuro, mas como um tempo referencial não-passado, uma vez que os dados mostram que o intervalo de tempo que ele denota pode ser não apenas posterior ao momento de fala como no exemplo acima, mas também concomitante a ele, como em (164).

\footnotetext{
${ }^{8}$ Abusch (1997).

${ }^{9}$ Exemplo retirado de Ferreira (2018).
} 
(164) João demitirá os funcionários que estiverem dormindo (agora).

Em resumo, o tempo futuro do subjuntivo (representado por $T_{2}$ nos diagramas abaixo) pode ser concomitante ao momento de fala, (TU, de acordo com a nomenclatura proposta por Klein), como em (165), ou posterior a ele (de toda forma, nunca anterior), como em (166) e (167). Além disso, veremos também que esse intervalo de tempo denotado pelo futuro do subjuntivo estabelece relação não apenas com o momento de fala, mas também com o tempo da matriz $\left(T_{1}\right)$, podendo ser concomitante, como em (166) ou anterior a ele (nunca posterior), com em (165) e (167). Todas essas noções, melhor ilustradas abaixo, serão detalhadas nas seções a seguir.

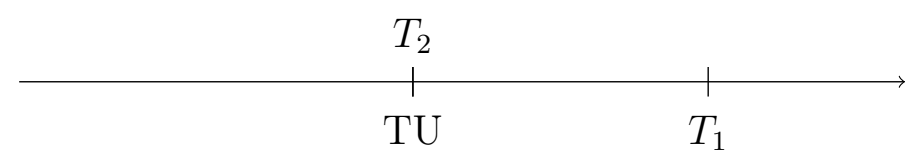

(166)

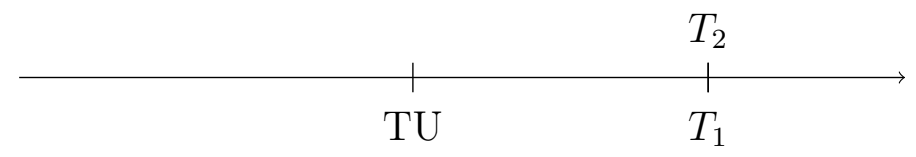

(167)

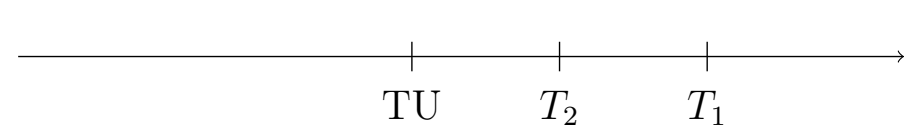

\subsubsection{A relação entre o futuro do subjuntivo e o momento de fala}

Como dissemos há pouco, o intervalo de tempo que o futuro do subjuntivo referencia pode estabelecer dois tipos de relação com o momento de fala, seja ela de concomitância ou de posteridade, nunca de anterioridade.

Podemos tomar como exemplo as sentenças em (168), as quais, em comparação, evidenciam que a situação descrita pelo futuro do subjuntivo nunca é anterior ao momento de fala. Para que isso seja ao menos possível, é necessário combiná-lo a uma forma perfeita, como em (168b). Assim, em (168a), a não entrega dos relatórios acontece necessariamente no futuro em relação ao momento de fala, enquanto em (168b) temos uma leitura 
disponível, ainda que não a única, de que ela acontece no passado em relação a esse momento.

(168) a. João demitirá os funcionários que não entregarem os relatórios.

b. João demitirá os funcionários que não tiverem entregado os relatórios.

O mesmo se percebe em (169). Em (169a) o teste será realizado no futuro em relação ao momento de enunciação, enquanto que em (169b) o teste pode ter acontecido no passado em relação a esse momento.

(169) a. João entrevistará os candidatos que acertarem todas as questões do teste.

b. João entrevistará os candidatos que tiverem acertado todas as questões do teste.

Estabelecido o tipo de relação que o futuro do subjuntivo não pode fazer com o momento de fala, voltemos nossa atenção às duas relações que são possíveis. Em (170a), (170b) e (170c), vemos que a relação entre o futuro do subjuntivo e TU é de concomitância.

(170) a. João contratará o candidato que for mais qualificado.

b. João demitirá todos os funcionários que estiverem dormindo (agora).

c. João entrevistará os candidatos que souberem mais de dois idiomas.

A outra relação possível entre o intervalo de tempo denotado pelo futuro do subjuntivo e TU é de posteridade. É o caso das sentenças abaixo retomadas, em que a entrega dos relatórios em (171a) e o teste em (171b) devem acontecer depois do tempo de fala:

(171) a. João demitirá os funcionários que não entregarem os relatórios.

b. João entrevistará os candidatos que acertarem todas as questões do teste.

Neste ponto, podemos fazer um breve retorno a Marques (2010). Considerando-se o tempo de enunciação como ponto de perspectiva temporal, o autor sugere que o futuro do subjuntivo em orações relativas pode ter localização de sobreposição se o predicado for estativo (173) e de posteridade se o predicado for não-estativo $(172)^{10}$.

(172) Entrevista as pessoas que encontrarem pelo caminho.

\footnotetext{
${ }^{10}$ Exemplos retirados de Marques (2010)
} 
(173) Eles querem fotografar os navios que estiverem afundados no porto.

Os nossos exemplos imediatamente anteriores (171a e 171b) mostram, de fato, predicados não-estativos com localização temporal de posteridade em relação ao momento de fala. Conforme vemos em (174), no entanto, mesmo predicados estativos podem indicar posteridade (e não apenas concomitância) em relação a TU.

(174) a. João vai comprar o peixe que estiver mais fresco (amanhã).

b. João vai votar no candidato que tiver mais tempo de televisão. (durante a campanha)

Em (174a), por exemplo, importa que o peixe esteja fresco no momento da compra, localizada no futuro em relação ao momento de fala. Já em (174b), o candidato escolhido será aquele que tiver mais tempo de propaganda partidária durante, por exemplo, o período de campanha política que antecede a votação, mas que é posterior a TU.

Neste ponto, começamos a ver também a relação existente entre o futuro do subjuntivo e o tempo da matriz. Isso será retomado na próxima subseção. Em outro momento, no capítulo seguinte, retornaremos também às distinções aspectuais entre predicados estativos e não-estativos. Por ora, das sentenças acima exemplificadas temos evidências para considerar o futuro do subjuntivo como um tempo referencial não-passado: ele está sempre ancorado ao momento de fala, apontando para um intervalo de tempo concomitante ou posterior a ele, nunca anterior.

\subsubsection{A relação entre o futuro do subjuntivo e o tempo da matriz}

Por ser um tempo subordinado, o futuro do subjuntivo não estabelece relação apenas com o momento de fala, mas também com o tempo da oração principal. Nesse caso, a relação pode ser de concomitância ou de anterioridade, nunca de posteridade, conforme veremos em detalhe.

Aqui convém retomarmos brevemente o conceito de tempo de tópico (TT) que detalhamos no início deste capítulo. Klein $(1994,2009)$ define o tempo de tópico como o momento sobre o qual algo é falado. Assim, podemos considerar que (175a) seja a resposta de uma pessoa questionada sobre o que viu no momento em que entrou na sala. O livro estar em cima da mesa é uma situação que se dá no momento relevante, o tempo de tópico, que corresponde, aqui, a um intervalo de tempo no passado, referente ao momento de entrada na sala. Nada se pode dizer, no entanto, sobre o livro estar ou não no mesmo lugar no momento de fala (TU). Em (175b), temos ainda o mesmo TT. Nesse caso, no entanto, tendo em vista as propriedades lexicais do predicado, é plausível dizer que o livro também era em russo antes de TT e continua em russo em TU e para além disso. O que temos, 
então, é TT (o momento de entrada na sala) como um subintervalo de tempo (passado) de uma situação permanente (o livro ser em russo).

(175) a. Tinha um livro em cima da mesa.

b. Era um livro em russo.

Tendo em mente esses conceitos, o que observaremos do futuro do subjuntivo é que ele se relaciona, invariavelmente, a um tempo de tópico (TT) saliente no contexto linguístico ou extralinguístico.

Vejamos primeiramente os contextos em que a relação é de concomitância entre o tempo da oração matriz e o futuro do subjuntivo na subordinada. Como já mencionado no capítulo 2, para que o futuro do subjuntivo seja licenciado em orações relativas deve haver, obrigatoriamente, um futuro na matriz, como por exemplo por meio do futuro do presente do indicativo (176).

João comprará o peixe que estiver mais fresco.

O licenciamento do futuro do subjuntivo na oração relativa também pode se dar por meio de um predicado intensional que desloque a referência para o futuro. Tomemos como exemplo as sentenças abaixo. Mesmo combinado a uma forma infinitiva, querer em (177a) altera o tempo de avaliação da sentença para o futuro, de forma que a compra do peixe deve ser posterior ao momento de fala. Esse futuro embutido em querer licencia o futuro do subjuntivo em (177b).

a. João quer comprar um peixe fresco.

b. João quer comprar o peixe que estiver mais fresco.

Em (176) e (177b), por exemplo, o tempo futuro do subjuntivo é concomitante ao tempo presente da oração principal (lembrando que o tempo futuro do presente do indicativo é composto por um tempo presente e um operador futuro), gerando uma interpretação de simultaneidade entre as duas situações descritas: João escolherá o peixe que estiver mais fresco no momento da compra (no TT relevante para essa sentença), ambos os eventos (a compra e o peixe estar fresco) localizados no futuro em relação a TU, o momento de fala.

Temos outro exemplo em (178): o intervalo de tempo na subordinada está ligado ao tempo da oração matriz, de forma que João escolherá votar no candidato que estiver em primeiro lugar nas pesquisas no momento da eleição (o TT em questão).

(178) João vai votar no candidato que estiver em primeiro lugar nas pesquisas. (no momento da votação) 
Assim, então, vemos que em (176) e (177b), o peixe deve estar fresco em TT (o momento da compra), da mesma forma que em (178), o candidato deve estar em primeiro lugar em TT (o momento da eleição). Esses são exemplos de sentenças de casos em que o futuro do subjuntivo é concomitante ao tempo da matriz e ambos são posteriores ao momento de fala. Aqui, portanto, vemos que o futuro do subjuntivo estabelece relação de posterioridade em relação ao momento de enunciação e de simultaneidade em relação ao tempo subordinante da oração principal. Em outras palavras, o futuro do subjuntivo denota nesses contextos um intervalo de tempo futuro simultâneo a outro intervalo de tempo também futuro.

Como já citado, no entanto, a relação com o tempo da matriz pode ser também de anterioridade. Nestes casos, o futuro do subjuntivo não está ligado ao tempo subordinante, mas sim busca sua referência no contexto, seja ele o contexto linguístico, em uma sentença anterior, seja ele o contexto extralinguístico, situações em que o tempo de tópico fica mais evidente.

É o que acontece em (179), em que futuro do subjuntivo aponta para um TT saliente extralinguisticamente. Podemos considerar um contexto, por exemplo, em que haverá uma reunião importante no dia seguinte e que João demitirá os funcionários que não chegarem no horário.

(179) João demitirá os funcionários que se atrasarem. (para a reunião de amanhã)

O mesmo contexto pode ser aplicado a (180a). Em (180b), podemos imaginar um processo de seleção que acontecerá em breve, para o qual um teste é pré-requisito.

(180) a. João demitirá os funcionários que dormirem. (na reunião de amanhã)

b. João entrevistará os candidatos que acertarem todas as questões do teste.

Em (179) e (180a), portanto, o TT relevante é o momento da reunião. Em (180b), por sua vez, o TT é o momento do teste durante o processo seletivo. Em ambos os casos, os eventos da subordinada são posteriores ao tempo de fala, mas anteriores ao tempo da matriz.

Vejamos um exemplo em que a relação do futuro do subjuntivo com o tempo de tópico parece particularmente esclarecedora para a interpretação do futuro do subjuntivo. Este exemplo é análogo ao do início desta seção, abaixo retomado, em que o TT relevante (o momento da entrada na sala) foi descrito como um subintervalo de tempo (passado) de uma situação permanente (o livro ser em russo).

(181) a. Tinha um livro em cima da mesa.

b. Era um livro em russo. 
Em (182), considerando que o tópico relevante para a sentença são as eleições que se aproximam, não é lógico supor que os candidatos serão paulistas apenas nesse momento, que não o eram no passado ou que após a eleição eles o deixarão de ser. O que temos é um momento sobre o qual algo é dito, ou seja, um TT (a eleição) que sucede o momento de fala (TU). Assim, TT, o momento sobre o qual se diz algo, é um subintervalo de tempo (futuro) de uma situação permanente (ser paulista).

(182) João votará em candidatos que forem paulistas.

Em síntese, como ilustram os dados apresentados, o futuro do subjuntivo estabelece relação de concomitância ou posterioridade com o tempo de fala e de concomitância ou anterioridade com o tempo da matriz, relacionando-se sempre a um tempo de tópico relevante para a sentença.

Outra questão que parece emergir dos dados é que, em casos em que o tempo de tópico coincide com o evento da matriz (como em (183), em que o TT é o momento da compra, e em (184), em que o TT é o momento da eleição), as diferenças entre presente e futuro do subjuntivo são menos contrastantes.

(183) a. João comprará peixes que estejam frescos.

b. João comprará peixes que estiverem frescos.

(184) a. João votará em candidatos que sejam paulistas.

b. João votará em candidatos que forem paulistas.

Quando temos um tempo de tópico saliente no contexto, no entanto, o contraste é mais evidente. Em (185), considerando que o TT relevante é o período de campanha, a versão com o presente do subjuntivo pode ser até menos aceitável do que a sentença com o futuro.

(185) a. ?João votará em candidatos que visitem São Paulo. (durante a campanha)

b. João votará em candidatos que visitarem São Paulo. (durante a campanha)

Por considerarmos a relevância da comparação entre presente e futuro do subjuntivo no contexto de orações relativas, retornaremos a essa discussão sobre o contraste entre as duas formas no próximo capítulo, abordando a questão a partir de noções aspectuais do predicado relacionando-as também ao tempo de tópico. Por ora, voltemos às relações estritamente temporais que envolvem o nosso objeto de estudo. 


\subsubsection{A restrição do futuro do subjuntivo}

A partir dos exemplos propostos fica evidente ainda uma outra propriedade do futuro do subjuntivo, a qual passamos a descrever nesta última seção. Além de o intervalo de tempo que o futuro do subjuntivo referencia a) ser posterior ou concomitante ao momento de fala (nunca anterior) e b) ser anterior ou concomitante ao tempo da oração principal, ele também c) nunca pode suceder o tempo da matriz. Em outras palavras, o intervalo de tempo denotado pelo futuro do subjuntivo está restrito entre o momento de fala e o tempo subordinante. Tomemos (186) como exemplo: aqui, a única interpretação disponível é a de que as visitas a São Paulo, o evento da subordinada, têm que acontecer necessariamente antes das eleições, ou seja, antes do evento da matriz.

(186) João vai votar em candidatos que visitarem São Paulo. (antes das eleições).

Em comparação, podemos ver que ao futuro do indicativo essa restrição não se aplica: em (187) não há nenhum ordenamento obrigatório dessas situações, ou seja, não se sabe se as visitas acontecerão antes ou depois das eleições.

(187) João vai votar em candidatos que visitarão São Paulo (antes ou depois das eleições).

Vejamos um segundo exemplo. Se considerarmos que promessas de campanha são normalmente feitas para serem cumpridas após as eleições, o exemplo em (188a) é pragamaticamente anômalo, uma vez que a única interpretação disponível para o futuro do subjuntivo é de que elas seriam cumpridas antes do resultado do pleito, por exemplo, durante a campanha, o que faria pouco sentido. A interpretação saliente para (188b) é a que esperamos, ou seja, aquela em que as promessas são cumpridas após a votação.

(188) a. \#João vai votar em candidatos que cumprirem suas promessas. (durante a campanha, antes das eleições)

b. João vai votar em candidatos que vão cumprir suas promessas. (depois das eleições)

O que se torna evidente é que o tempo codificado pelo futuro do subjuntivo na encaixada não pode estar acima do tempo futuro da matriz. A natureza dessa restrição inerente ao futuro do subjuntivo ainda deve ser investigada. Ferreira (2018) propõe que, sendo um tempo referencial, o futuro do subjuntivo deve submeter-se ao princípio de Upper Limit Constraint (ULC) sugerido por Abusch (1997). O autor explica que, segundo a ULC, a denotação de um núcleo temporal não pode suceder o tempo local de avaliação. Assim, segundo Ferreira (2018), se assumirmos que o operador de futuro da matriz desloca o tempo de avaliação do momento de fala para o momento do evento da oração principal, 
teríamos uma explicação para a restrição observada: como um tempo referencial, o futuro do subjuntivo é posterior ao momento de fala, mas anterior ao tempo da matriz em função da ULC. Para os fins desta pesquisa, é suficiente termos evidências para a generalização do futuro do subjuntivo como um tempo referencial não-passado, concomitante ou posterior ao tempo de fala, apontando para um intervalo de tempo simultâneo ou anterior ao tempo da matriz, nunca posterior a ele.

\subsection{Conclusão}

Salientamos no início deste capítulo que boa parte das pesquisas sobre o modo subjuntivo se concentra em sua oposição com o indicativo, sem grande destaque às questões de tempo. Consideramos que essas questões podem ser particularmente interessantes para o estudo e a descrição de uma língua como o português, que conta não apenas com uma forma pretérita e uma forma presente do subjuntivo, mas também uma forma futura, não produtiva em outras línguas. Passamos em revisão os contextos de distribuição dos tempos do modo subjuntivo em português, destacando que a forma pretérita está disponível para todos os ambientes de uso do subjuntivo, mas que presente e futuro são mutuamente excludentes, competindo entre si, a não ser em contexto de orações relativas. Em outras palavras, contextos que requerem ou permitem o uso do presente do subjuntivo são agramaticais com o futuro do subjuntivo e vice-versa, com exceção das orações relativas, em que ambos os tempos são possíveis em ambientes idênticos.

Relembramos dois estudos que abordam o futuro do subjuntivo a partir de seus contrastes com o presente do subjuntivo, já discutidos no capítulo 1: tanto Comrie e Holmback (1984) quanto Marques (2010) não consideram que a diferença entre eles seja de natureza temporal. Em outras palavras, para eles, o futuro do subjuntivo não indicaria maior 'futuridade' do que o presente. Citamos também a proposta de Ferreira (2018), a qual, com base em uma teoria referencial do tempo (Partee, 1973), propõe que o futuro do subjuntivo é um tempo referencial futuro, apontando para um intervalo de tempo futuro em relação ao tempo de fala. Nessa linha, assumimos a descrição do futuro do subjuntivo como um tempo referencial não-passado, uma vez que ele toma o momento de fala como referência, descrevendo uma situação concomitante ou posterior a ele, nunca anterior. Vimos também que o intervalo de tempo referenciado pelo futuro do subjuntivo pode estar ligado ao tempo presente da matriz, caso em que os dois tempos são concomitantes, ou pode buscar sua referência no contexto (linguístico ou extralinguístico), quando então o tempo subordinado é anterior ao tempo subordinante. Salientamos que, de toda forma, o intervalo de tempo denotado pelo futuro do subjuntivo nunca pode ser posterior ao tempo da oração principal, restrição que não se verifica em sua contraparte indicativa. O que motiva essa restrição é objeto para pesquisas futuras. Para a discussão deste capítulo, nos 
valemos também do conceito de tempo de tópico (TT) proposto por Klein (1994, 2009), descrito pelo autor como o momento sobre o qual algo é falado, propondo que o futuro do subjuntivo está sempre relacionado a um tempo de tópico relevante no contexto linguístico ou extralinguístico. Manteremos o conceito de tempo de tópico em vista ainda para o próximo e último capítulo, em que trataremos de questões aspectuais que parecem dar boas pistas para a distinção entre as formas presente e futuro do subjuntivo em orações relativas. 


\section{Capítulo 4}

\section{Aspecto}

\subsection{Introdução}

Menos ainda do que questões temporais, trabalhos que tratam das formas do modo subjuntivo raramente incluem noções de aspecto de maneira ostensiva. Como vimos no capítulo anterior, por exemplo, Marques (2010) faz diferença entre predicados estativos e não-estativos ao tratar dos contrastes entre presente e futuro do subjuntivo, mas apenas para relacioná-los à orientação temporal de sentenças com uma ou outra forma. Comrie e Holmback (1984), por sua vez, analisam apenas sentenças com predicados estativos, como em (189), quando se propõem a determinar uma generalização para o significado do futuro do subjuntivo em contraste com o presente do subjuntivo, casos em que a diferença entre eles parece pouco evidente, o que poderia justificar apoiar sua distinção em outros elementos da sentença, como a (in)definitude do DP antecedente, caminho de análise escolhido pelos autores.

(189) a. João quer sair com uma mulher que seja rica.

b. João quer sair com a mulher que for rica.

Como vimos, eles defendem que descrições indefinidas do antecedente levam ao uso do presente do subjuntivo, enquanto descrições definidas determinam o uso do futuro. No entanto, sentenças como as exemplificadas em (190b) evidenciam que, mesmo com uma descrição definida, o futuro do subjuntivo pode parecer pouco aceitável, contrariamente ao previsto pela generalização de Comrie e Holmback (1984).

(190) a. João vai contratar uma secretária que fale inglês.

b. ?João vai contratar a secretária que falar inglês.

Já se tivermos uma oração subordinada com predicado não-estativo, o contraste entre presente e futuro do subjuntivo parece se evidenciar, mesmo que tenhamos um mesmo tipo de DP antecedendo a oração relativa. 
(191) a. ?João votará em candidatos que visitem São Paulo durante a campanha

b. João votará em candidatos que visitarem São Paulo durante a campanha

A explicação para isso pode estar ligada a questões aspectuais relacionadas com o futuro do subjuntivo, de forma que acreditamos que uma análise de dados mais variados, tomando noções de aspecto lexical em perspectiva, pode contribuir sensivelmente para uma generalização mais precisa, ou ao menos mais abrangente, dessa forma verbal, em especial para caracterizá-la em sua oposição ao presente do subjuntivo.

Para além de questões de aspecto lexical, uma vez que estamos defendendo a proposta de que o futuro do subjuntivo deve ser considerado um tempo referencial, convém discutir também, ainda que em caráter preambular, de que forma tempo e aspecto gramatical interagem nesse contexto. Como veremos, as categorias de tempo e aspecto se relacionam de maneira sutil, muitas vezes codificadas sob uma mesma morfologia. Para o futuro do subjuntivo, apesar de não haver marcação morfológica que diferencie os aspectos perfectivo e imperfectivo, à oposição do que acontece, por exemplo, com os tempos pretéritos do português, em alguns casos essas interpretações parecem estar disponíveis de outra forma. Para explorar essas ideias, este capítulo se organiza da seguinte maneira. Na seção 4.2 apresentaremos o referencial teórico que guiará nossa análise, detalhando os conceitos de aspecto gramatical e de aspecto lexical. Na seção 4.3, retomaremos o diálogo com a proposta de Comrie e Holmback (1984) para o futuro do subjuntivo, para então procedermos à análise dos dados à luz do quadro teórico apresentado.

\subsection{Referencial teórico}

Neste capítulo continuaremos a apoiar nossa análise na teoria de tempo proposta por Klein (1994, 2009). Nos basearemos, portanto, nos conceitos de tempo de fala (TU), momento em que o enunciado é expresso; tempo da situação (Tsit), momento em que a situação ocorre; tempo do tópico (TT), momento sobre o qual algo é falado; e em especial na relação entre Tsit e TT, a partir da qual se define o aspecto gramatical perfectivo ou imperfectivo do predicado. A essas noções de aspecto gramatical se relacionam também questões de aspecto lexical (Aktionsart), classificação que subdivide os verbos de acordo com a propriedades temporais das situações que eles descrevem. Essas definições aqui elencadas serão detalhadas a seguir.

\subsubsection{Aspecto gramatical: tempo da situação (Tsit) e tempo de tópico (TT)}

Assim como o tempo, o aspecto também é uma categoria gramatical do verbo. Tradicionalmente, o aspecto verbal é definido como as diferentes formas em que se pode apresentar 
a constituição temporal interna de determinada situação. Assim, os diferentes aspectos são maneiras distintas de se 'ver' uma mesma situação. Uma distinção bastante comum é aquela entre os aspectos perfectivo e imperfectivo, exemplificados nas sentenças (192a) e (192b), respectivamente. Em (192a) temos uma situação em andamento, enquanto em (192b) a situação é apresentada como completa.

(192) a. Maria abria a porta.

b. Maria abriu a porta.

São diversas as tentativas de tornar mais precisa a caracterização do contraste entre os aspectos perfectivo e imperfectivo em relação à forma como eles apresentam diferentes pontos de vista acerca de uma situação. Além da já citada distinção entre uma situação completa e uma situação em curso, também se considera que a situação é vista de fora ou vista de dentro, ou com limites definidos ou indefinidos.

Klein $(1994,2009)$ chama a atenção para o fato de que, de acordo com acepções mais tradicionais, o aspecto não é considerado em sua relação com um determinado momento. Ao contrário da categoria de tempo verbal, que relaciona a situação (ou tempo do tópico, como assumimos no capítulo anterior) ao momento de fala, o aspecto não é presumidamente tempo-relacionado. Ele apenas apresenta um ponto de vista particular acerca da situação descrita na sentença, independentemente do tempo. O autor argumenta, no entanto, que o aspecto também deve ser considerado em sua relação com o tempo, à medida que uma situação 'completa' ou 'em andamento' só faz sentido se relacionada a um determinado momento.

Consideremos o exemplo em (193). É coerente dizer que a situação descrita estava completa, por exemplo, às duas da tarde. Trinta minutos antes ela talvez estivesse em curso ou nem mesmo iniciada. Trinta minutos depois, essa mesma situação pode já não estar acontecendo.

Maria assou um bolo.

Dessa forma, a definição que propõe que 'o aspecto perfectivo apresenta uma situação como completa' pode ser revista para algo como 'o aspecto perfectivo apresenta uma situação como completa em um determinado tempo T'. Da mesma maneira, podemos dizer que 'o aspecto imperfectivo apresenta uma ação em andamento em determinado tempo T'. A noção de (in)completude de uma situação depende, então, do momento sobre o qual algo é falado, ou seja, do tempo de tópico (TT). Assim, Klein (1994, 2009) sugere que o aspecto é determinado pela relação entre Tsit (o tempo da situação) e TT (o tempo do tópico), de forma que o aspecto perfectivo pode ser definido como aquele em que Tsit está contido em TT (194a), enquanto para o aspecto imperfectivo, TT está contido em Tsit (194b). 
(194) a. Maria assou um bolo.

b. Maria estava assando um bolo.

A relação Tsit x TT será retomada na seção 4.3. Antes, procederemos à exposição da classificação proposta por Vendler (1957) para agrupar os verbos de acordo com as características inerentes das situações que eles descrevem.

\subsubsection{Aspecto lexical (Aktionsart)}

Vimos anteriormente duas categorias gramaticais do verbo: tempo e aspecto. No entanto, a temporalidade pode estar também codificada no léxico. Nesse sentido, o Aktionsart corresponde à forma como um verbo se estrutura de acordo com as propriedades temporais das situações - qualquer estado, evento, processo ou ação - que ele descreve. A tradicional classificação de Vendler (1957) propõe quatro categorias de verbos (estados, atividades, accomplishments e achievements), classificadas a partir da presença ou ausência de traços de dinamicidade, duratividade e telicidade. Uma situação dinâmica marca algum tipo de mudança, em oposição a situações estáticas, que não tem mudanças internas. Uma situação durativa se desenvolve em um intervalo de tempo, em oposição a situações não durativas, as quais acontecem em um instante. Por fim, uma situação télica tem um ponto de término ou limite bem definido, em oposição a situações atélicas, as quais não culminam em um ponto final.

Estados denotam situações não dinâmicas, que se mantém inalteradas. São durativas e atélicas. Exemplos de estados são verbos como ter, saber e ser. São considerados homogêneos, ou seja, se x sabe y, por exemplo, isso é verdadeiro para qualquer subintervalo de tempo.
a. Maria é feliz.
b. Maria sabe inglês.

Atividades também são situações durativas, mas, ao contrário dos estados, são dinâmicas, apontando para algum tipo de mudança interna. Também não culminam em um ponto final, sendo por isso classificadas como atélicas.

a. João correu.

b. João dirigiu o carro.

Accomplishments também são dinâmicos e durativos como as atividades, mas, ao contrário dessas, culminam em um ponto final. São, portanto, considerados télicos. 
(197) a. João desenhou um círculo.

b. A neve derreteu.

Achievements tem as mesmas características de um accomplishment, com a exceção de que são eventos instantâneos, ou seja, sem duração interna.

(198) a. João caiu.

b. Maria encontrou as chaves.

Comrie (1976) acrescenta à lista ainda a categoria dos verbos semelfactivos. Assim como os achievements, verbos semelfactivos são pontuais, não durativos. A diferença entre eles é que achievements são télicos, ou seja, culminam em um ponto final, enquanto os semelfactivos são atélicos.

(199) a. João bateu à porta.

b. João espirrou.

Em resumo, considerando a classificação exposta, há uma categoria estativa, a dos verbos de estado (não dinâmicos, durativos e télicos), e quatro categorias não-estativas, as que subdividem os verbos em atividade (dinâmicos, durativos e atélicos), accomplishment (dinâmicos, durativos e télicos), achievement (dinâmicos, pontuais e télicos) e semelfactivos (dinâmicos, pontuais e atélicos). Para a discussão que iremos propor na próxima seção, nos basta a distinção entre os verbos estativos, os que não apresentam fases internas e mudança ao longo do tempo, e os não-estativos (ou eventivos), independentemente de suas subdivisões em outras classificações mais específicas.

Neste ponto, é importante salientarmos alguns pontos sobre a interação entre predicados estativos e não-estativos e o aspecto imperfectivo no caso de sentenças no passado em português brasileiro.

Em (200) temos um predicado não-estativo. Nesses casos, o aspecto imperfectivo em (200a) gera uma leitura de habitualidade passada. A leitura imperfectiva, de situação em curso, fica mais evidente se tivermos uma forma progressiva como em (200b).

(200) a. Maria dormia.

b. Maria estava dormindo.

Em outras palavras, ainda que essa leitura também esteja disponível para (201a), a forma mais natural de referenciá-la está em (201b).

(201) a. Maria dormia quando João chegou.

b. Maria estava dormindo quando João chegou. 
Já com predicados estativos como em (202), essa diferença parece não marcada. Apesar de (202b) também estar disponível, a forma perfectiva em (202a) é suficiente para a leitura de situação em curso à qual nos referimos acima.

(202) a. Maria morava em Londres quando se casou.

b. Maria estava morando em Londres quando se casou.

Veremos ao final deste capítulo como essa interação acontece também no caso do futuro do subjuntivo. Por ora, passaremos a uma breve comparação entre presente e futuro do subjuntivo com base na estatividade ou não-estatividade do predicado a partir do que foi discutido nesta subseção e retomando também a noção de tempo de tópico introduzida no capítulo anterior.

\subsection{O futuro do subjuntivo e a leitura aspectual do pre- dicado}

Conforme já discutido até aqui, Comrie e Homlback (1984) não consideram que exista diferença temporal entre presente e futuro do subjuntivo, ambos denotando referência temporal não passada. Para os autores, a diferença entre eles estaria associada à maior definitude do futuro em relação ao presente, o presente combinando-se a descrições indefinidas (203a) e (204a) e o futuro, a descrições definidas (203b) e (204b).

(203) a. José quer sair com uma mulher que tenha muito dinheiro.

b. José quer sair com a mulher que tiver muito dinheiro.

(204) a. José quer sair com uma mulher que tenha olhos azuis.

b. José quer sair com a mulher que tiver olhos azuis.

No entanto, vimos também que presente e futuro do subjuntivo podem ambos se combinar a descrições definidas e indefinidas, bem como a outros tipos de DPs e NPs, como nomes nus e quantificados, conforme exemplificado nas sentenças abaixo. Nessas condições, não podemos basear a distinção entre presente e futuro do subjuntivo apenas na definitude (ou indefinitude) do elemento que antecede a oração relativa.

(205) a. José quer sair com a mulher que tenha olhos azuis.

b. José quer sair com a mulher que tiver olhos azuis. 
(206) a. José quer sair com uma mulher que tenha muito dinheiro.

b. José quer sair com uma mulher que tiver muito dinheiro.

(207) a. José quer sair com mulheres que tenham muito dinheiro.

b. José quer sair com mulheres que tiverem muito dinheiro.

(208) a. José quer sair com qualquer mulher que tenha muito dinheiro.

b. José quer sair com qualquer mulher que tiver muito dinheiro.

(209) a. José quer sair com alguma mulher que tenha muito dinheiro.

b. José quer sair com alguma mulher que tiver muito dinheiro.

Tendo isso em vista, acreditamos que é interessante explorar o contraste entre essas duas formas de subjuntivo baseando-nos em outros fatores que não o tipo de $\mathrm{DP} / \mathrm{NP}$ antecedente, como o tipo de predicado constante na oração subordinada. No decorrer desta seção, vamos argumentar que, de fato, não existe agramaticalidade tão categórica quando se trata do contraste entre presente e futuro do subjuntivo em orações relativas e que, principalmente quando há predicados estativos na subordinada, esse mesmo contraste parece pouco relevante. No entanto, veremos que ele parece se tornar mais evidente quanto mais evidenciar-se, também, o tempo de tópico com o qual o intervalo de tempo denotado pelo futuro do subjuntivo se relaciona. Veremos como esses fatores interagem também em caso de predicados não-estativos.

\subsubsection{O futuro do subjuntivo com predicados estativos}

Predicados estativos são aqueles que apresentam situações homogêneas, que não progridem, não envolvendo processos que se desenvolvem no tempo. Nesses casos, como já apontado, a diferença entre presente e o futuro do subjuntivo, se ela existe, é pouco clara. Podemos dizer que, ainda que se possa expressar preferência por uma ou outra, ambas as sentenças que formam os pares abaixo são gramaticais:

(210) a. João vai contratar qualquer candidato que saiba inglês.

b. João vai contratar qualquer candidato que souber inglês.

(211) a. João vai demitir os funcionários que não sejam pontuais.

b. João vai demitir os funcionários que não forem pontuais. 
No capítulo anterior, discutimos as relações de tempo que o futuro do subjuntivo estabelece: ele descreve uma situação concomitante ou posterior ao momento de fala, a qual pode ser também concomitante à situação descrita na oração principal ou anterior a ela, nunca posterior. Vimos que essas noções se tornam mais claras se consideramos a relação do intervalo de tempo referenciado pelo futuro do subjuntivo com um determinado tempo de tópico, o momento sobre o qual algo é falado, saliente no contexto. De fato, se controlarmos as condições da sentença de forma a evidenciar o tópico, mais natural parece a opção com o futuro do subjuntivo em comparação com o presente.

(212) a. ?João vai demitir os funcionários que não sejam pontuais. (a partir de hoje)

b. João vai demitir os funcionários que não forem pontuais. (a partir de hoje)

Em outro exemplo, podemos imaginar um contexto em que João vai contratar o candidato que mostrar mais habilidades com a língua inglesa durante um processo seletivo, considerado aqui o tempo de tópico.

(213) a. ?João vai contratar o candidato que saiba inglês melhor.

b. João vai contratar o candidato que souber inglês melhor.

Em (214), em que temos uma situação descrita pelo futuro do subjuntivo simultânea ao tempo de fala e também ao tempo da oração principal, o tópico fica menos evidenciado, sendo pouco saliente, também, o contraste entre presente e futuro do subjuntivo.

(214) a. Maria quer ajudar candidatos que tenham a ficha limpa.

b. Maria quer ajudar candidatos que tiverem a ficha limpa.

Já em (224a), a versão com o presente do subjuntivo parece, de fato, não aceitável se considerarmos o tempo de tópico como o momento da campanha política que ainda vai se iniciar. Nesse contexto, só a versão com o futuro do subjuntivo parece boa. A leitura saliente para o presente é a de que a campanha já está em curso, o que não condiz com o contexto proposto.

(215) a. \#Maria vai votar no candidato que tenha mais tempo de televisão.

b. Maria vai votar no candidato que tiver mais tempo de televisão.

A partir dos exemplos acima expostos fique explicitada a contribuição do tempo de tópico para a interpretação dessas sentenças, mesmo em caso de predicados estativos, em que as diferenças entre presente e futuro do subjuntivo pareciam, em um primeiro exame, pouco evidentes. Veremos a seguir como isso se dá, também, com predicados não-estativos. 


\subsubsection{O futuro do subjuntivo com predicados não-estativos}

Predicados não-estativos são aqueles que apresentam situações dinâmicas. Nesse caso, o contraste entre presente e futuro do subjuntivo parece naturalmente mais saliente, mas também pode se tornar mais claro a partir do conceito de tempo de tópico que exploramos até aqui.

Tomemos como exemplo as sentenças em (216). Informalmente, poderíamos dizer que em (216a) estamos nos referindo a uma característica própria do candidato, não fixada no tempo, enquanto em (216b) parece ser o caso de estarmos nos referindo a uma situação no futuro, como os discursos que serão feitos durante o período que compreende a campanha eleitoral.

(216) a. João vai votar em candidatos que façam bons discursos.

b. João vai votar em candidatos que fizerem bons discursos.

Assim, supondo um contexto em que estejamos falando de uma eleição ainda por acontecer, cuja campanha deve se iniciar nos próximos dias, em (216a) temos uma leitura habitual presente do predicado na encaixada, expressando uma situação que acontece de forma costumeira, enquanto em (216b) há uma leitura episódica futura em relação ao intervalo de tempo relevante. Em (216a), os candidatos em quem João vai votar têm a característica de serem bons oradores em geral, enquanto em (216b), eles farão bons discursos em um intervalo de tempo específico no futuro (em outras palavras, no tempo do tópico, momento sobre o qual algo é falado). Atualizando as sentenças como em (217), essas interpretações ficam mais evidentes.

(217) a. João vai votar em candidatos que façam bons discursos (sempre).

b. João vai votar em candidatos que fizerem bons discursos (durante a campanha).

Em (218) e (219), por exemplo, em que se tem em evidência um tempo de tópico futuro, a versão com o presente do subjuntivo é bastante degradada em relação àquela com o futuro do subjuntivo.

(218) a. ? João vai contratar os candidatos que acertem todas as questões do teste. (durante um processo seletivo específico)

b. João vai contratar os candidatos que acertarem todas as questões do teste. (durante um processo seletivo específico) 
(219) a. ?João vai demitir os funcionários que cheguem atrasados para a reunião de amanhã.

b. João vai demitir os funcionários que chegarem atrasados para a reunião de amanhã.

Vemos, portanto, que também em caso de predicados não-estativos, o tempo de tópico evidente é relevante para que o uso do futuro do subjuntivo seja lícito, enquanto o presente dos subjuntivo, nesses contextos, parece indicar habitualidade.

Apesar de não ser objetivo desta dissertação aprofundarmo-nos em questões relativas ao presente do subjuntivo, acreditamos ser importante lidarmos com os dados aqui apresentados, ainda que em abordagem de caráter preliminar, uma vez que sua alternância com o futuro do subjuntivo em contexto de orações relativas é facilmente verificável, ao mesmo tempo em que os trabalhos que abordam a questão nos parecem pouco ou parcialmente conclusivos. Nesse sentido, as questões aspectuais aqui apontadas indicam um caminho plausível para análise do contraste entre essas duas formas.

Voltando nossa atenção ao nosso objeto de análise em si, vamos retomar os conceitos apresentados no início deste capítulo para verificar brevemente de que maneira se dá a interação entre aspecto e tempo futuro do subjuntivo em orações relativas.

\subsubsection{O futuro do subjuntivo e o aspecto gramatical}

No capítulo anterior argumentamos a favor da ideia de que o futuro do subjuntivo deve ser tratado como um tempo referencial, ancorado ao momento de fala, apontando para um intervalo de tempo não-passado. O futuro do subjuntivo, no entanto, não tem uma morfologia específica para a diferenciação de aspecto como o passado em (220), que apresenta marcações de aspecto perfectivo e imperfectivo evidentes. Em (220a) temos o aspecto imperfectivo, em que Tsit inclui TT, veiculando ideia de situação em andamento. Em (220b), por sua vez, temos o aspecto perfectivo, em que Tsit está incluso em TT, quando a situação é considerada completa em relação a um momento determinado.
a. Maria estava abrindo a porta.
b. Maria abriu a porta.

No caso do futuro do subjuntivo, os aspectos perfectivo e imperfectivo não são morfologicamente marcados. Em outras palavras, podemos dizer que as categorias de tempo e aspecto compartilham uma mesma forma. Assim, o que aqui foi chamado de futuro do subjuntivo apenas para referir-se a tempo veicula também informação de aspecto perfectivo ou perfectivo, a depender da sentença em questão.

Como já especificado, os tempos pretéritos tem marcação aspectual específica, com o perfectivo em (221a) e (222a) e o imperfectivo em (221b) e (222b). 
(221) a. Maria fez um bolo.

b. Maria fazia um bolo.

(222) a. Maria morou na Inglaterra.

b. Maria morava na Inglaterra.

Além disso, vimos que com predicados não-estativos, a forma perfectiva simples (223a) tem uma leitura saliente habitual, enquanto a forma progressiva (223b) é a maneira mais natural de indicar uma situação em curso.

(223) a. Maria fazia um bolo.

b. Maria estava fazendo um bolo.

Vejamos como o futuro do subjuntivo em orações relativas se comporta em relação a essas questões. Em primeiro lugar, para predicados estativos, parece não haver especificação de aspecto. Isso fica visível se compararmos as sentenças no futuro do subjuntivo com sua 'paráfrase' no passado.

(224) a. João vai votar nos candidatos que tiverem mais tempo de televisão.

b. João votou em candidatos que tinham/tiveram mais tempo de televisão.

Em (224), vemos que a forma no futuro do subjuntivo pode ter um correspondente perfectivo ou imperfectivo no passado, sem alterações significativas de interpretação. O mesmo se dá em (225).

(225) a. João vai contratar os candidatos que souberem responder todas as questões do teste.

b. João contratou os candidatos que sabiam/souberam responder todas as questões do teste.

Com predicados não-estativos, no entanto, vemos que a leitura aspectual pode variar. Em (226), dadas as condições da sentença, a leitura perfectiva, em que o tempo da situação está contido no tempo do tópico, é única disponível para o futuro do subjuntivo em (226a). Podemos compará-la também a sua contraparte passada (226b).

(226) a. João vai votar no candidato que visitar São Paulo primeiro.

b. João votou no candidato que visitou São Paulo primeiro.

O mesmo se dá em (227): 
(227) a. João vai demitir os funcionários que dormirem na reunião de amanhã.

b. João demitiu os funcionários que dormiram na reunião ontem.

Já em (228), temos um exemplo em que o o futuro do subjuntivo combinado a um predicado não-estativo pode ter leitura imperfectiva.

(228) a. João vai demitir os funcionários que dormirem nas reuniões.

b. João demitiu os funcionários que dormiam nas reuniões.

Neste caso, assim como descrevemos para o passado, o futuro do subjuntivo em (228a) parece apontar para uma interpretação habitual, da mesma forma que sua versão pretérita em (228b).

Também observamos anteriormente que, para sentenças no passado, a melhor maneira de marcar uma situação em curso em caso de predicados não-estativos é com uma forma progressiva. O mesmo se pode observar também com o futuro do subjuntivo em (229a).

(229) a. João vai demitir os funcionários que estiverem dormindo em serviço. (agora).

b. João demitiu os funcionários que estavam dormindo em serviço. (ontem)

As sentenças abaixo fornecem ainda um outro exemplo:

(230) a. João vai demitir os funcionários que estiverem falando mal dele.

b. João demitiu os funcionários que estavam falando mal dele.

Em resumo, parece ser o caso de não haver marcação relevante de aspecto para o futuro do subjuntivo em orações relativas com predicados estativos, apenas com predicados não-estativos. Nesse contexto, assim como acontece com as formas pretéritas, a forma progressiva se apresenta como a melhor maneira de fazer diferença entre uma situação habitual e uma situação em curso.

Esses apontamentos não tem a pretensão de categorizar ou esgotar a questão. Pretendemos neste ponto, a princípio, chamar atenção a noções aspectuais relacionadas ao subjuntivo, em geral ignoradas em estudos precedentes, e delinear a partir daí um possível caminho para análises futuras.

\subsection{Conclusão}

Iniciamos este capítulo reforçando a escassez de estudos sobre as formas do modo subjuntivo que considerem também noções de aspectos relacionadas a elas. Relembramos o estudo de Marques (2010), que faz diferença entre predicados estativos e não-estativos em orações relativas apenas para comparar a informação temporal vinculada por presente 
e futuro do subjuntivo. Retomamos também Comrie e Holmback (1984), o estudo mais relevante acerca do futuro do subjuntivo, o qual, apesar de sua evidente contribuição, não apresenta um conjunto variado de dados, uma vez que trata apenas de sentenças com predicados estativos. Vimos que, uma vez considerados também predicados eventivos, passamos a ter uma visão melhor do nosso objetivo de pesquisa, tornando mais claros os contrastes entre presente e futuro do subjuntivo e possibilitando uma descrição mais detalhada do futuro do subjuntivo em si.

Observamos que o contraste entre presente e futuro do subjuntivo em orações relativas pode parecer pouco evidente, em especial quando há um predicado estativo na subordinada, mas que as diferenças entre eles se evidenciam conforme se torna claro o tempo de tópico ao qual o futuro do subjuntivo se relaciona. Argumentamos também que o futuro do subjuntivo em orações relativas deve ser considerado um tempo referencial não-passado sem marcação aspectual em sua morfologia. No caso de predicados estativos, perfectividade e imperfectividade parecem não marcados. No caso de predicados não-estativos, a leitura aspectual perfectiva é possível, a depender da sentença, enquanto a leitura imperfectiva pode indicar tanto habitualidade, quando há a forma simples do verbo, quanto situação em curso, quando há a forma progressiva.

Por fim, salientamos que o conteúdo deste capítulo não tem a pretensão de uma análise categórica e definitiva das questões apresentadas, mas espera-se poder contribuir para a descrição do futuro do subjuntivo levando em consideração fatores até então preteridos em análises anteriores. 


\section{Capítulo 5}

\section{Considerações finais e questões em aberto}

Esta pesquisa trata de noções gerais acerca do futuro do subjuntivo em orações relativas levando em consideração questões de modo, tempo e aspecto com o objetivo de apresentar descrição e análise dessa forma verbal. Apesar de seu uso patente em orações adverbiais temporais e condicionais, delimitamos nosso foco em orações relativas por ser esse o único ambiente em que o futuro do subjuntivo pode ser alternar com o presente do subjuntivo, considerado seu competidor no sistema verbal do português.

No capítulo 1, tratamos de estudos anteriores que se dedicam à descrição e análise do nosso objeto, em especial os desenvolvidos por Marques (2010) e Comrie e Holmback (1984), ambos explorando o contraste entre presente e futuro do subjuntivo e concluindo que a diferença entre eles não é de natureza temporal, o que difere sensivelmente da proposta que desenvolvemos em seguida.

No capítulo 2, baseando-nos em Quer (1998, 2008), abordamos questões de modo, em especial o contraste entre os modos indicativo e subjuntivo, concluindo que o indicativo em orações relativas pode apontar para uma leitura atributiva ou não atributiva do elemento que antecedente, enquanto para o subjuntivo apenas a leitura atributiva está disponível. Passamos em revisão também as características das orações relativas com subjuntivo, descrevendo em especial o licenciamento do futuro do subjuntivo nesses ambientes, o qual só é possível mediante a presença de um tempo futuro na matriz ou de algum predicado que de alguma forma desloque a referência temporal para o futuro, como querer.

No capitulo 3, dedicado a questões temporais, partindo de Ferreira (2018), que propõe que o futuro do subjuntivo deve ser considerado um tempo referencial futuro, argumentamos por considerá-lo um tempo referencial não-passado, uma vez que ele estabelece relação de posteridade com o momento de fala em alguns casos, mas de concomitância em outros, nunca de anterioridade. Além disso, o futuro do subjuntivo estabelece relação também com o tempo da matriz, a qual pode ser de simultaneidade ou de anterioridade, 
nunca de posteridade. Argumentamos também que o intervalo de tempo referenciado pelo futuro do subjuntivo está sempre relacionado a um tempo de tópico (o momento sobre o qual algo é falado, conceito proposto por Klein $(1994,2009)$ ), saliente no contexto (linguístico ou extralinguístico).

No capítulo 4, abordando questões aspectuais, voltamos à comparação entre presente e futuro do subjuntivo, apontando que a diferença entre eles se torna mais clara à medida em que se evidencia também o tempo de tópico acima citado, seja em casos de predicado estativo, em que o contraste entre presente e futuro parece às vezes pouco importante, seja em casos de predicado não-estativo, em que essas diferenças parecem mais claras. Vimos também de que maneira os aspectos perfectivo e imperfectivo interagem com o tempo futuro do subjuntivo, uma vez que não há marcação morfológica de aspecto.

Em resumo, a proposta desta pesquisa foi contribuir com uma generalização para o futuro do subjuntivo, especificamente em contexto de orações relativas. Detalhamos ao longo deste trabalho como o futuro do subjuntivo requer sempre um tempo futuro ou uma referência futura na matriz para que seja licenciado em orações relativas e que o subjuntivo em si contribui nesses casos conferindo sempre uma leitura não-atributiva ao antecedente. Propusemos também que o futuro do subjuntivo deve ser considerado um tempo referencial, apontando para um intervalo de tempo não-passado, restrito entre o tempo de fala e o tempo da matriz. Um primeiro movimento foi feito também em sentido de caracterizá-lo quanto a suas questões aspectuais, destacando-se que o futuro do subjuntivo não apresenta marcação morfológica de aspectos perfectivo e imperfectivo.

Sabemos, entretanto, que há ainda muito a ser explorado. Os passos seguintes apontam para a possibilidade de se verificar se a análise proposta aqui se estende aos outros domínios em que encontramos o futuro do subjuntivo, nomeadamente orações subordinadas adverbiais introduzidas por se e quando e orações relativas sem antecedentes. Há ainda que se detalhar a natureza da restrição que não permite que a situação descrita na sentença subordinada com o futuro do subjuntivo seja localizada posteriormente à situação da oração principal, restrição que não se verifica em sua contraparte indicativa. As discussões sobre o papel do subjuntivo - para além de conferir uma interpretação atributiva ao DP/NP antecedente - também podem ser aprofundadas. De todo maneira, espera-se que este trabalho possa contribuir com noções gerais a respeito dessa forma subjuntiva tão peculiar, agregando noções não só de modo, mas também de tempo e aspecto até então pouco exploradas em trabalhos anteriores. 


\section{Referências bibliográficas}

ABUSCH, D. Sequence of tense and temporal de re. Linguistics and Philosophy, 20(1):1-50, 1997.

ANAND, P.; HACQUARD, V. Epistemics and attitudes. Semantics and Pragmatics, 6(8):1-59, 2013.

BECHARA, Evanildo. Moderna gramática portuguesa. São Paulo: Nacional, 1980 [1968/2009].

BELL, A. "El modo en español: consideración de algunas propuestas recientes". In Indicativo y subjuntivo (Ignacio Bosque, editor), pp. 81-105. Madrid: Taurus Universitaria, 1990.

BYBEE, J. Morphology: A study of the relation between meaning and form. John Benjamins Publishing, 1985.

BYBEE, J. TERREL T. D. "Análisis semántico del modo en español”. In Indicativo y subjuntivo (Ignacio Bosque, editor), pp. 145-163. Madrid: Taurus Universitaria, 1990.

BYBEE, J, PERKINS, R, PAGLIUCA, W. The Evolution of Grammar: Tense, Aspect, and Modality in the Languages of the World. Chicago: University of Chicago Press. 1994.

CARLSON, G.. Reference to Kinds in English. University of Massachusetts at Amherst. Published 1980 by Garland Press, New York, 1977.

CEGAlLA, D. P. Novíssima gramática da lingua portuguesa. 46. ed. São Paulo: Companhia Editora Nacional, 2005[2008].

CHIERCHIA, Gennaro. Dynamics of meaning: Anaphora. Presupposition, and the Theory, 1995.

COMRIE, B.; HOLMBACK, H. The future subjunctive in Portuguese: a problem in semantic theory. International Review of General Linguistics (Língua) 63 (3-4), 213-253, 1984.

COMRIE, Bernard. Tense. Cambridge: Cambridge University Press, 1985. Aspect. Cambridge: Cambridge University Press, 1976.

CONDORAVDI, C. A. Descriptions in context. Routledge, 1994.

CUNHA, C.; CINTRA, L. Nova gramática do português contemporâneo de acordo com a nova ortografia. $5^{\mathrm{a}}$. ed. Rio de Janeiro: Lexikon, 2008. 
FARKAS, Donka. On the semantics of subjunctive complements. Romance languages and modern linguistic theory, 1992a, 69-104.

. On obviation. Lexical matters, 1992b, 1: 85-109.

FERREIRA, M. Estudos formais sobre a semantica nominal e verbal do português. Tese de Livre Docência — Universidade de São Paulo, São Paulo, 2018

FLEISCHMAN, S. The Future in Thought and Language: Diachronic Evidence from Romance. Cambridge: Cambridge University Press, 1982.

GIANNAKIDOU, A. The semantic licensing of NPIs and the Modern Greek subjunctive, Language and Cognition, 4, yearbook of the Research Group for Theoretical and Experimental Linguistics. University of Groningen, 1994.

et al. On the interpretation of null indefinite objects in Greek. Studies in Greek linguistics, 1997, 17: 141-155.

, A. Affective dependencies. Linguistics and Philosophy, 22(3):367-421, 1999.

The dependency of the subjunctive revisited: Temporal semantics and polarity. Lingua, 119(12):1883-908, 2009.

. Nonveridicality and mood choice: subjunctive, polarity, and time. In Musan, R. and Rathert, M., eds, Tense across Languages. Niemeyer, Tübingen, 2011.

. Evaluative subjunctive and nonveridicality. In Błaszczak, J., Giannakidou, A., Klimek-Jankowska, D., and Migdalski, K., eds, Mood, Aspect, Modality Revisited: New Answers to Old Questions, pages 177-217. University of Chicago Press, Chicago, IL, 2016.

GIANNAKIDOU, A. e MARI, A. Mixed veridicality and mood choice in complement clauses. Ms, University of Chicago, 2015.

GIORGI, A.; PIANESI, F. Tense and aspect: From semantics to morphosyntax. Oxford University Press on Demand, 1997.

GIVÓN, T. Functionalism and grammar. John Benjamins Publishing, 1995. , The genesis of syntactic complexity. John Benjamins, 2009.

GREVISSE, Maurice. Le Bon usage: grammaire française, avec des remarques sur la langue française d'aujourd'hui. 9e édition revue. Editions J. Duculot, 1969.

GROENENDIJK, Jeroen; STOKHOF, Martin. Dynamic predicate logic. Linguistics and philosophy, 1991, 14.1: 39-100.

GRYNER, H. A variação de tempo-modo e conexão nas orações condicionais do português. Tese de Doutorado. Universidade Federal do Rio de Janeiro, Rio de Janeiro, 1990.

HEIM, I. The semantics of definite and indefinite noun phrases. 1982.

, Presupposition projection and the semantics of attitude verbs. Journal of semantics, 1992, 9.3: 183-221.

, Comments on Abusch's theory of tense. In Kamp, H., editor, Ellipsis, Tense, and Questions, pp. 143-170. University of Amsterdam, Amsterdam, 1994 
HEIM, I; KRATZER, A. Semantics in generative grammar. Oxford: Blackwell, 1997.

HIRATA-VALE, F. B. M. Para uma interpretação condicional de construções temporais do português: contextos de uso. Alfa (ILCSE/UNESP), v. 52, p. 167-177, 2008.

HOOPER, J. B. On assertive predicates. In Syntax and Semantics 4 (P. Kimball, editor), pp. 91 - 124. New York: Academic Press, 1975

HOOPER, J. B. e THOMPSON S. A. "On the Applicability of Root Transformations," Linguistic Inquiry 4, 465-497, 1973.

HUNTLEY, Martin. The semantics of English imperatives. Linguistics and Philosophy, 1984, 7.2: 103-133.

JESUS, A. M. V. S. Aquisição do modo em orações completivas do português europeu: o papel dos traços de epistemicidade e veridicidade. 158 f. Dissertação (mestrado) Universidade de Lisboa, 2014.

JUSTINO, V. M. A distribuição e a expressão gramatical do futuro do conjuntivo no português de Moçambique. Dissertação de mestrado. Universidade de Lisboa, 2011.

KAMP, H. A theory of truth and semantic representation. Formal semantics-the essential readings, 1981, 189-222.

KAMP, H.; REYLE, U. From Discourse to Logic, volume 42 of Studies in Linguistics and Philosophy. 1993.

KLEIN, F. "Pragmatic constraints in distribution: the Spanish subjunctive" In Papers from the IIth regional meeting, pp. 353 - 65. Chicago Linguistic Society, 1975.

Restricciones pragmaticas sobre la distribución del subjuntivo en español.

In Indicativo y Subjuntivo (Ignacio Bosque, editor), pp 303 - 315. Madrid: Taurus Universitaria, 1990.

KLEIN, W. Time in language. Routledge, 1994.

, How time is encoded. The expression of time, 2009, 3: 1-43.

KRATZER, Angelika, et al. Modality. Semantics: An international handbook of contemporary research, 1991, 7: 639-650.

. More structural analogies between pronouns and tenses. In proceedings of SALT VIII, pp. 92-110. CLC Publications, 1998.

LANGACKER, R. W. Foundations of cognitive grammar, Vol. 1: Theoretical prerequisites. Stanford: Stanford University Press, 1987.

2009

Investigations in cognitive grammar. Berlin/New York: Mouton de Gruy-

Foundations of cognitive grammar, Vol. 2: Descriptive application. Stanford: Stanford University Press, 1991.

Cognitive grammar: A basic introduction. Oxford: Oxford University Press, 2008 
MACEDO, A. O uso do futuro do subjuntivo em português: regularização de uma forma verbal. Tese de Doutorado. Rio de Janeiro:Universidade Federal do Rio de Janeiro, 1980.

MARQUES, Rui. Sobre a semântica dos tempos do conjuntivo. Actas do XXV Encontro da Portuguesa de Linguística. Textos Seleccionados, APL, pp. 549-565, 2010.

On the system of mood in European and Brazilian Portuguese. Journal of Portuguese Linguistics,3.1, 89-109, 2004.

Sobre o valor dos modos conjuntivo e indicativo em português. Dissertação de Mestrado, Faculdade de Letras da Universidade de Lisboa, 1995.

MCCAWLEY, James D. Everything that linguists have always wanted to know about logic... but were ashamed to ask. University of Chicago Press, 1993.

MESQUITA, Roberto Melo. Gramática da língua portuguesa. $8^{\mathrm{a}}$. ed. São Paulo: Saraiva, 1999.

MOIGNET, G.; Systématique de la langue française; Paris; Klincksieck, 1981.

MONTAGUE, R.; On the Nature of Certain Philosophical Entities; The Monist 53, pp. 159 - 194. 1969.

MOREIRA LIMA-SALLES, H. M. "Infinitive clauses as substitutes for subjunctive clauses in Brazillian Portuguese", in A.T. Pérez-Leroux e Y. Roberge (orgs.), 153. Romance Linguistics: Theory and Acquisition, Selected Papers from the 32nd Linguistic Symposium on Romance Languages (LSRL). Amesterdão: John Benjamins, 197-208, 2003.

PARTEE, B. H. Some structural analogies between tenses and pronouns in English. The Journal of Philosophy, 1974, 70.18: 601-609.

PERINI, M. A. Gramática do português brasileiro: a língua do Brasil. Rio de Janeiro: Ed. Vozes, 2017.

, Sintaxe e semântica do futuro do subjuntivo. Revista de Ensaios de Linguística, Belo Horizonte, p. 20-43, 1978.

PIMPÃO, T. S. Uso variável do presente do subjuntivo. Tese (Doutorado em Linguística). Programa de Pós-graduação em Linguística, UFSC, Florianópolis, 2012.

PORTNER, Paul. Situation Theory and the Semantics of Propositional Expressions: University of Massachusetts at Amherst. 1992. PhD Thesis. Ph. D dissertation.

. Situation theory and the semantics of propositional expressions. 1993.

- _ - _ . The semantics of mood, complementation, and conversational force. Natural language semantics, 1997, 5.2: 167-212.

_____. Modality, Oxford Univeristy Press, 2009.

_-___. Mood, Oxford Univeristy Press, 2018.

QUER, J. Mood at the Interface. The Hague: Holland Academic Graphics, 1998. 
, Interpreting mood. Probus, 13(1), pp. 81-111. Retrieved 2 May. 2018, from doi:10.1515/prbs.13.1.81, 2008.

, Twists of mood: The distribution and interpretation of indicative and subjunctive. 2009.

REICHENBACH, H. Elements of Symbolic Logic. New York:Macmillan Company, 1947.

REIS, D. L. O domínio funcional do futuro do subjuntivo: entre temporalidade e modalidade. Tese (Doutorado em Linguística). Programa de Pós-graduação em Linguística, UFSC, Florianópolis, 2014.

SALTARELLI, Mario. Reference and mood in Italian. Linguistic studies in, 1974.

SATO, F. "Valeur modale du subjonctif en français contemporain"; in Le Français Moderne; vol. 42; pp. $34-41,1974$.

SOLANO-ARAYA, J. Modality in Spanish: An Account of Mood. PhD diss., University of Kansas. Ann Arbor: UMI, 1982

SANTOS, M. L. Semântica de condicionais e contexto. Tese de Doutorado. Programa de Pós-graduação em Linguística. UFSC, Florianópolis, 2006.

SANTOS, R. M. A. O uso variável do modo subjuntivo em estruturas complexas. 143 f. Dissertação (mestrado) - Universidade Estadual Paulista, Instituto de Biociências, Letras e Ciências Exatas, 2005.

SCHLENKER, P. A plea for monsters. Linguistics and Philosophy, 26:29-120, 2003.

SCHLENKER, P. The lazy Frenchman's approach to the subjunctive (specula- tions on reference to worlds and semantic defaults in the analysis of mood), 2005.

SCHLENKER, P. Indexicality and de se reports. In von Heusinger, K., Maien-born, C., and Portner, P., eds, Semantics: An International Handbook of Natural, Language Meaning, volume 2. de Gruyter, Berlin, 2011.

STALNAKER, R. Assertion. 1978.

STEN, H.. L'emploi des temps en portugais moderne. Det Kongelige Danske Videnskabernes Selskab. Historisk-fllosofiske Meddelelser. Kobenhavn: Munksgaard in Komm, 1973.

STOWELL, T. Syntax of tense. ms., UCLA, 1993.

VENDLER, Z. Verbs and Times, The Philosophical Review 66(2):143-160. ISSN 00318108, 1957.

VESTERINEN, R. Uma aproximação cognitiva ao modo conjuntivo [A cognitive approach to the subjunctive mood]. Revista Portuguesa de Humanidades: Estudos Linguísticos, 14(1), 151-174, 2010.

. O modo verbal em expressões impessoais com o verbo "ser" [The verbal mood in impersonal expressions with the verb "to be"]. Revue Romane, 47(1), 76-97, 2012 . 
- Finalidade e domínio: A forma verbal nas orações finais introduzidas por "para" [Purpose and dominion: The verbal form in purpose clauses introduced by "para"]. Studies in Hispanic and Lusophone Linguistics, 6(2), 351-375, 2013.

. Impersonals with "ser" ('to be') and the dominion of effective control. Language Sciences, 41, 143-152, 2014a.

. Extending the dominion of effective control: Its applicability to mood choice in Spanish and Portuguese. Cognitive Linguistics, 25(4), 583-616, 2014b

. The Portuguese future subjunctive. Review of Cognitive Linguistics. Published under the auspices of the Spanish Cognitive Linguistics Association, 2017, 15.1: 58-82.

VILLALTA, E. Spanish subjunctive clauses require ordered alternatives. In Jackson, B. and Matthews, T., eds, The Proceedings of SALT 10, pages 239-56. CLC Publications, Ithaca, NY, 2000.

. Context Dependence in the Interpretation of Questions and Subjunctives. PhD thesis, Tübingen, 2006.

. "Mood and Gradability: An Investigation of the Subjunctive Mood in Spanish," Linguistics and Philosophy 31, 467-522, 2008.

VON STECHOW, A. On the proper treatment of tense. In Proceedings of SALT, volume 5, pp. 362-386. Citeseer, 1995

YVON, H. Le subjoctif imparfait, mode de l'irréel; Le Français Moderne; vol. 15; pp. 6-16. 1947 